Portland State University

PDXScholar

Fall 1-5-2017

\title{
Charles A. Moose: Race, Community Policing, and Portland's First African American Police Chief
}

Douglas Jon Kenck-Crispin

Portland State University

Follow this and additional works at: https://pdxscholar.library.pdx.edu/open_access_etds

Part of the Law and Race Commons, and the United States History Commons Let us know how access to this document benefits you.

\section{Recommended Citation}

Kenck-Crispin, Douglas Jon, "Charles A. Moose: Race, Community Policing, and Portland's First African American Police Chief" (2017). Dissertations and Theses. Paper 3412.

https://doi.org/10.15760/etd.5310

This Thesis is brought to you for free and open access. It has been accepted for inclusion in Dissertations and Theses by an authorized administrator of PDXScholar. Please contact us if we can make this document more accessible: pdxscholar@pdx.edu. 
Charles A. Moose: Race, Community Policing, and Portland's First African American

Police Chief

\author{
by \\ Doug Kenck-Crispin
}

\begin{abstract}
A thesis submitted in partial fulfillment of the requirements for the degree of

\section{Master of Arts}

in

History
\end{abstract}

\author{
Thesis Committee: \\ Tim Garrison, Chair \\ Katrine Barber \\ David Johnson \\ Brian Renauer
}

Portland State University

2016 
(C) 2016 Doug Kenck-Crispin 


\begin{abstract}
In 1993, Charles Moose became Portland, Oregon's first black police chief. A nationally recognized student of the developing theories of community policing, Chief Moose's promotion was also hoped to help strengthen the diversity of the Portland Police Bureau. Ultimately, Portlanders were unable to look past Moose's public outbursts and demeanor and recognize his accomplishments. As a city, they missed an opportunity.
\end{abstract}

This thesis uses transcripts of speeches and policy papers to present some political history to the reader, but also letters to the mayor's office, letters to the editor and the like to consider the social history of 1990's Portland. Some specific touchpoints of Moose's administration are considered, including when he and his wife Sandy moved to the King Neighborhood, the Daniel Binns birthday party and the resulting march on Moose's home, his outburst at the City Council, and other examples of his legendary anger. Moose's role in gentrification, and the policies he created for the Portland Police Bureau to lead that charge will not be ignored. All the while, the context of Oregon's racist heritage is forefront in this paper.

By 1999, Charles Moose had left the bureau and accepted a job in Maryland. He was selected for many of the accomplishments that the Portland public had criticized him for. Ultimately, this study will show that Portland missed an opportunity to discuss how they wanted to be policed, and what philosophies they wanted their enforcers to personify. 


\section{Acknowledgements}

To Becca, Malee, Max and Bob most of all.

I would like to thank Professor Garrison for walking me through this project. He was a great editor, and a wonderful springboard for ideas. He also pushed me past my comfort zone, and encouraged me to take risks in this process and I very much appreciate it. Professor Barber has always been a great resource during my Portland State experience, and I would like to thank her for that. I appreciate the contributions of Professors Johnson and Renauer in critiquing this thesis.

Brian Johnson and Mary Hansen at the City of Portland Archive \& Records Center could not have been more helpful! Portland is very fortunate to have a city auditor's staff that is so committed to keeping our records accessible. Lisa Loving of the Portland Skanner assisted me with access to her personal archive, which was unbelievably helpful. Eliza Canty-Jones of the Oregon Historical Quarterly offered so much encouragement and Scott Daniels and Matthew Cowan at Oregon Historical Society's Research Library provided some tremendous source material.

For the history friends, I need to thank Andy, Dave, Terry, Heather, other Heather, JB and JD, Joe, Finn, John, Sarah, Marty, James, Barney, Kelly, Jimbo, Jeff, Jefferson, other Jeff, Leah, Melissa, Will, Brock and Aaron. Many of you gave me encouragement on this project, and helped me talk through these threads in my head, and then put them on to paper. Some of you are also an inspiration in your research and writing, and I really should thank you more often, as I do so appreciate it!

I think Carol, Art, Stan and Bernice would have been quite proud. Finally. 


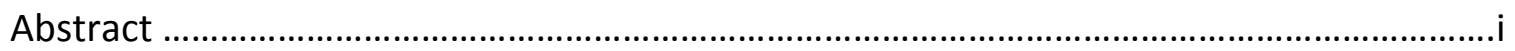

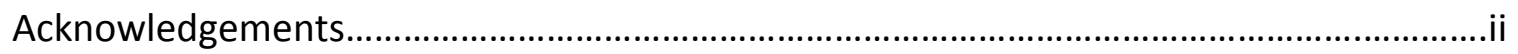

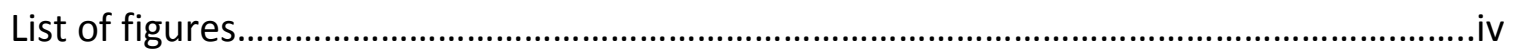

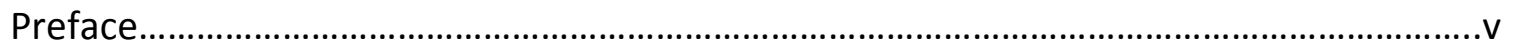

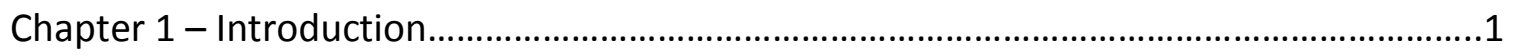

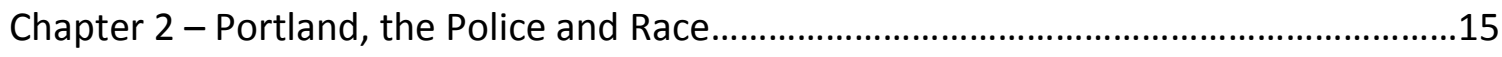

Chapter 3 - The Rise of Charles Moose within the Portland Police Bureau.......................35

Chapter 4 - Becoming Chief of Police Charles Moose.....................................................64

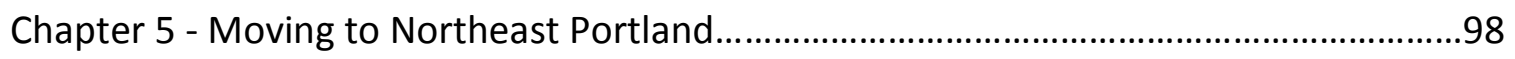

Chapter 6 - Birthday Parties and Bean Bags.................................................................136

Chapter 7 - The Binns Report, the NOBLE Conference, and Departure............................152

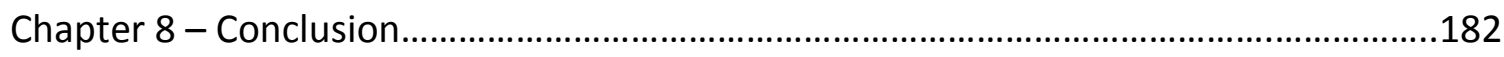

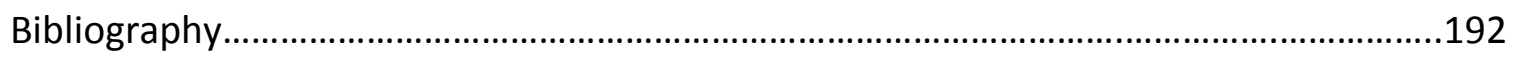




\section{List of Figures}

Fig 1 Chief Charles Moose.

Fig 2 Black Lives Matter March, Portland, November 27, 2015 .......................................................

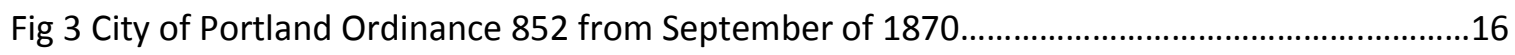

Fig 4 The Burger Barn in December, 2015 - 3962 NE Martin Luther King Jr Blvd............................27

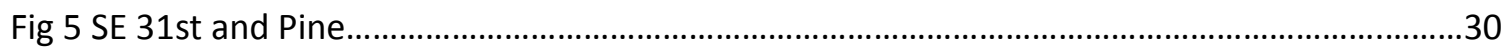

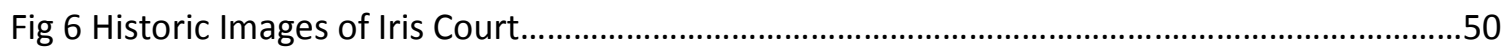

Fig 7 "Lt. Charles Moose hands out job and education information at Iris Court Open House." 52

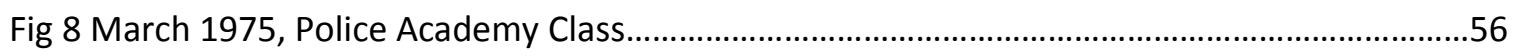

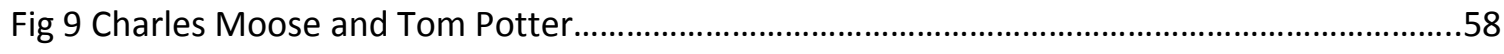

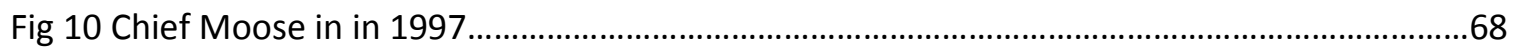

Fig 11 Mayor Katz, Chief Moose and Attorney General Reno walk through the King

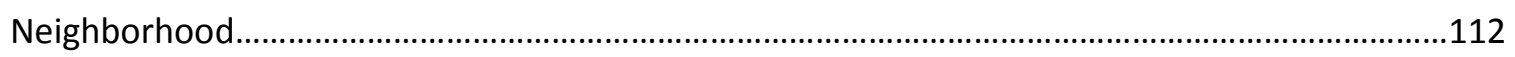

Fig 12 Charles and Sandy Moose's House Today - 422 NE Going.................................................124

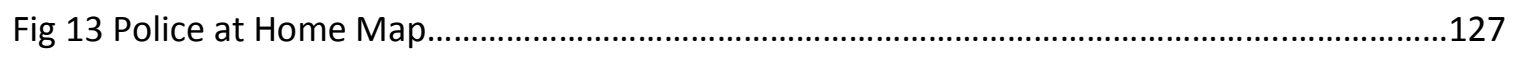

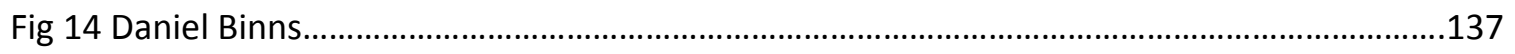

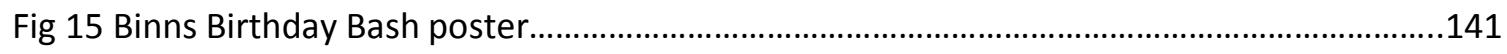

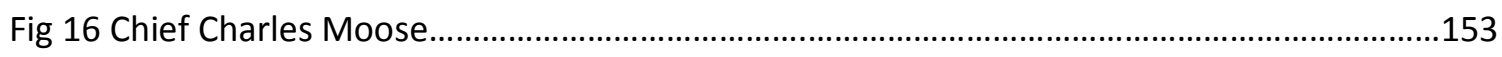

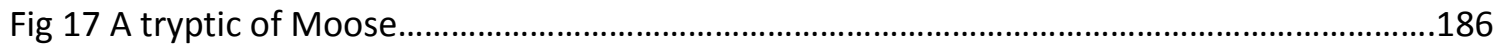




\section{Preface}

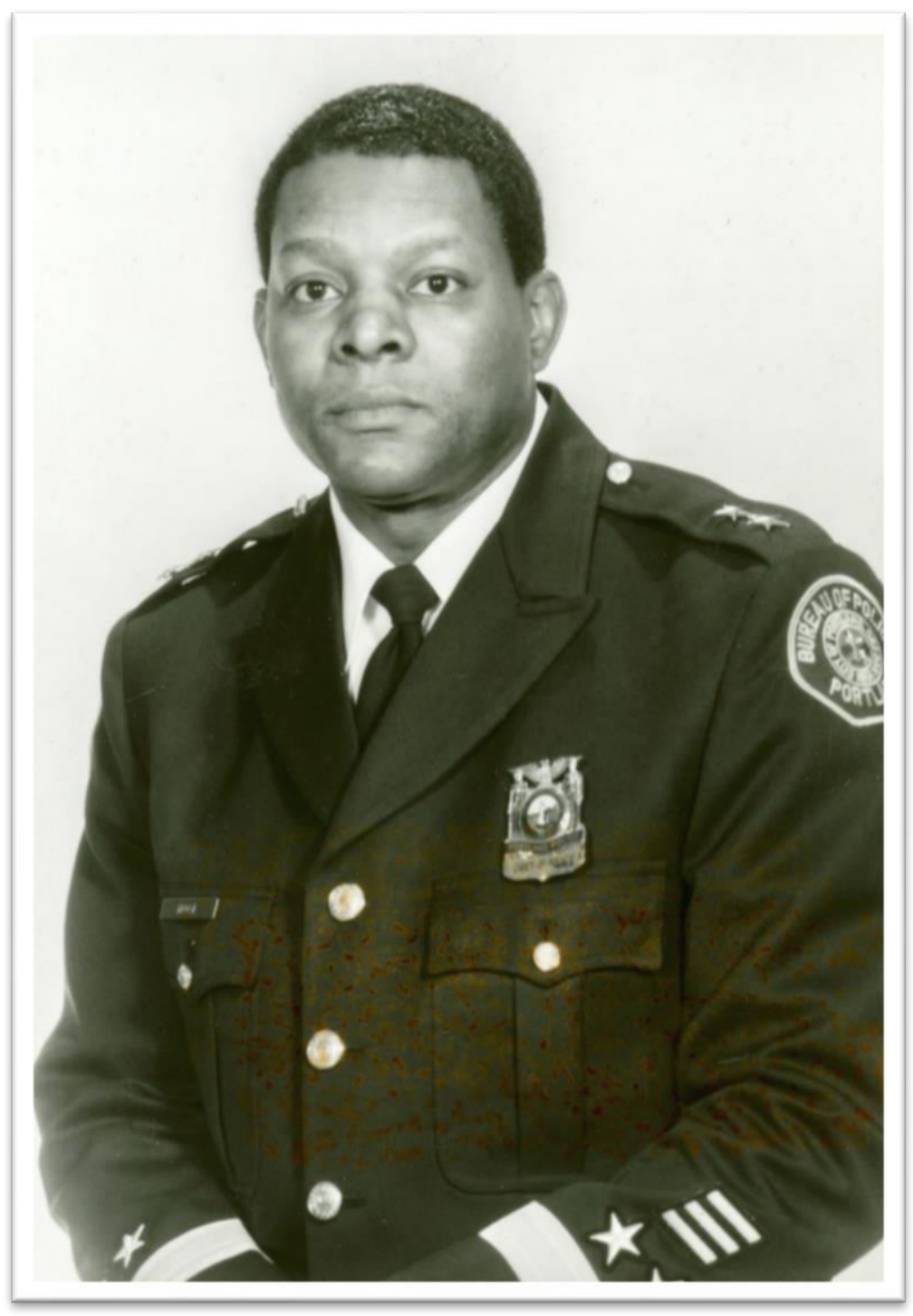

Figure 1 Chief Charles Moose. Courtesy of Oregon Historical Society, Image bb013831.

"But at any point in its history that area [Oregon] is not known to be highly populated with people of color."1

-Charles Moose, September 9, 2012

\footnotetext{
${ }^{1}$ Brien R. Williams, Interviewer. "Oral History Interview, Charles A. Moose, 9/9/2012." National Law Enforcement Museum.
} 


\section{Chapter 1 - Introduction}

Marches, protests and die-ins across the nation demonstrate that our fellow Americans have seen enough white police officers killing young black men and women. While writing this paper, "Black Lives Matter" is a rallying cry and Ferguson, Dallas, Michael Brown, Freddie Gray, Philando Castile, Alton Sterling, and Treyvon Martin are names heard in daily conversation - not just people and places relegated to history

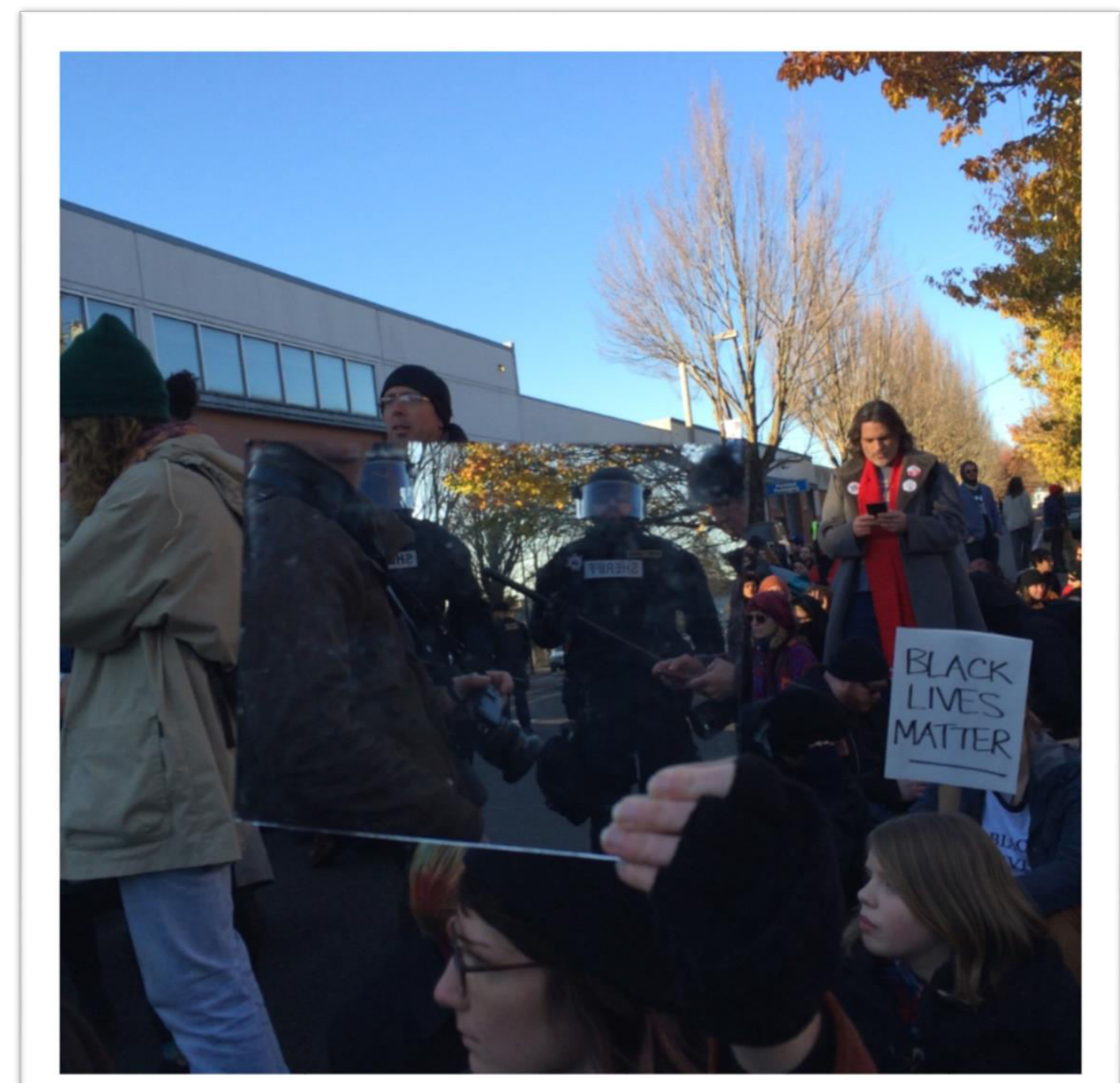

Figure 2 Black Lives Matter March, Portland, November 27, 2015. Photo by author. 
books. Communities across this country are loudly discussing "the validity of black lives" and how their largely white police organizations, many times staffed with white leaders, police the people of color they serve. ${ }^{2}$ Portland, Oregon is finding this discussion carried out on her fair streets as well. In July of 2016, just about a week after his swearing in as the Chief of the Portland Police Bureau, Mike Marshman said, "This is a time where the members of the community, as well as the members of the Portland Police, have lost faith in its leaders." 3

Portland is, and always has been, a very white city. But Portland had a very unique opportunity to address how its black communities were policed in the 1980s and 1990s. Charles Moose was Portland's first black chief of police, and through his innovative techniques of community policing, developed over decades on the streets and in the classrooms of this city, he attempted to have the Portland Police Bureau (PPB) become a leading organization in transforming the lives of Portland's black residents. This thesis will demonstrate that Charles Moose championed the theory and strategies of community policing, but Portlanders were never able to look past his demeanor and his race, and thus lost an opportunity to make community policing an integral component of local law and order.

\footnotetext{
2 “About the Black Lives Matter network," Black Lives Matter website, accessed 3/31/2016 http://blacklivesmatter.com/about/

3 "Statement from Chief Mike Marshman Regarding 2006 Investigation," Portland police Bureau statement, 7/5/2016, accessed http://www.portlandoregon.gov/police/news/read.cfm?id=7396\&ec=1\&ch=twitter
} 
Many books and academic journals have covered the subject of policing, and police chiefs specifically, over the decades. In addition, policing in the Pacific Northwest, and Portland in particular, has drawn the attention of historians, authors, and publishers. This next section will point out highlights of that argosy, and hopefully be a resource for researchers interested in this specific topic.

In 1941, the Journal of Criminal Law and Criminology covered an interesting development in Flint, Michigan, which was conducting a nation-wide, competitive search for a new police chief. The journal editorialized that "this is an encouraging sign. The chief obstacle to the establishment of police schools has been the fact that residence and civil service requirements are such that there is little to offer a person who desires to qualify as a police administrator. An engineer can go anywhere in search of jobs - the policeman cannot. The only road to advancement is the slow one of rising step by step in the home department." 4 It was also stated that in addition to Flint, this process was being adopted by "the men" in Berkeley, California and Wichita, Kansas; Pasadena, California; and Two Rivers, Wisconsin. Another noteworthy article from the Journal of Criminal Law and Criminology in 1946, drew the reader's attention to the job posting, and national search, for the police chief of Seattle, Washington. The selection, the authors said, may well "mark the beginning of a new era in metropolitan police organization and administration." Involving a multi-tiered competitive examination process, the authors noted that, "leaders in the American police field are following this

\footnotetext{
4 "Searching for Police Chiefs," Journal of Criminal Law and Criminology 32 (1941): 341-342.
} 
procedure with interest and express the hope that the ultimate results will stimulate other cities to consider the merits of this method of selecting the chief executive." 5

Several studies have examined the diversification of police leadership. Off Our Backs, published in June of 1990, detailed the rise of Elizabeth Watson to the role of Houston's police chief, "the first woman to be the police chief in one of the 10 largest cities in the U. S." ${ }^{6}$ Dr. Susan Marin, author of a Police Foundation study on women in the police forces, said "police work is typically one of the most male-dominated occupations. For a woman to achieve the position of chief in one of the largest departments in the country is a major event."7 William G. Lewis examined the represented number of blacks in police organizations, including police chiefs, in his 1989 Public Administration Review article entitled "Toward Representative Bureaucracy: Blacks in City Police Organizations, 1975-1985." 8 In his assessment, Lewis found that the number of blacks within sworn ranks in police departments increased by four percent, patrol ranks by five percent, and command ranks by three and a half percent during the ten year period of the study. ${ }^{9}$

Police chiefs writing about their experiences, and others chronicling those careers, have a deep tradition in American history. Published in the nineteenth century, George Walling's Recollections of a New York Chief of Police, may be one of the seminal tomes

\footnotetext{
5 “Current Notes," Journal of Criminal Law and Criminology 37 (1946): 66-67.

6 J.R. (sic), “Another First Woman - Houston Police Chief," Off Our Backs 20 (1990): 5.

7 J.R. "Another First Woman - Houston Police Chief," 5.

${ }^{8}$ William G. Lewis, "Toward Representative Bureaucracy: Blacks in City Police Organizations, 1975-1985."

Public Administration Review 49 (1989): 257-268.

${ }^{9}$ Lewis, "Toward Representative Bureaucracy," 261.
} 
on the topic. In it, the author chronicles his thirty years in law enforcement. ${ }^{10}$ Herbert Jenkins examined the role of a police chief in Georgia during the Civil Rights movement in his book Keeping the Peace: a Police Chief Looks at His Job. Dorothy Moses Schultz consulted the paths that women have taken to become the lead administrators in their departments in her book, Breaking the Brass Ceiling: Women Police Chiefs and their Paths to the Top. ${ }^{11}$

The selection process of the chief of police has yielded significant several reports as well. In 1999, the International City/ County Management Association published Selecting a Police Chief, which is a guidebook to assist organizations with the process, as well as a tool for prospective candidates to understand what political institutions are seeking. ${ }^{12}$ Daniel S. McDevitt and Mark W. Field used their combined seventy years of law enforcement experience as a basis for their book, Police Chief: How to Attain and Succeed in This Critical Position, which not only addresses the selection process, but provides the successful candidate with "points to remember" in creating a fruitful career. $^{13}$

Bringing the discussion to a more local scope, there are several broad-based histories of the Pacific Northwest that expend some ink in addressing the social climate that

\footnotetext{
${ }^{10}$ George W, Walling, Recollections of a New York Chief of Police (New York, Caxton Book Concern, 1887). ${ }^{11}$ Dorothy Moses Schultz, Breaking the Brass Ceiling: Women Police Chiefs and their Paths to the Top (Westport, CT.: Praeger Publishers, 2004).

12 Michael J. Kelly in 1975 published Police Chief Selection; a Handbook for Local Government, which offered similar guidance for municipalities.

${ }^{13}$ Daniel S. McDevitt and Mark W. Field, Police Chief: How to Attain and Succeed in This Critical Position (Springfield IL: Charles C. Thomas, Publisher, 2010).
} 
necessitated policing in the region. In Kimbark McCall's three volume history of Portland, Merchants, Money and Power: The Shaping of a City, and The Growth of a City, the author maintains that Portland was a "society devoted to enterprise," and that the town rose like many of its nineteenth-century contemporaries where "merchantturned-entrepreneur dominated towns and regions beyond."14 Jewel Lansing's Portland: People, Politics and Power, 1851 - 2001, and Lansing \& Freed Leeson's Multnomah: The Tumultuous Story of Oregon's Most Populous County, provide the context for policing in Portland..$^{15}$ Lansing's Portland is effective in pointing out how corrupt, and indeed publicly corrupt, the civil servants of this city were, all the way up to World War Two. Michael Munk's The Portland Red Guide: Sites \& Stories of Our Radical Past examines the history of "progressive Portland." He asserts that Portland has always had a radical element in the population that stays fairly underground, but becomes quite public and vocal in response to actions by the power elite, and often the Portland police. ${ }^{16}$ Looking from a larger perspective, but still with a regional focus, Carlos Schwantes's The Pacific Northwest: An Interpretive History is a solid broad-based narrative. ${ }^{17}$ Schwantes assembles a history of a colonial hinterland harvested for resources until it gains more

\footnotetext{
${ }^{14}$ Kimbark MacColl, Merchants, Money \& Power; The Portland Establishment, (the Georgian Press, 1988), XV.

15 Jewel Lansing, Portland: People, Politics and Power, 1851 - 2001, (Corvallis: Oregon State university Press, 2005) and Jewel Lansing \& Freed Leeson, Multnomah: The Tumultuous Story of Oregon's Most Populous County, (Corvallis: OSU Press, 2012).

${ }^{16}$ Michael Munk, The Portland Red Guide: Sites \& Stories of Our Radical Past, (Portland: Ooligan Press, 2007).

${ }^{17}$ Carlos Schwantes, The Pacific Northwest: An Interpretive History, (Lincoln: University of Nebraska Press, 1996).
} 
economic significance with WWII, and Morrissey illustrates her theory that the Inland Empire is not a geographic region, but rather a mental construction of perceptions of the region.

Portland's municipal neighbor to the north, Seattle, Washington, has always had a dependent and intertwined relationship with the City of Roses in the expansion and development of the Pacific Northwest. A number of academic articles have explored policing in that municipality as well. Selections such as Dennis E. Hoffman and Vincent J. Webb's Oregon Historical Quarterly article, “Police Response to Labor Radicalism in Portland and Seattle, 1913-19," Charles P. LeWarne's Arizona and the West, "The Bolsheviks Land in Seattle: The "Shilka" Incident of 1917," and "The Seattle General Strike of 1919,"by Robert L. Friedheim in the The Pacific Northwest Quarterly, all examine radical labor movements of this extraction-based city and the efforts of the power structure to police these reactions. ${ }^{18}$ More of these themes can be found in Terry Willis's “The Black Hole of Seattle: The Socialist Free Speech Movement, 1906-1907," in the The Pacific Northwest Quarterly, Jonathan Dembo's “John Danz and the Seattle Amusement Trades Strike, 1921-1935,"in The Pacific Northwest Quarterly, and "Civic Groups, Political Action, and City Planning in Seattle, 1892-1915," by Mansel G.

\footnotetext{
18 Dennis E. Hoffman and Vincent J. Webb, “Police Response to Labor Radicalism in Portland and Seattle, 1913-19," Oregon Historical Quarterly 87 (1986): 341-366, Charles P. LeWarne, "The Bolsheviks Land in Seattle: The "Shilka" Incident of 1917," Arizona and the West 20 (1978): 107-122, and Robert L. Friedheim, "The Seattle General Strike of 1919," The Pacific Northwest Quarterly 52 (1961): 81-98.
} 
Blackford can be found in the 1980 Pacific Historical Review. ${ }^{19}$ As the reader can see from these titles, the "radical" or political actions of left-leaning groups in Seattle, and the attempts of the ruling elite to police these labor movements, is a bountiful topic.

Some academic journals have looked at policing within Portland specifically. Charles Abbot Tracy III laid out a three part series in the Oregon Historical Quarterly in 1979 that researched "Police Function in Portland, 1851-1874." In this foundational study, Tracy demonstrated that Portland followed along with the rest of the nation in establishing a force that was entrenched in partisan political control, designed to "protect those social activities that were thought to be essential to the survival of the community." 20 "Black and Blue: Police-Community Relations in Portland's Albina District, 1964-1985," by Leanne C. Serbulo and Karen J. Gibson, appeared in the Oregon Historical Quarterly in 2013. This study deals with several of the incidents cited in the selection you are reading right now, and is a great resource for readers interested in the policing of Northeast Portland. "Vanport Conspiracy Rumors and Social Relations in Portland, 1940-1950," by Stuart McElderry, also appeared in the Oregon Historical Quarterly in 1998. This piece does not necessarily serve to prove or disprove the whispers that authorities hid 600 bodies resulting from the disaster. Instead, McEldery uses the conspiracy rumors to

\footnotetext{
${ }^{19}$ Terry R. Willis, "The Black Hole of Seattle: The Socialist Free Speech Movement, 1906-1907," The Pacific Northwest Quarterly 91 (2000): 124-135, Jonathan Dembo, "John Danz and the Seattle Amusement Trades Strike, 1921-1935," The Pacific Northwest Quarterly 71 (1980): 172-182, and Mansel G. Blackford, “Civic Groups, Political Action, and City Planning in Seattle, 1892-1915," Pacific Historical Review 49 (1980): 557-580.

${ }^{20}$ Charles A. Tracy III, "Police Function in Portland, 1851-1874, Part. I," Oregon Historical Quarterly 80 (1979): 6.
} 
better understand social relations in 1940's Portland - "a complex web of mistrust and antagonism between different groups of Portlanders." 21 Jules Boykoff and Martha Gies co-authored a piece titled, "'We're going to defend ourselves': The Portland Chapter of the Black Panther Party and the Local Media Response," that was published by the Oregon Historical Quarterly in 2010. ${ }^{22}$ The selection examines the history of the Black Panthers in Portland, but also the shortcomings of the two dailies in their coverage of the Party, and its intersection with the Portland police. Kenneth D. Rose's article, "The Labbe Affair and Prohibition Enforcement in Portland," found in a 1986 edition of the The Pacific Northwest Quarterly, examines a unique moment in Portland's prohibitionera policing where state officers actually raided the private home of a prominent business leader of the city..$^{23}$

Historians have produced several excellent book-length volumes examining specific incidents of policing in Portland, and these missives provide some background as to how crime management has evolved in our city. Peter Boag's Same Sex Affairs: Constructing and Controlling Homosexuality in the Pacific Northwest is likely the best of the lot. ${ }^{24}$ Boag examines how identification of "crimes against nature" developed as a threat to area families, and thus became a main thrust of law enforcement to keep society "safe"

\footnotetext{
${ }^{21}$ Stuart McElderry, "Vanport Conspiracy Rumors and Social Relations in Portland, 1940 - 1950," Oregon Historical Quarterly 99 (1998): 160.

22 Jules Boykoff and Martha Gies, "We're going to defend ourselves": The Portland Chapter of the Black Panther Party and the Local Media Response," Oregon Historical Quarterly 111 (2010):278 - 311.

${ }^{23}$ Kenneth D. Rose, "The Labbe Affair and Prohibition Enforcement in Portland," The Pacific Northwest Quarterly 77 (1986): 42-51.

${ }^{24}$ Peter Boag, Same Sex Affairs: Constructing and Controlling Homosexuality in the Pacific Northwest (Berkley: University of Cailf. Press, 2003).
} 
from homosexuals. As the title suggests, the book examines the region; but in reality, most of the study revolves around turn of the twentieth-century Portland. Gloria Myers's A Municipal Mother: Portland's Lola Greene Baldwin, America's First Policewoman examines the role that Baldwin had in enforcing morality in that city, as well as providing an early glimpse into promoting diversity among the policers of Portland. ${ }^{25}$ In her book, Myers argues that when Baldwin policed Portland's public morality, she was enforcing what the power elite in the city considered acceptable.

Representation of the era of "the sixties" is solid as well. Dory Hylton's master's thesis, The Portland State Student Strike of May 1970, is a wonderful study that examines the Park Blocks melee between the Portland Police Department and radical anti-war protestors that resulted in dozens being sent to Portland hospitals. ${ }^{26}$ Matt Love's The Far Out Story of Vortex 1 documents the state-sanctioned rock festival held at Mclver State Park, and approved by Governor Tom McCall, that was an effort to police a massive peace protest that was developing at the time. Moving up a few decades, to right before the era of this research project, Elinor Langer's A Hundred Little Hitlers: The Death of a Black Man, the Trial of a White Racist, and the Rise of the NeoNazi Movement in America profiles the murder of Mulugeta Seraw and the resulting civil trial of infamous white supremacist Tom Metzger, who was tried in Portland. ${ }^{27}$ Langer's

\footnotetext{
${ }^{25}$ Gloria Myers' A Municipal Mother; Portland's Lola Greene Baldwin, America's First Policewoman, (Corvallis: Oregon State University Press, 1995).

${ }^{26}$ Dory Hylton, "The Portland State University Strike of May 1970: Student Protest as Social Drama," (Ph.D. diss., University of Oregon, 1993).

${ }^{27}$ Elinor Langer, A Hundred Little Hitllers (New York: Metropolitan Books, 2003).
} 
study is important in that it examines how the citizens of the city refused to confront a home-grown racism - Nazi skinheads - while at the same time basking in its public acceptance of "tolerance" and supposed city-wide liberal values.

While some scholarship on the policing of the Pacific Northwest is available, few students have examined the subject of this study: Charles Moose and his tenure with the Portland Police Bureau. Charles Moose, fortunately, was a very good source on his own career. The researcher interested in delving into his career will find a well-stocked number of selections penned by Moose himself. He was a prolific writer. He wrote a Ph.D. dissertation, and his book on the DC Sniper case, Three Weeks In October: The Manhunt for the Serial Sniper, is readily accessible. ${ }^{28}$ The book deals not only with the investigation and apprehension of the Beltway snipers, John Allen Muhammed and Lee Boyd Malvo, but also addresses quite a bit of Moose's police career in Portland. Moose also crafted a column called "Chief's Corner," found in the Portland Police Bureau's internal newsletter, The Bulletin, as well. In addition, in 2012 the National Law Enforcement Museum conducted an oral history interview with Moose. ${ }^{29}$ While much of the interview focuses on the D.C. Sniper case, Moose does offer considerable thought on other topics as well.

\footnotetext{
${ }^{28}$ Charles Moose, "The Theory and Practice of Community Policing: An Evaluation of the Iris Court Demonstration Project" (PhD Diss., Portland State University, Studies, 1993), and Charles Moose and Charles Fleming, Three Weeks In October; The Manhunt For The Serial Sniper (Waterville, Maine: Thorndike Press, 2004).

${ }^{29}$ Williams, "Oral History Interview, Charles A. Moose, 9/9/2012."
} 
Sadly, no ample historical studies of the Portland Police Bureau exist. Selections from Portland writers Phil Stanford, J.D. Chandler, and J.B. Fisher do provide some "popular history" recounting events in the department's past - and much of their interpretation of these events is quite useful in those retellings. Robert C. Donnelly's Dark Rose: Organized Crime and Corruption in Portland is a more traditional academic account of the bureau, but it mainly follows the same retelling of Portland's vice-filled past, and the police's role in organizing and profiting from those interests. ${ }^{30}$ The aforementioned book, A Municipal Mother, by Gloria E. Myers, provides a well-researched study of the bureau in the nineteen-teens. Retired Portland Police Officer Don DuPay recently selfpublished a memoir of his career on the force in the 1950s and 60s entitled Behind the Badge in River City, in which he examines the difficulties of being a "clean cop" on a "dirty force." 31 In Moose's Ph.D. dissertation (discussed further in this work), the author did construct a fairly solid overview of the history of the bureau. Obviously, this would be a fruitful avenue for future researchers and a comprehensive, well-researched history of the Portland Police Bureau would benefit the citizens of the city greatly. But in order to have a balanced and authoritative volume, the bureau would need to buy into the project, and be quite forthcoming, transparent, and open with their historical records - a trait this researcher did not find with the current administration at the organization.

\footnotetext{
${ }^{30}$ Robert C. Donnelly, Dark Rose; Organized Crime \& Corruption in Portland (Seattle: UofW Press, 2011). ${ }^{31}$ Don Dupay, Behind The Badge In River City (Portland: Oregon Greystone Press, 2015).
} 
Much of this thesis focuses on the public perception of Charles Moose and the effectiveness of his policing activities in the City of Roses. The project relies heavily upon newspaper archives and letters from constituents in the city. This examination provides a real reading of the pulse of Portland and tries to get to the core of what the citizens of the 1990s felt about their police chief.

This survey will examine specific incidents in Moose's career that allow us to consider the confluence of race and policing in "America's whitest city." This paper will not examine later experiences of Moose's policing career, such as his role in stopping the October 2002 D.C. Beltway Sniper case, where 10 people died from random terrorist attacks. ${ }^{32}$ Nor will this paper present a comprehensive study of the Portland police and its relations with our racial communities over an extended period of time. While this would be a truly impressive study, and one worthy of the attention of future scholars, it is beyond the scope of this investigation.

The next chapter will examine race and policing in Oregon, provide a background of the Portland Police Bureau, and set the scene of Charles Moose's entrance into that agency. Chapter Three will examine Moose's biography, and trace his advancement within the Portland Police Bureau. Chapter Four will examine his appointment to the highest policing position in Portland. The fifth chapter will document his historic move to Northeast Portland, and the impression that left on his fellow citizens and police

32 "A Byte Out Of History, Part 1," FBI website accessed 11/11/2015 https://www.fbi.gov/news/stories/2007/october/snipers 102207 
officers. Chapter Six will detail the Daniel Binns Beach Party, and the protest march on the Moose's home. The seventh chapter will examine the resulting report that Chief Moose delivered to the City Council, and the schism that developed between him and the community he was selected to serve and protect. That chapter will additionally lay out Moose's involvement with the National Organization of Black Law Enforcement officials (NOBLE), his last act as Portland's police chief. Chapter Eight will conclude this selection, and offer some analysis (both from the period, and in hindsight) of the career and impact of Portland's first black police chief. 


\section{Chapter 2 - Portland, the Police and Race}

"Control of the police was, seemingly,

as important for $19^{\text {th }}$ century politicians as it is for their more contemporary counterparts..."

- Historian Charles Abbot Tracy $\mathrm{III}^{38}$

To begin this discussion, it might be helpful to take a higher level view of the topic and consider the concept of policing. What is the police officer's role in a defined society? What is policing? The subject of this paper, Charles Moose, offered some thoughts on the matter when he wrote in his PhD dissertation: "Policing is one of the major, formal devices designed to bring about the regulation and control of behavior in a community. If social disapproval and other informal social processes fail to contain crime, drug abuse, and sociopathic behavior, the police are then expected to provide a main line of defense against deviants and law breakers. Parenthetically, the police in modern societies are also charged with the maintenance of public order as well as with the control of crime."39

The City of Portland, Oregon, was founded in 1843, but not incorporated until February $8^{\text {th }}, 1851$. Right from the beginning, there was a provision for a City Marshal to serve as the city's "principal ministerial officer." ${ }^{40}$ Historians have generally considered

\footnotetext{
${ }^{38}$ Charles A. Tracy III, “Police Function in Portland, 1851-1874, Part. II" Oregon Historical Quarterly 80 (1979): 168.

${ }^{39}$ Charles Moose, "The Theory and Practice of Community Policing: An Evaluation of the Iris Court Demonstration Project" (PhD Diss., Portland State University, Doctor of Philosophy in Urban Studies, 1993): 1.

40 Moose, "The Theory and Practice of Community Policing," 50.
} 
law enforcement throughout the nineteenth century in the western United States to

have been inadequate, and

Portland was certainly no

exception to this broad

generalization. ${ }^{41}$ The city

marshal position became an

elected one, and partisan

politics played a significant

role in Portland's policing. ${ }^{42}$

Again, this was right in line

with national trends, as

historians have considered

partisan politics and their

influence as "one of the

recurring problems of

nineteenth century

American policing,"

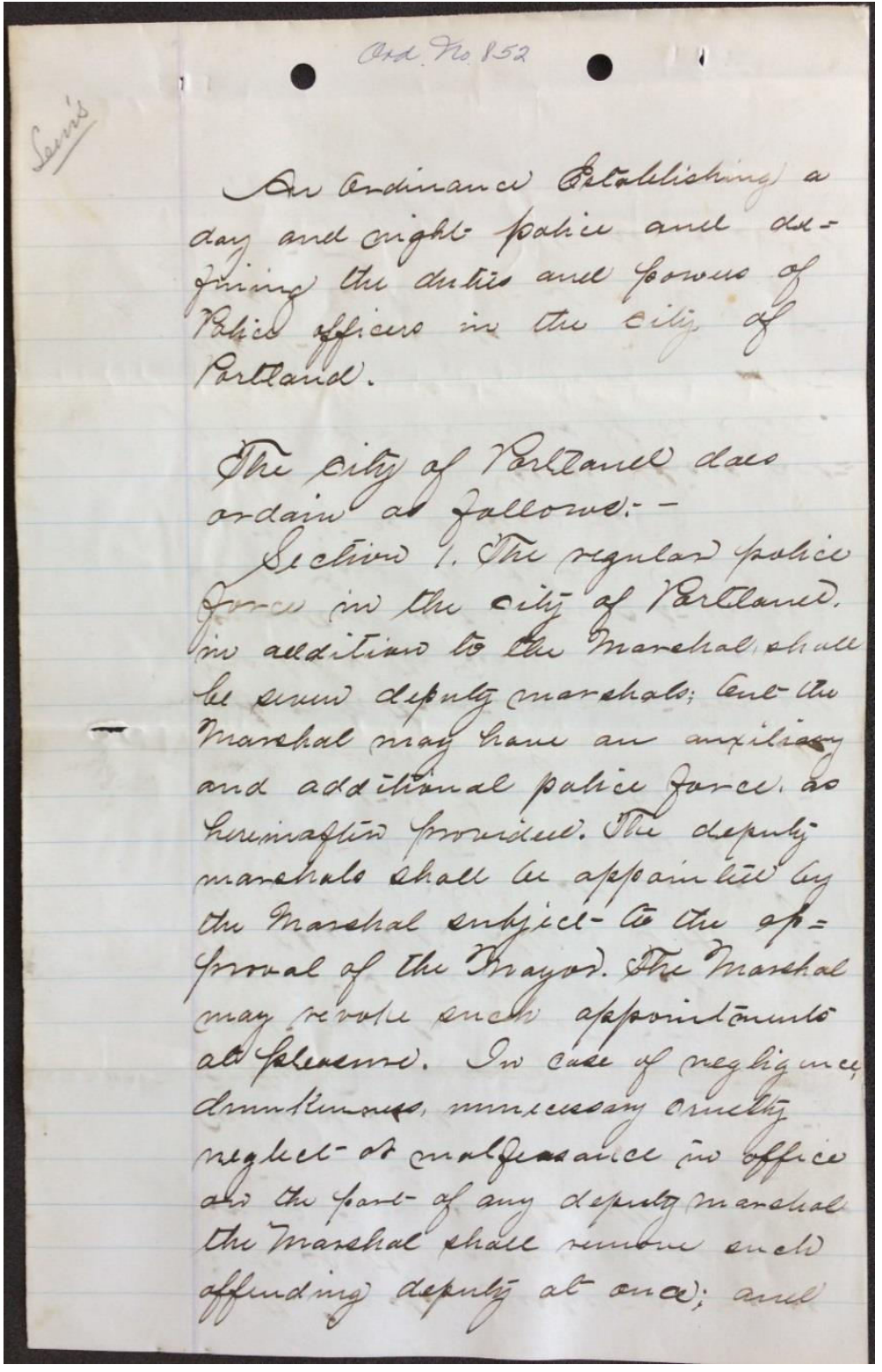

Figure 3 City of Portland Ordinance 852 from September of 1870. City of Portland Archives.

\footnotetext{
${ }^{41}$ Mitchel P. Roth, Crime and Punishment; A History of the Criminal Justice System, (Belmont, CA: Thompson Wadsworth, 2005), 149.

${ }^{42}$ Moose, "The Theory and Practice of Community Policing," 51.
} 
although the national concern was the power of "the police to control the election machinery." ${ }^{\prime 3}$

Slowly, the organization that was policing Portland grew from a one man operation into something that could resemble a "force." In July of 1858 , two deputy marshals appeared on the payroll. ${ }^{44}$ The bureaucratic body constructed to police this political space called Portland was not created until almost 20 years later, in 1870 . When the city passed Ordinance 852 in September of that year, the population of Portland was about 9,000 residents. ${ }^{45}$ According to the Portland Police Bureau (PPB) website, the council passed an ordinance establishing the Portland Police Force, which included six patrolmen, a lieutenant, and a chief named Phillip Saunders. Partisan politics was again present in the sphere of policing, and James Lappeus was appointed chief. Of Lappeus's patrolmen, who were serving on appointed positions, only two had police experience or proper qualifications. ${ }^{46}$ All the officers were "loyal Democrats." ${ }^{47}$ In many ways, the Portland Police Bureau was like other police departments across the nation.

Eleven years later, the city fixed officer selection standards. The criterion for being an officer were U.S. citizenship, having resided in Portland for one year, being able to read and write English, an absence of a criminal record, to "be of good health, sound body

\footnotetext{
${ }^{43}$ Roth, Crime and Punishment, 149.

${ }^{44}$ Tracy, "Police Function in Portland," 28.

39 Tracy, "Police Function in Portland,"166.

46 Moose, "The Theory and Practice of Community Policing," 52

47 Tracy, "Police Function in Portland," 293.
} 
and mind," and a minimum of 5'10 in height and 175 pounds in weight. ${ }^{48}$ A professional police force for Portland was well on its way to serving the city; but due to the influence of the political patronage, an environment that allowed corruption was able to fester and grow. ${ }^{49}$ As historian Charles Tracy has asserted, "by the end of the nineteenth century the Portland police were completely controlled by the prevailing politicaleconomic power."50

It was not until Chief Jenkins, the longest tenured chief of police in Portland, began his reign in November of 1919 that the bureau was able to "significantly reduce the political influence on the police." ${ }^{51}$ Chief Jenkins also improved the technological aspect of policing in the city (radio was a new introduction), and he reorganized and created innovative, new departments. Burdening the chief were accusations of corruption during the era of that failed social experiment, Prohibition. Charges against Chief Jenkins's police force were regular and quite public during his tenure. Police departments across the nation were plagued with corruption during this time, and the West Coast should not be excluded from this generalization. ${ }^{52}$

In his book, Portland Confidential: Sex, Crime and Corruption in the Rose City, Phil Stanford acknowledges as much when he wrote that decades after the formation of the

\footnotetext{
48 "History of the Portland Police Bureau," Portland Police Bureau website, accessed 1/28/2016. https://www.portlandoregon.gov/police/40004

${ }^{49}$ Paraphrasing from Moose, "The Theory and Practice of Community Policing," 53.

50 Tracy, "Police Function in Portland," 322.

51 Moose, "The Theory and Practice of Community Policing," 53.

52 Roth, Crime and Punishment, 260. Los Angeles was particularly bad, reaching "into the highest levels of the department," and "pervaded city politics unabated."
} 
Portland Police Bureau, the City of Roses was a wide-open town and known throughout the nation as "a Mecca of vice and sin." 53 Peddlers of the "traditional vices" operated unmolested by local law enforcement. "All you had to do was pay them off - them, and of course their bosses in city hall. Portland had a payoff system, going back well into the nineteenth century," Stanford maintains. ${ }^{54}$ Historian Robert Donnelly also supports these findings, and notes that "the sensational vice crimes of Portland seemed to conform to a fairly commonplace pattern of nationwide urban corruption in the postWorld War II era." 55

The post-war period was pregnant with several high profile investigations into corruption in Portland. The City Club conducted two studies, one in 1945 and the other in 1947 , that found that vice peddlers were protected by city officials "in consideration of substantial 'payoff' to some police officers and public officials." 56 Portland then attracted national attention when the 1957 Senate Select Committee on Improper Activities in the Labor or Management Field (more widely known as the "McClellan Committee") concluded that the Teamsters were linked with municipal corruption and organized crime. ${ }^{57}$ The committee examined cities as diverse as New York, Detroit, Chicago, and Portland. Implicated in the investigation was Portland's mayor (and former

\footnotetext{
53 Phil Stanford, Portland Confidential; Sex, Crime and Corruption in the Rose City, (Portland: WestWinds Press, 2004), 9.

${ }^{54}$ Stanford, Portland Confidential, 9.

55 Robert C. Donnelly, Dark Rose; Organized Crime \& Corruption in Portland, (Seattle: University of Washington Press, Seattle, 2011), 3.

${ }^{56}$ Donnelly, Dark Rose, 11.

${ }^{57}$ Donnelly, Dark Rose, 143.
} 
Multnomah County Sheriff), Terry Schrunk, and District Attorney William Langley,

demonstrating that the corruption in Portland was entrenched at the highest offices of law enforcement in the city. ${ }^{58}$

Into the 1960s, Former PPB Detective Don Dupay detailed a police force filled with old-guard officers sleeping on the night shift, eating free meals at restaurants through town, and generally abusing the power of the position. ${ }^{59}$ DuPay also writes about how Captain "Diamond Jim" Purcell, the former chief of police demoted for corruption in the late 1950's, was actively accepting bribes for providing police protection to several houses of prostitution in $1967 .^{60}$

The Portland Police Bureau was also involved in suppressing freedom of speech and action. Starting in 1965, the Police Intelligence Division began an illegal surveillance program that targeted political activists and their organizations in the city. Some of the political groups did engage in criminal activity, but others were fairly benign, such as the People's Food Store Co-Op, the Women's Rights Coalition, and the Northwest Oregon Voter Registration Project. ${ }^{61}$ The program ran into the 1980 s and collected surveillance data on about 3,000 citizens and 576 organizations. The division obtained documents

\footnotetext{
${ }^{58}$ Chief Moose addressed this legacy in his City Club of Portland address, in August of 1993. Moose said "In this climate, a lot of indicators are that the police bureau has really changed its historical role as being very corrupt. We have a horrible history of corruption, of theft, of officers being involved in drugs, in bootlegging. We don't have that at this point. There's no indicators that we have that level of corruption." It is noteworthy to this researcher that even as late as 1993, the chief of police felt that it was necessary to address age-old accusations of police corruption.

${ }^{59}$ Don Dupay, Behind The Badge In River City, (Portland: Oregon Greystone Press, 2015), 117, 118.

${ }^{60}$ Dupay, Behind The Badge In River City, 191.

${ }^{61}$ Ben Jacklet, "The Secret Watchers," Portland Tribune, 9/12/2002 (Online version. DOC 3/15/2016) http://portlandtribune.com/component/content/article?id=117580
} 
from the obvious sources: surveillance and intelligence notes and news clippings and photographs, but they also collected unexpected data such as letters, signed petitions, license plate numbers of vehicles of those attending meetings and rallies, bookstore mailing lists, and lists of campaign contributors. ${ }^{62}$

On May 11, 1970, white helmeted officers of the Tactical Operations Platoon marched into the Park Blocks at Portland State University to end a week-long occupation by students and other activists protesting the invasion of Cambodia, the imprisonment of Black Panther Bobby Seale, and the shipment of nerve gas across Oregon. ${ }^{63}$ This action was not occurring in a vacuum - all over the United States violent protests were occurring on college campuses, including Kent State, where 4 students were killed by the Ohio National Guard on May 4. By May 8, more than 250 colleges across the nation had closed, and another 400 were shuttered from strikes. ${ }^{64}$ Deployment of National Guard troops commenced to twenty-one campuses in sixteen states. ${ }^{65}$ That first week of May saw thirty ROTC buildings burned or bombed, including one at the Oregon State University in Corvallis. ${ }^{66}$ Many Portlanders objected to the overt display of crowd control by the officers, and over 5,000 protestors marched on City Hall to protest the

\footnotetext{
62 Ben Jacklet, "Watcher Files Find New Home," The Portland Tribune, 1/12/2004 (online DOC 3/15/2016) http://portlandtribune.com/component/content/article?id=107945

${ }^{63}$ Gordon B. Dodds, The College That Would Not Die; The First Fifty Years of Portland State University, 1946 - 1996 (Portland: OHS Press, 2000), 302.

${ }^{64}$ Dory Hylton, "The Portland State University Strike of May 1970: Student Protest as Social Drama,"

(Ph.D. diss., University of Oregon, 1993), 36.

65 Todd Gitlin, The Sixties, Years of Hope, Days of Rage (New York: Bantam Books, 1987), 410.

${ }^{66}$ Gitlin, The Sixties, 410 - Even the ROTC building in Corvallis was firebombed.
} 
violence of the Portland Police. ${ }^{67}$ This was the environment of the Bureau that Charles Moose stepped into in 1975.

Besides graft and corruption, illegal surveillance techniques, and heavy handed responses to Portland protestors, there was an even uglier characteristic that encumbered the Portland Police Bureau. Beneath all of this policing was a city very much at odds with the black community, and a police force that was seemingly quite racist - and indeed more than willing to demonstrate that racism overtly.

According to statistics from a 2007 American Community Survey of the forty largest U.S. metropolitan areas, Portland was the fourth whitest city in the nation. And, of the cities ranked "whiter" than Portland, Minneapolis-St. Paul and Providence (tied for third place), Cincinnati, and Pittsburgh, none were west of the Mississippi, making Portland, Oregon, at the time of the study at least, the whitest city in the West. ${ }^{68}$ This is a demographic construct that continues to this day. A 2010 census report detailed that from 2000 to 2010, the inner Portland neighborhoods saw 10,000 black residents move out. ${ }^{69}$ As recently as November of 2015 , the title of an Oregonian news article on race in

\footnotetext{
67 Michael Munk, The Portland Red Guide; Sites \& Stories of Our Radical Past, (Portland: Ooligan Press, 2007)193.

${ }^{68}$ Betsy Hammond, "In a changing world, Portland remains overwhelmingly white," The Oregonian, 1/17/2009. Accessed : http://www.oregonlive.com/news/index.ssf/2009/01/in_a changing world_portland_r.html (DOC 10/13/2015)

69 Nikole Hannah-Jones, "In Portland's heart, 2010 Census shows diversity dwindling," The Oregonian, 4/30/2011. Accessed online, 3/31/2016. http://www.oregonlive.com/pacific-northwestnews/index.ssf/2011/04/in portlands heart diversity dwindles.html The author states that "most settled on the city's eastern edges." In a May, 2016 radio broadcast on Oregon Public Broadcasting's program "Think Out Loud," Lisa Bates, a professor of Urban Studies at Portland State University called into question the validity of statistics like these. Bates says that the Portland black population is so small -
} 
Portland identified this municipality as "America's whitest city." ${ }^{70}$ This label is not just a local phenomenon: the national press recognizes this racial disparity in Portland. For example, The Washington Post in March of 2015 supported this assertion, noting that with a white population of $76 \%$, Portland was indeed "the whitest big city in the U.S." ${ }^{71}$

Portland has a racist history, and the genesis of that characteristic came from the settling of this region. As historian Greg Nokes has documented, the state of Oregon was born with a government that adopted exclusionary laws. Legislation in 1843 and 1844 outlawed slavery and blacks in general, but the second exclusionary law of 1849 was more explicit. In this regulation, the Territorial Legislature decided that "it shall not be lawful for any negro or mulatto to enter into, or reside" in Oregon. ${ }^{72}$ Historian Gordon Dodds noted that the residence law was never officially used in practice. As an example, consider an 1860 census of Portland that totaled 2,917 residents, partly composed of "1,678 white males, 1,196 white females, 10 black males, 6 black females." 73 While the numbers of blacks in Oregon has always been a tiny portion of the

$3.1 \%$ - that a margin of error in the data would be quite large, and thus there could actually be no change at all. None-the-less, either viewpoint reinforces the fact of a very small population of black citizens living within Portland's urban areas. See Sage Van Wing and Scott Greenstone, "Are African-Americans Really Leaving Portland?" OPB's Think Out Loud, 5/17/2016. Accessed online, 5/20/2016 http://www.opb.org/radio/programs/thinkoutloud/segment/oregon-portland-african-americans/ ${ }^{70}$ Casey Parks, "Welcome to My World: In America's whitest city, young blogger tries to prove the black middle class exists," The Oregonian, 11/9/2015. Accessed online, 3/31/2016. http://www.oregonlive.com/living/index.ssf/2015/11/welcome to my world blogger.html ${ }^{71}$ Emily Badger, "How the whitest city in America appears through the eyes of its black residents," The Washington Post, 3/24/2015. Accessed online, 2/9/2016 https://www.washingtonpost.com/news/wonk/wp/2015/03/24/how-the-whitest-city-in-americaappears-through-the-eyes-of-its-black-residents/

72 Greg Noakes, "Black Exclusion Laws in Oregon," Oregon Encyclopedia website. Accessed 12/18/2015. http://oregonencyclopedia.org/articles/exclusion laws/\#.VnROM krK70

${ }^{73}$ As cited in Tracy, "Police Function in Portland," 136. 
population, and though they were not, in actuality, excluded, it would be a grave error to overlook the significance of these laws on Oregon's history. ${ }^{74}$ Dodds points out that it was not until after the federal constitutional amendments at the conclusion of the Civil War that these statutes were overturned. ${ }^{75}$ The seed had been sown, and a racist community was born and fostered over the ensuing decades. Dodds, in his history of the state, portrayed an Oregon encumbered with "a pervasive racism." 76 He considered Oregon's oldest social phenomenon to be "the white man's belief in his racial superiority."77

Many blacks regarded Oregon as a place where they were not welcome to settle. Up to 25,000 African Americans came to Oregon for work during World War Two, but they faced this institutionalized racism. As an example, the infamous "We Cater To White Trade Only" sign hung in the window of a North Portland café in the 1940 s. $^{78}$ Waddle's Restaurant, right off of today's Interstate 5 to Jantzen Beach (at the current site of the Hooter's restaurant) advertised white trade only as well. Red lining, which is the act of providing different services to a specific ethnic group based on race, gender, or

\footnotetext{
${ }^{74}$ Gordon Dodds, Oregon; A Bicentennial History (New York: W.W. Norton \& Co., 1977), 69. Some Chinese were occasionally arrested on discriminatory laws, however. See Charles A. Tracy III, "Police Function in Portland, 1851-1874, Part. III" Oregon Historical Quarterly 80 (1979): 306, 311.

75 Dodds, Oregon; A Bicentennial History, 69.

76 Dodds, Oregon; A Bicentennial History, 4.

77 Dodds, Oregon; A Bicentennial History, 41.

78"Luncheonette Sign, We Cater To White Trade Only," Oregon History Project website. Date accessed, 3/31/2016. http://oregonhistoryproject.org/articles/historical-records/luncheonette-sign-we-cater-towhite-trade-only/\#.Vv2YUOIrK70
} 
background, was in full force in Portland in the twentieth century. ${ }^{79}$ Through this process, blacks were kept in specific neighborhoods in Portland (typically North and Northeast Portland), leading to the development of ghettos. With black populations contained and controlled, other neighborhoods were allowed to thrive, helping create what is today a city with some of the whitest neighborhoods in the West.

These facts from Oregon's history should not be revelations or anything other than "old news" to the reader. They have been covered by reporters, filmmakers, columnists, and yes, historians, over the past few decades. Even as recently as January of 2015 , the website Gizmodo.com posted an article by Matt Novak called “White Utopia, Oregon's Racist History," which featured a sub-title of "Oregon Was Founded as a Racist Utopia." ${ }^{\prime 80}$ The article dug fairly deeply into these issues, and was widely shared on social media sites for days after the posting. Unfortunately, regardless of all the coverage, many Oregonians are not familiar with the institutionalized white-privilege and white-supremacy that this state was constructed upon, and that peoples of color have had to operate within. Consequently, many in the state see Oregon as a progressive island in a racist nation.

Portland's re-whitening has been an evolving condition. While never known as an enclave for a thriving black community, none-the-less, North and Northeast Portland

\footnotetext{
79 Bill Davidow, "Redlining for the $21^{\text {st }}$ Century," The Atlantic, 3/5/2014. Accessed online, 12/18/2015. http://www.theatlantic.com/business/archive/2014/03/redlining-for-the-21st-century/284235/

80 Matt Novak, “Oregon was Founded as a Racist Utopia." Gizmodo website. Accessed 11/15/2015. http://gizmodo.com/oregon-was-founded-as-a-racist-utopia-1539567040
} 
were more diverse neighborhoods in the 1990s. According to census data, in $1990,64 \%$

of the King neighborhood was black. ${ }^{81}$ In 2000, the Black population of King

Neighborhood had shrunk to $45.8 \%$, and by 2010 again to $25.9 \% .^{82}$

This was the Oregon that Chief Moose moved into in 1975, and three specific racial incidents defined the racist climate in 1980's Portland.

\section{The Opossum Episode}

On March 12, 1981, four dead opossums were deposited on the sidewalk in front of the Burger Barn restaurant, 3962 NE Union Ave (today, known as Martin Luther King Jr. Avenue).$^{83}$ The Burger Barn was a black-owned restaurant, and the proprietor of the restaurant claimed that witnesses saw up to seven uniformed police officers laughing and joking around before pulling the dead possums from their patrol car trunks and placing them on the sidewalk. ${ }^{84}$

Some black residents saw the incident as "a symbol of... ongoing racial harassment by police of blacks in the Albina community." ${ }^{85}$ George Powe, who owned the Burger Barn, felt that "the officers had intentionally placed the animals on the sidewalk as part of a

\footnotetext{
${ }^{81}$ City of Portland, Office of Neighborhood Associations, Neighborhood Social Profiles (1990 Census), King Neighborhood. City of Portland website. Accessed 10/13/2015. https://www.portlandoregon.gov/oni/article/58046 (DOC 10/13/2015) 1980 found very similar numbers: https://www.portlandoregon.gov/oni/article/328525

822000 and 2010 Census Profile pdf, City of Portland website, accessed 10/13/2015. https://www.portlandoregon.gov/oni/article/375918

83 Benny Evangelista, Jr., "Police tale questioned by owner," The Oregonian, 3/16/1981, B 1.

${ }^{84}$ Evangelista, "Police tale questioned by owner," B 1.

85 "Firings bring protest," The Oregonian, 3/31/1981, B 1.
} 
continuing campaign to drive customers away from the restaurant." ${ }^{86}$ This episode displayed the serious racial gap that existed between the Portland Police Bureau and

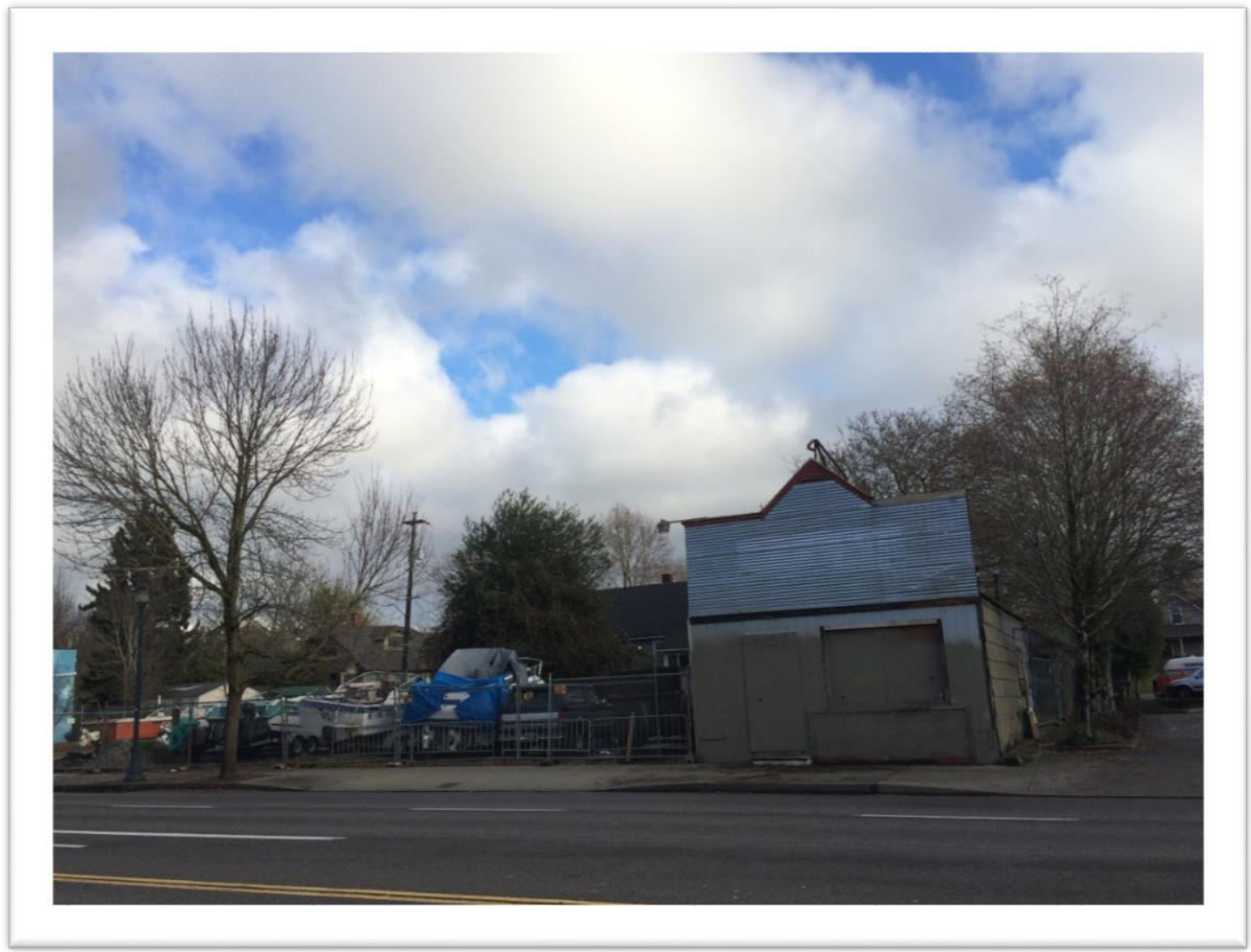

Figure 4 The Burger Barn in December, 2015 - 3962 NE Martin Luther King Jr Blvd. Photo by the author

Portland's black community at the start of the 1980s. Some officers maintained open hostility or targeted attacks against black residents. Two officers, Craig Ward and Jim Gallaway, eventually admitted to the incident. Lt. Dan Noelle, Portland police public information officer, said that the officers "claimed no intent of harassment to the

${ }^{86}$ Evangelista, "Police tale questioned by owner," B 1. 
owners of the Burger Barn, and no intent to cause racial harassment." 87 City

Commissioner Charles Jordan, who oversaw the bureau and Police Chief Bruce Baker, fired Ward and Gallaway. ${ }^{88}$

Mayor Frank Ivancie reported that the vast majority of calls to his office from fellow citizens felt that the firings were too harsh of a disciplinary action. ${ }^{89} \mathrm{~A}$ few days after the firing, an 850 person parade in support of the officers marched from the Battleship Oregon Memorial Marine Monument to City Hall. ${ }^{90}$ The organizers presented petitions, signed by nearly 10,000 Portlanders, "condemning the dismissals and demanding reinstatement of the officers. ${ }^{91}$ White Portland felt that the punishment was too much, and Mayor Ivancie agreed. The mayor said, "I think discipline was in order. I have no fault with discipline. The severity is a matter of opinion." 92

\section{2. "Tony" Stevenson Killing}

On April 20, 1985, a thirty-one year old security guard visited a convenience store in Northeast Portland. His name was Lloyd "Tony" Stevenson, and he was black. The record contains confusing and contradictory details about the incident, but a disturbance took place outside of the store, the police were called, and minutes later Stevenson lay dead in the parking lot. Officer Gary Barbour had applied a "choke hold"

\footnotetext{
${ }^{87}$ Benny Evangelista, Jr., "Police admit opossum incident," The Oregonian, 3/15/1981, B 7.

${ }^{88}$ Steve Jenning, "2 ex-officers charge politics in firings," The Oregonian, 4/4/1981, A 13. Commissioner Jordan was Portland's first African-American city commissioner.

89 "Firings bring protest," B 1.

90 Steve Jenning, "2 ex-officers charge politics in firings," The Oregonian, 4/4/1981, A 13.

91 Jenning, "2 ex-officers charge politics in firings," A 13.

92 "Firings bring protest," B 1.
} 
or "sleeper hold" to Stevenson's neck in an attempt to subdue him. ${ }^{93}$ Instead, this act killed him.

On the day of Stevenson's burial, two Portland police officers, Richard Montee and Paul Wickersham, were selling t-shirts emblazoned with the slogan “Don't Choke 'Em, Smoke "Em" to other PPB officers. The officers had 100 of the t-shirts printed up, and were selling them for $\$ 6.50$ each. Locations where the shirts had been sold were listed as numerous by varied reports and included the report room at the East Precinct, the coffee room of the training division at the downtown Justice Center, the parking lot of the East Precinct Headquarters, and the Portland Police Athletic Association Club. ${ }^{94}$ About 15 officers purchased two dozen of the shirts.

Needless to say, the black community, already angered after Stevenson's death, were further enraged by the t-shirt sales. Vesla Loving, a Boise neighborhood resident echoed these comments when she called the t-shirt incident "the most insensitive thing, like putting gasoline on a fire that is already out of control." ${ }^{\prime 95}$ Ron Herndon, co-chairman of the Black United Front, asserted that there was an element in the Portland Police Bureau that was "unfit for the serious responsibilities that the public has entrusted to them." He later said that "this is what you would expect from police hit squads in El

93 "The Suspects Who Died," The Oregonian, 5/9/1985, D 2.

${ }^{94}$ Ken Hamburg, "Fired policemen's appeal could take several months," The Oregonian, 5/9/1985, D 2, and Author unknown, "T-shirt sale backfires on policeman," The Oregonian, 4/27/1985, C 1.

${ }_{95}$ Paul Manley, "Police chief will send T-shirt disciplinary suggestion to Clark," The Oregonian, 5/7/1985, B 1. The Boise neighborhood is in North and Northeast Portland. 
Salvador."96 Mayor Bud Clark ordered the officers fired, calling his decision "a relatively easy one." 97

\section{The Murder of Mulugeta Seraw}

Saturday, November 12, 1988 is a dark day in Portland's past. On that evening, Ethiopian immigrant and Portland State University student named Mulugeta Seraw was beaten to death by three white men associated with the Nazi skinhead group, "East Side White Pride." While Seraw was leaving the Parklane apartments on 212 SE $31^{\text {st }}$, two

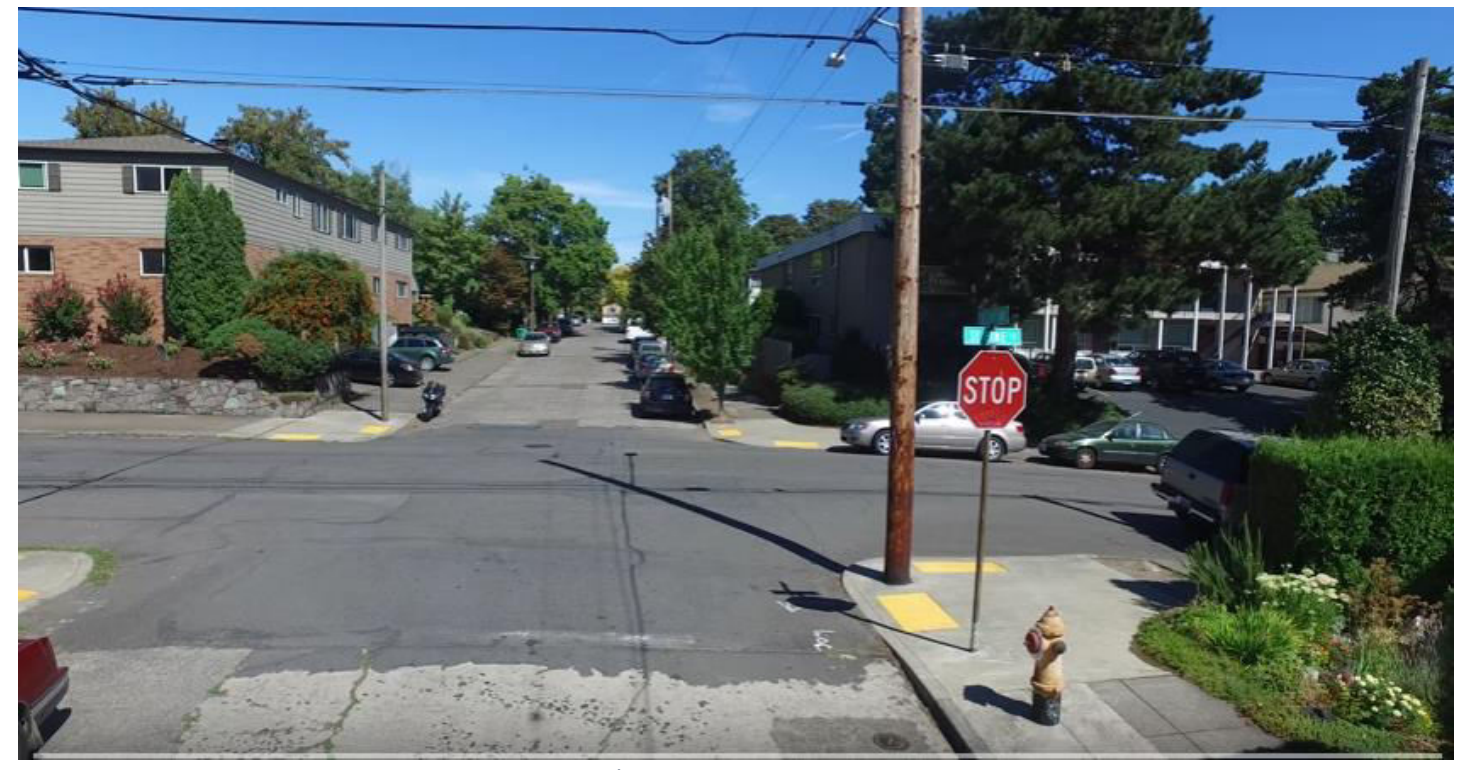

Figure 5 SE $31^{\text {st }}$ and Pine. Photo by Naim Hasan.

friends of his were engaged in a physical altercation on the street with Kyle Brewster,

Steve Strasser, and Ken Mieske (also known as "Ken Death"). ${ }^{98}$ Seraw tangled with the

\footnotetext{
96 Hamburg, “Fired policemen's appeal," D 2.

${ }^{97}$ Holly Danks and Paul Manley, "Harsh discipline asked in T-shirt incident; $2^{\text {nd }}$ officer cited," The Oregonian, 4/30/1985, B 1.

${ }^{98}$ Elinor Langer, A Hundred Little Hitlers (New York: Metropolitan Books, 2003), 35.
} 
skinheads, their boots, and their baseball bat, and he ended up in a large pool of his own blood, dying in the street.

While the death of Seraw was not at the hands of the Portland police, the murder certainly suggested that there were real racial problems in the city, and the seemingly inability of the local law enforcement authorities to police this segment of the population. Police seemed disconnected and at a loss to explain the killing. Speaking about the skinheads, one unidentified police officer said, "They're not well organized... their numbers are small, but based on activities over the past couple of months, it's obvious they are capable of loud action." ${ }^{99}$ Minority groups in Portland feared for their personal safety and demonstrated that they were frightened that the Portland police were not doing enough to keep their communities safe. ${ }^{100} \mathrm{~A}$ group of religious and community leaders called for an "aggressive response" to Seraw's murder. The coalition recommended a group of "federal, state and local law enforcement agencies be formed to gather intelligence and monitor white supremacist groups," further demonstrating the inability of the Portland police to deal with the actively racist portion of the city's population. Cathy Siemens of Oregonians for Fairness said "together, before more lives are lost, we must move past prejudice, past tolerance, past even understanding, until we can truly celebrate our diversity as Oregonians and as human beings." 101

\footnotetext{
99 Tom Hallman Jr., "White-Supremacist Skinheads Termed Fastest Growing Hate Group In Nation," The Oregonian, 11/16/1988, B 03.

${ }^{100}$ Editorial, "Calm In The Face Of Outrage," The Oregonian, 11/25/1988, C 06.

101 Tom Hallman Jr., "Racial Murder Angers Portlanders," The Oregonian, 11/17/1988, B 02.
} 
In the four weeks after Seraw's murder, racist violence surged in the city. The police suspected that Skinhead groups were involved in thirteen assaults and robberies, and two new factions were recruiting new members. The Portland police public information officer seemed to sum up the bafflement of the bureau when he said "we're constantly amazed by what's going on with their movement." 102 The Portland police appeared to be out of touch and unable to keep the black community unharmed from these white supremacist militants.

These three incidents bookended a violent and raucous decade of overt racism in Portland, Oregon. As Langer has documented, this was a city filled with racist tendencies just under the surface, ready to boil over at a moment's notice. ${ }^{103}$ This was the environment in which Moose was policing. These were the attitudes he faced every day as he policed the streets of Portland.

It would, of course, be instructive to read Charles Moose's take on these incidents - in his own words, describing what we may interpret to be examples of institutionalized police racism towards Portland's black community. And the record does contain some data on his interpretation of one of these significant racial events from the 1980s, the opossum incident at The Burger Barn.

Moose described the opossum incident, and pointed out that at that moment, the restaurant was open, and there were indeed diners inside. Moose added that Chief

102 Barnes C. Ellis, "Skinhead Violence Surges In Wake of Seraw Killing," The Oregonian, 12/24/1988, A 01. ${ }^{103}$ Langer, A Hundred Little Hitlers, 218. 
Bruce Baker terminated the officers, and the black community felt that was an

appropriate response. However, he said, inside the bureau, officers held marches and took a vote of "no confidence" against Chief Baker.

Moose was not terribly sympathetic with the type of establishment that Powe, an African American, was running. When Moose writes about the Burger Barn, he defines it as one of the "hot spots" on Union Avenue. He also notes that "there was all kinds of criminal activity there, night and day - drugs, illegal drinking, illegal gambling and all the violence that goes along with those activities." ${ }^{104}$ But he does not let the Portland police officers off the hook.

Moose delineates the Burger Barn possum incident, and the resulting "atmosphere," as the specific time that he made sergeant. He says the department at that time was marked with "general instability," and notes that it was also "an atmosphere of thinly veiled hostility to blacks." ${ }^{105}$ It is quite instructive to keep these three events in mind, memories from Portland's dark and racist decade of the 1980s, as we examine Moose's arrival on, and professional development within, the Portland Police Bureau.

\footnotetext{
${ }^{104}$ Charles Moose and Charles Fleming, Three Weeks In October; The Manhunt For The Serial Sniper (Waterville, Maine: Thorndike Press, 2004), 299. Former PPB Detective Don DuPay also writes about The Burger Barn - but from the 1960s, when he was in the North precinct. DuPay writes that there was illegal gambling going on in the place, but that the PPB let then continue to run their games. "The owners and their friends never got into any trouble or made any problems, which accounted for our leniency." The Burger Barn was open all night, and Portland's cops almost never paid for their cheese burgers in that era. Dupay, Behind The Badge In River City, 119, 120.

105 Moose and Fleming, Three Weeks In October, 301.
} 
The next chapter will examine Moose's career and a few of the tribulations he faced to become Portland's first African American police chief. 


\title{
Chapter 3 - The Rise of Charles Moose within the Portland Police Bureau
}

\author{
"I had no consciousness of black people in law enforcement."170
}

-Charles Moose.

To some degree, the Portland Police Bureau has been revolutionary in expanding diversity on the police force - particularly in adding women to the ranks in rather innovative ways. Several women Portland police officers rank as established "firsts" in several categories. While there is some historical debate about the specifics, Lola Baldwin is generally regarded as the first woman police officer in the nation, and certainly was the first female "professional" (paid) police officer with her hiring in 1908. ${ }^{171}$ Penny Harrington was appointed Portland's first female chief of police by Mayor Bud Clark on June 2, 1986. ${ }^{172}$ This was a huge step forward when compared to the rest of the nation, where women were rarely actual "crime fighters" in this very male dominated profession. ${ }^{173}$ But in other realms, such as having a racially diverse

\footnotetext{
${ }^{170}$ Charles Moose and Charles Fleming, Three Weeks In October; The Manhunt For The Serial Sniper (Waterville, Maine: Thorndike Press, 2004), 165.

${ }^{171}$ Historian Gloria E. Myers calls Baldwin, "the first woman hired by an American municipality to carry out regular enforcement duties." Gloria Myers' A Municipal Mother; Portland's Lola Greene Baldwin, America's First Policewoman, (Corvallis: Oregon State University Press, 1995), 1. Chicago's Marie Connolly may have been the first with her swearing in in 1891 as a Detective Sergeant with the Chicago Police department.

172 Charles Moose, "The Theory and Practice of Community Policing: An Evaluation of the Iris Court Demonstration Project" (PhD Diss., Portland State University, Studies, 1993), 68.

${ }^{173}$ Mitchel P. Roth, Crime and Punishment; A History of the Criminal Justice System, (Belmont, CA: Thompson Wadsworth, 2005), 285.
} 
force, reflective of the population of the city, Portland has been quite lagging behind its municipal peers for decades.

Historians of law enforcement have located black officers as members of law enforcement bureaus in Chicago and Cincinnati, as well as some other northern cities, as far back as the 1870s. ${ }^{174}$ As one might expect from Oregon's exclusionary laws, Portland lagged behind this standard for some decades. The first black officer on the Portland police force was a gentleman named George Hardin, who was hired in 1894 as a patrol wagon driver. ${ }^{176}$ Hardin served with the bureau for a few years, when he then became the first black Multnomah County Sheriff's deputy. In a 1975 interview, his wife, Ruby Maddox, said “he certainly didn't have any trouble in the sheriff's office. He was thought just as much of as any of the other deputies. They (white deputies) used to come by here and visit him all the time. There was no prejudice in the department."177

In 1946 Charles Duke became the first black officer hired by the Portland Police Bureau in the twentieth century. ${ }^{178}$ In World War Two, Duke had been a first lieutenant in the

\footnotetext{
${ }^{174}$ Roth, Crime and Punishment, 149.

176 “\#ThrowbackThursday Officer Charles H. Duke," Portland Police Facebook page. Accessed 4/5/2016. https://www.facebook.com/portlandpolice/p osts/10151846906045904 See also Gayle Karol, "Dec. 11, 1946: Almost the first black Portland police officer," The Oregonian, 12/05/2008 Accessed $5 / 20 / 2016$ http://www.oregonlive.com/ospecials/blackhistory/index.ssf/2008/02/dec 111946 almost the first b. $\mathrm{html}$ The Oregonian article and bureau folklore have Hardin serving with the PPB until 1915, but historian JD Chandler maintains that Hardin severed for just a few years, and was then a bartender and a teamster for many years until he was hired by the county (conversation with JD Chandler, 4/27/2016).

177 Steve Erickson, "'Pioneer' Portland blacks recall bleak early years," The Oregonian, 3/30/1975, Pg. B 1. Ruby Maddox was born in Brookville, Kansas in 1888 and came to Portland in 1918, when she said there were about 1,000 blacks in the city. She married Hardin in 1921.

${ }^{178}$ Gayle Karol, "Dec. 11, 1946: Almost the first black Portland police officer," The Oregonian, 2/5/2008, accessed online, 4/5/2016.
} 
100th Fighter Squadron of the 332nd Fighter Group, or more popularly known as the Tuskegee Airmen, where he served for a year in Italy. ${ }^{179}$ Ignoring Hardin's earlier "first" designation, under a headline of "Negro Starts Police Duties," in 1946 The Oregonian incorrectly identified Duke as "the first Negro civil service member of the Portland police bureau."180

Police Inspector James Fleming called Duke a "high type citizen." He noted that Duke had done well in his interviews and examinations and "expressed disappointment" that another "Negro" had not done as well as Duke, as the department would have liked to have had a pair of African Americans in the prowl car in the Albina District. ${ }^{181} \mathrm{Dr}$. DeNorval Unthank, president of the Portland Urban League, heralded Duke's appointment. In a letter commending Chief Leon V. Jenkin's selection of Duke, Dr. Unthank said, "Negroes in Portland, along with all democracy-loving citizens recognize this as a progressive step in law enforcement, which is long overdue." Dr. Unthank's letter then took a dark turn, as he shared with the reader the overtly racist environment that Duke would find himself operating in: "This appointment looms the more important when we recall the recent brutality and inefficient policing which has been inflicted upon the Negro community by special officers who seem in no way qualified to hold the posts to which they have been assigned by city officials." While excerpts of Dr.

http://www.oregonlive.com/ospecials/blackhistory/index.ssf/2008/02/dec 111946 almost the first b. $\underline{\mathrm{html}}$

179 "Negro Starts Police Duties," The Oregonian, 12/11/1946, 12 (?)

180 "Negro Starts Police Duties," 12

181 “Negro Starts Police Duties," 12 
Unthank's letter were printed in The Oregonian, these words were buried on page 21 of the Portland daily. ${ }^{182}$

Black police officers remained anomalies on the Portland police force for years thereafter. Retired Portland Police Officer Don DuPay recounted that the Portland Police Bureau in 1962 had "only a few black officers on the force. They were usually hidden away on the night shifts as jailers or working the radio dispatch. This was how the bureau preferred to assign black officers at the time. It always seemed to me that the bureau wanted to keep them out of sight. And they did."183

All of this started to change when Charles Moose came to Portland in 1975. Starting at the bottom of the ladder as a patrolman, Charles Moose became sergeant in 1981, lieutenant in 1984, captain in 1991, and deputy captain in $1992 .{ }^{184}$ He then became Portland's first black police chief. At the time of his 1993 appointment, he became Portland's thirty-eighth police chief, and its youngest chief at age thirty nine. ${ }^{186}$ The evolution of his career, and a few specific incidents during his tenure as chief, affords the reader an opportunity to consider race and policing in the Pacific Northwest in a very unique perspective. This background will help provide depth to the main examination in this essay -that Charles Moose was selected to represent the changing,

\footnotetext{
182 “League Praises Jenkins' Action,” The Oregonian, 12/13 (15?) 1946, 21.

183 DuPay, Don. Behind the Badge in River City; a Portland Police Memoir (Portland: Oregon Greystone Press, 2015), 23.

${ }^{184}$ Rachel Zimmerman, “Guess Who's Coming To Power?” Willamette Week, 7/22-7/28/1993, 14.

186 Zimmerman, “Guess Who's Coming To Power?” 12.
} 
diverse police department, and was afforded the opportunity to expand his theories on community policing.

Charles Alexander Moose was born in August of 1953. His birthplace was New York City, but his middle-class family soon moved back to his father's home state of North Carolina, to the city of Lexington. ${ }^{187}$ Lexington was a segregated town. The movie theater had separate entrances and separate services. The black viewers of the film sat in the upper part of the theater, without candy or popcorn concessions, above the white auditorium. ${ }^{188}$ All of the restaurants in town had separate dining rooms.

Moose explained that "my parents made sure that I understood things like that. They didn't tell me why this was the way it was. But they made sure I understood it was important. You used this door, not that door. You drank from this drinking fountain, not that drinking fountain. There were certain neighborhoods that you stayed out of, certain places you stayed away from. These were survival tips." ${ }^{189}$ And when things were not always as crystal clear as he described, Southern whites would make the restrictions clear. Moose experienced racism and segregation as a child first hand when he was told at a hamburger stand, "We don't serve niggers here."190

Moose finished high school and went on to college in his home state. He studied American history at the University of North Carolina at Chapel Hill. His original intention

\footnotetext{
187 Moose and Fleming, Three Weeks In October, 82.

188 Moose and Fleming, Three Weeks In October, 99.

189 Moose and Fleming, Three Weeks In October, 100.

190 Moose and Fleming, Three Weeks In October, 110.
} 
was to pursue a career in law, and become a defense attorney. But in the fall of 1974, a recruiting team from the Portland Police Bureau was visiting schools in Tobacco Row, looking to enlist minority candidates in the PPB. Moose applied for the position, passed the initial tests, and was offered a job in February of $1975 .{ }^{191}$ While his intention still remained to become a lawyer, he felt at the time that a few years as a police officer could only bolster his depth of knowledge. Upon graduation, Moose drove to Portland, Oregon.

In the later half of the 1970 s, Moose was a beat officer. He noticed a few things right away. The first was that black Portland citizens, who were victims of crime, "looked like me," and needed help. ${ }^{195}$ The second observation that Moose had was also quite instructive towards his development. He felt that "the police were not the bad guys. The criminals were the bad guys. But the police were not working very hard in the black community. Someone needed to help these people, and the police were not really doing all they could."196 Moose realized that the police could do more to affect these black Portland communities. He began that change.

In looking back at his service in Portland, Moose wrote, "At the time of my promotion to sergeant, I had already reached the highest level ever reached by an African-

\footnotetext{
${ }^{191}$ Brien R. Williams, Interviewer. "Oral History Interview, Charles A. Moose, 9/9/2012." National Law Enforcement Museum.

195 Moose and Fleming, Three Weeks In October, 16.

${ }^{196}$ Moose and Fleming, Three Weeks In October, 16.
} 
American in the city of Portland. History did not offer me a lot of hope. I had no reason to believe I had a shot at serious advancement in this kind of department."197

In some ways, Moose says that being black gave him a unique advantage in his career. "It may have made it easier for me to think about ideas like community policing and a holistic approach to protecting citizens from crime. I had a way of relating to the victims and the criminals that maybe the white police officers around me didn't have." 198 Moose had an opportunity to apply his developing theories on community policing directly inside the community that he served, the community that he identified with as a black Portlander.

A much more detailed examination of the theories of community policing could be written by future scholars, and the subject deserves much more ink than can be afforded in this survey of Chief Moose's career. Moose became recognized as an innovative proponent of the theory, and indeed a nationally-celebrated advocate of the approach. Thus, a brief examination of the principles behind the theory, and Portland's unique place in the development of community policing, may provide some necessary context.

As Historian Michael Roth has examined, in the 1980's several urban police departments began experimenting with community policing. Roth labels this method of policing as a return "to an earlier style when police walked a beat or foot patrol and

\footnotetext{
${ }^{197}$ Moose and Fleming, Three Weeks In October, 302.

${ }^{198}$ Moose and Fleming, Three Weeks In October, 513.
} 
maintained intimate contact with the area they served." Roth's characterizes policing before this new approach as being reactive to crime, and community policing as a more proactive method. ${ }^{199}$ Roth's view of community policing (and a troupe supported by others) sees the officer coming out of the police car and thereby strengthening police ties to the community. While crime may not necessarily statistically decrease, the fear of crime declines and community neighbors feel safer. ${ }^{200}$ Portland's commitment to community policing, while unique, should not be viewed in a vacuum. ${ }^{201}$

The Portland "birthdate" of community policing is generally regarded as 1989 or 1990, and is typically attributed to Chief Tom Potter. ${ }^{202}$ A February 1993 Oregonian article (when Moose was deputy chief of police) described community policing as "a public/police partnership that places a premium on prevention." ${ }^{204}$ At the time, Chief Potter said, "I tout community policing as the Peace Corps of the '90s," which may have struck some as something odd for a law enforcement officer to say. ${ }^{205}$ As chief, while addressing the City Club of Portland in August of 1993, Moose defined the term by stating that, "In some ways, people seem to be, when they want to be, confused about

\footnotetext{
199 Roth, Crime and Punishment, 338.

200 Roth, Crime and Punishment, 312.

${ }^{201}$ In an April 1999 study, the Urban Institute found that in 1995, 70\% of law enforcement agencies in thirty cities stated that they practiced some form of community policing. Some of these cities included Austin, San Diego, Chicago and Portland. City Club of Portland, "Community Policing in Portland," 2003, 50 -53 .

202 Scott Learn, "New Police Priorities Set Out In Strategic Plan Get Approval By Council," The Oregonian, 10/3/1996, E 04. Willamette Week says 1990. See Maureen O’Hagen, “Hope or Hype," Willamette Week, 9/27-10/3/1995, 20.

${ }^{204}$ Editorial, "Bridging Troubled Waters," The Oregonian, 2/28/2993, K 02.

205 Erin Hoover, "Standing on Principle," The Oregonian, 10/23/1994, A 01.
} 
community policing. Community policing says that police and the citizens work together to solve problems. It doesn't need to be any more complex than that." ${ }^{206}$ In 1999 , The Oregonian identified the term to mean, "solving problems before they erupt into crimes." 207

Moose's 1993 dissertation provides a little more detail on his thoughts on the subject. In fulfillment of his doctorate in Urban Studies at Portland State University, Moose's work was titled "The Theory and Practice of Community Policing: An Evaluation of the Iris Court Demonstration Project." Calling it a "new direction for policing," Moose described community policing as involving "the proposal that police should broaden their mission, extending traditional tasks of law enforcement and order maintenance in ways whereby police would promote the common good, serve as community social workers as well as law enforcers, and so on." ${ }^{208}$ Moose continued to explain that "the police can both broaden their mandate and become more effective insofar as they engage in cooperative and interactive relationships with the communities they serve." 209 This is a very different relationship with the community than the one that Sergeant Moose described as occurring in his early policing efforts in Northeast Portland in the 1970s and 80s.

\footnotetext{
${ }^{206}$ City Club of Portland, "New Directions For Portland's Police Department." 8/6/1993. https://www.youtube.com/watch?v=eP1UXxiVBqo\&feature=youtu.be

207 Editorial, "Chief Was Never Milquetoast," The Oregonian, 5/28/1999, D 14.

208 Moose, "The Theory and Practice of Community Policing," 3.

${ }^{209}$ Moose, "The Theory and Practice of Community Policing," 3.
} 
Community policing was somewhat theoretical in Moose's interpretation, and certainly a newer concept to some in law enforcement. As he wrote in his dissertation, "because community policing is principally a philosophy rather than a uniform and detailed program, no manual exists that describes, step-by-step, how to implement it."210 But theory could be expressed in some tangible, real-life police craft. Moose said after his involvement with Iris Court that, "simply going in and arresting people and then leaving is not good enough. You have to stay. You have to commit to building up an area, so that they are empowered. So that they can stand alone."211

In a 1992 review, when Moose was the North Precinct commander, Police Chief Potter commended his commitment to community policing. "You were tireless in your drive to lead by example, attending countless community meetings, many during your off duty time. You were successful in establishing partnerships with the community, and took the lead in developing innovative solutions to long standing problems." ${ }^{216}$ In a police bureau that was a national trendsetter in community policing, Moose was an inventive leader in that program.

\footnotetext{
210 Moose, "The Theory and Practice of Community Policing," 8.

211 NBC News, “America Close Up” segment, 6/2/1994

216 “Moose Releases Personnel Records in Advance of Suit," The Portland Skanner, 4/30/1997, 3. Community participants included the Office of neighborhood Involvement, attendees of the Chief's Forums, the Burnside Consortium (now known as Central City Concern), Neighborhood Watch \& Block Captain programs and others.
} 
As police chief, Moose referred to the community as his "customers." ${ }^{217}$ Ever-present in his mind was the fact that the PPB was to work with the community. He wrote that, "we need to remember what our community members desire. We need to remain focused on the little things. We need to make traffic stops for violations and loud music, we need to work street drug dealing, we need to confront people who drink on the street, we need to challenge young people about truancy, curfew and trespassing. The felonies will still be there and we do those extremely well, but the community remains concerned about the order maintenance issues that require us to confront and communicate with people who not only commit crime, but destroy neighborhood livability."218

Moose was sought out due to his established mastery of community policing. In July of 1994, Democratic gubernatorial candidate Dr. John Kitzhaber met with Dr. Moose to discuss these theories in a very unique, but appropriate environment - in the front seat of a Portland police patrol car. After the evening roll call and a tour of the EastSoutheast precinct facility, the two got into the vehicle and toured Portland's neighborhoods. Moose exposed the candidate to "a street level view of community policing." In a press release describing the private meeting, Moose said "crime issues that were seen as only urban problems have now spread to areas across the State. I am happy to have the opportunity to discuss the Portland model of community policing

${ }^{217}$ City of Portland Archives, B/030229, 24-03-36, Subject Files, Police: Mayor's Office, 1993-1998, Box 2, file "The Bulletin," “Chief's Corner," The Bulletin, 10/24/1996.

${ }^{218}$ City of Portland Archives, "Chief's Corner," 10/24/1996. 
with Dr. Kitzhauber [sic]. To impact crime problems, and improve the livability of communities, we must continue to create strong partnerships between cities, counties and the State of Oregon." 219

In March of 1993, Patrick Donaldson, executive director of the Citizens Crime Commission, described Portland as "the envy of the country for its community policing program." He added that "I can't believe that anyone outside the Portland Police Bureau is more knowledgeable about the vision that has been evolving over the last five years than the command staff and rank and file of the Portland Police Bureau."220 Roger Morse, President of the Portland Police Association, said that Portland was "where (community policing) was invented and refined." ${ }^{221}$ Charles Makinney ran the PPB fiscal and records division from 1981 to 1994. In July of 1999, he said, "Portland has one of the best community policing organizations in the country, with cutting edge programs. You have to give him (Moose) credit, because he created the environment for that."222

In September, 1994, Kent Markus, deputy associate attorney general said “There's no doubt that the Portland Police Department has an outstanding reputation around the country, especially recognized for its innovative work on community policing. That's an

\footnotetext{
${ }^{219}$ City of Portland Archives, B/030226, 24-02-15, Subject Files, Police: Mayor's Office, 1993-1996, Police Related Press Releases/Video Tapes, file "July-Oct," “Moose, Kitzhauber To Meet Behind Closed Doors (Patrol Car Doors)," 7/25/1994.

${ }^{220}$ Barnes C. Ellis and Michael Rollins, "Potter to Announce He's Retiring," The Oregonian, 3/10/1993, A 01.

${ }^{221}$ Barnes C. Ellis, "Secrecy Shrouds National Search For Police Chief," The Oregonian, 5/13/1993, D 05.

222 Maxine Bernstein "Moose Closes Out 6-Year Tenure of Achievement, Pitfalls as Chief," The Oregonian, 7/28/1999, A 01.
} 
opinion that is shared not only by the Justice Department but by police departments around the country."223

Moose was acknowledged nationally for his efforts in community policing. In 1995 , he was the recipient of the Federal Bureau of Investigation Director's Community Leadership Award. The annual award recognized "individuals and organizations for their work in reducing the demand for illegal drugs in their communities." 224 In his nomination for the award, the FBI cited "his work in community policing and problem solving in drug affected neighborhoods such as The Iris Court Community Policing Project." Noted was Moose's involvement with Mainstream Program and The Boys and Girls Club, and his service on the Board of Directors for Comprehensive Options for Drug Abusers, as was "the positive impact the chief and his wife, Sandy, have made on the King neighborhood since moving there in 1993."225

The birthplace of Moose's hard work and well deserved recognition was a little North Portland community of Iris Court, one of three demonstration projects selected by the Portland Police Bureau to experiment with a dedicated community policing program.$^{226}$ Iris Court is the "common name" of a 108 unit, public housing complex that was owned

\footnotetext{
${ }^{223}$ Erin Hoover, "Moose Drops Out of Cops Job Selection," The Oregonian, 09/17/1994, A 01. The King neighborhood is in Northeast Portland and will be discussed in greater detail in Chapter Five.

${ }^{224}$ City of Portland Archives, B/030226, 24-02-15, Subject Files, Police: Mayor's Office, 1993-1996, Police Related Press Releases/Video Tapes, file "11/1994-May 1995 News release," "Chief Charles Moose To Receive FBI Reward," 1/12/1995.

${ }^{225}$ City of Portland Archives, "Chief Charles Moose To Receive FBI Reward," 1/12/1995.

${ }^{226}$ It is beyond the scope of this survey to examine the Iris Court development program in too much depth. Indeed, the subject is worthy of a dissertation, much like the one Moose conducted for his studies in 1993. None the less, an introduction into the community policing project may enlighten the reader on Moose's views on the subject.
} 
and operated by the Housing Authority of Portland (HAP), which purchased the property in 1959. ${ }^{227}$ According to Moose's dissertation, in 1961, "Iris Court had virtually all white tenants."228 In 1964, it was reported that Iris Court had experienced some racial skirmishes, and that at that time there were fourteen African American residents and forty whites. ${ }^{229}$ In the 1970 s, HAP purchased some neighboring complexes to add an additional fifty-four units. By this time, the demographic nature of the community had shifted, and the residents of Iris Court were predominantly black.

Adjacent to Jefferson High School, the accepted boundaries for the 1980s Portland Police Bureau demonstration project, were North Killingsworth Street on the north, North Vancouver Avenue on the east, North Commercial Avenue on the west, and North Webster Street on the south. ${ }^{230}$ In 1994, Chief Moose wrote that "Iris Court has long been a primary community policing site for the Portland Police Bureau." ${ }^{231}$ At that time, he wrote that, "The Portland Police Bureau has operated a nationally recognized community policing project at Iris Court for four (4) years. More importantly, we believe we have made Iris Court, and the surrounding community, a safer and more livable

\footnotetext{
227 Moose, "The Theory and Practice of Community Policing," 82.

228 Moose, "The Theory and Practice of Community Policing," 82.

229 Moose, "The Theory and Practice of Community Policing," 82.

230 Moose, "The Theory and Practice of Community Policing," 76.

${ }^{231}$ City of Portland Archives, A2005-004, 0252-01, Mayor Vera Katz Subject Files, Internal Staff Files: Chuck Bolger, 1998-1999, Box 2, file “Constituent letters to Chief of Police Charles Moose," letter from Chief Moose to Denny West, Housing Authority of Portland, 7/20/1994.
} 
place in which to bring up families. We will continue to maintain our commitment to Iris Court, and our valuable partnership with the Housing Authority of Portland." 232

Today, Iris Court is called Humboldt Gardens. It is a very different place than the Iris Court of Charles Moose's era. Home Forward (formerly the Housing Authority of Portland) declares that Humboldt Garden is "a groundbreaking green community of townhomes, flats, and apartments built around a central pocket park." The principle of sustainability is featured on the Home Forward website, noting that Humboldt Gardens was "designed from the ground up with input from the entire community... [and] incorporates a high number of green features such as low-flow showers and toilets, storm water swales, and Energy Star appliances." It also states that the housing units were "developed to replace the badly aging and inaccessible Iris Court apartment complex off Vancouver Avenue in North Portland."233

But in the late 1980s, Iris Court was not thought of as an eco-friendly, green community. Instead, it was identified as a hotbed of drug dealing, open violence, and blatant disregard for police authority. Law-abiding citizens were, as Moose put it, "prisoners within their own homes." ${ }^{234}$ Reinforcing some of his core views on community policing, Moose observed that these law-abiding Portlanders' "sense of

${ }^{232}$ City of Portland Archives, letter from Chief Moose to Denny West, 7/20/1994.

${ }^{233} \mathrm{http}$ ://www.homeforward.org/development/property-developments/humboldt-gardens (DOC $10 / 9 / 2015)$

${ }^{234}$ Moose, "The Theory and Practice of Community Policing," 79. 
powerlessness and abandonment was very damaging, affecting the livability of the
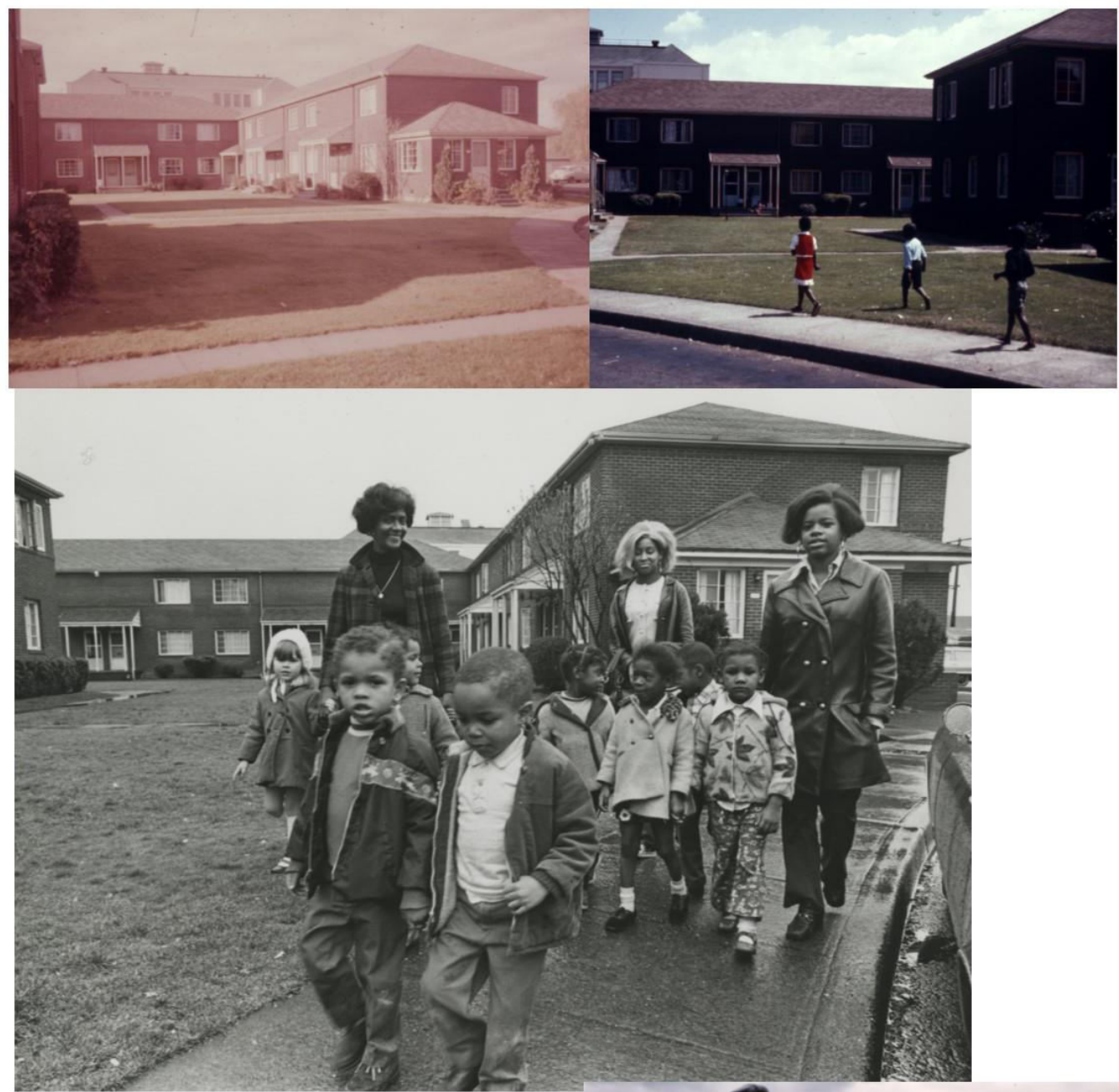

Historic images of

\section{Iris Court}

1961, 1976, 1970 and 1985.

Courtesy of City of Portland Archives and Records, A2001-025.950, 025.951, 025.348 and 025.6

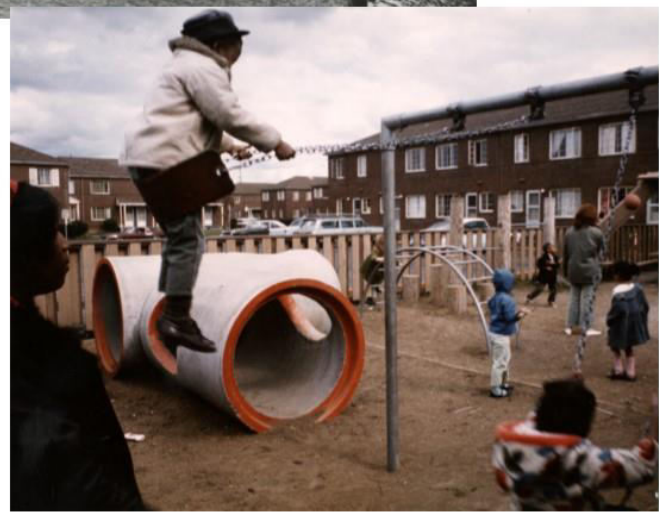


complex and the surrounding Humboldt Neighborhood." ${ }^{235}$ According to Moose, the well-being and desire to interact in a productive manner with neighbors affects the prosperity of the entire neighborhood.

Working with residents, social service providers, and the Portland Police North Precinct, a work group identified goals for the Iris Court Community Policing Demonstration Project: 1) Improve the quality of life of the residents; 2) Reduce fear of crime; and 3) Reduce the actual level of crime. ${ }^{236}$ The order of those priorities seemed noteworthy. Typically, one would associate "reducing the actual level of crime" as a primary function of law enforcement, a priority above all others. But in a sense, the implementation of community policing, in action, no longer at theoretical discussions of academia, was beyond simply arresting criminals who stole VCRs.

And what was "quality of life?" It seems to be such an intangible, amorphous qualifier. In Mooses's dissertation, he writes that it "was to be gauged by the following indicators: income, employment, health and education." ${ }^{237}$ For Moose, job training and nutrition classes would be as important as fighting crime. ${ }^{238}$ Again, this was quite a deviation from the enforcement policies Moose projected throughout North and Northeast Portland in his first ten years of policing.

\footnotetext{
235 Moose, "The Theory and Practice of Community Policing," 79.

${ }^{236}$ Moose, "The Theory and Practice of Community Policing," 89.

237 Moose, "The Theory and Practice of Community Policing," 89.

238 NBC News, "America Close Up" 6/2/1994.
} 


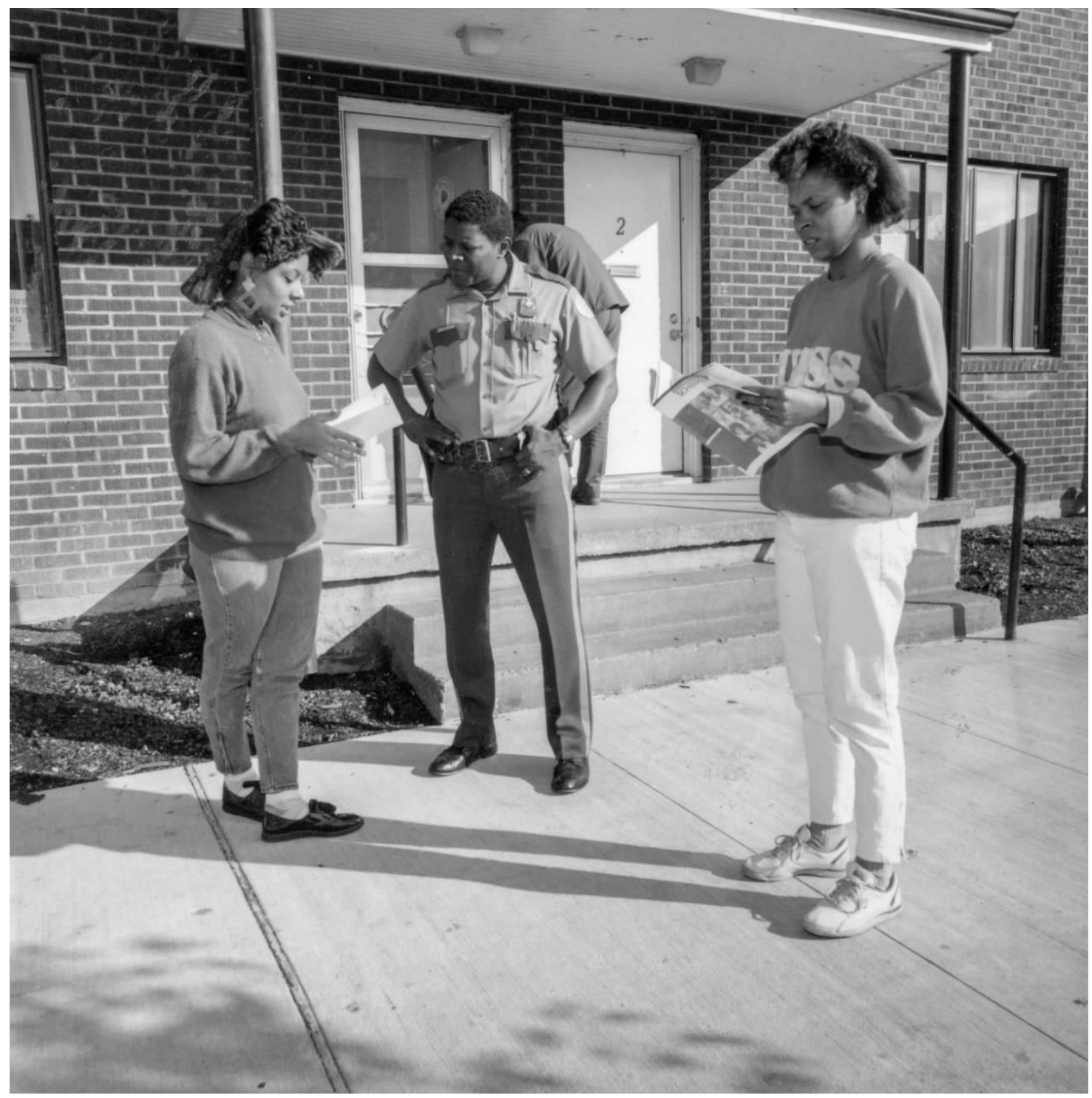

Figure 7 "Lt. Charles Moose hands out job and education information at Iris Court Open House. " Courtesy of Oregon Historical Society, Image bb014323

Moose's plan was to immediately stabilize the dangerous crime levels in the complex.

Once residents were feeling safe again, and no longer seeing themselves as victims, police officers would then direct them to other participating agencies, "in the social 
service fields of employment, health and education." ${ }^{239}$ Moose explained that there was to be an interweaving of human services and the criminal justice system "into a single service delivery team." At the time, Mayor of Portland Bud Clark used a Biblical metaphor for the program, "Police others as you would have others police you. Our officers will move from being crime-fighters to being problem-solvers." 240

Again, it is important to remember that this was a police-led program. According to Moose, "the approach recognized that when a police agency simply responds to calls for service, investigating crimes, and making arrests, sustained reductions in crime do not necessarily occur. The group was advised that unless the police are willing to link up with other public and private agencies, the complicated social problems that often serve as the underlying causes of crime cannot be solved."241 The police officer in a community policing environment, he maintained, was a social worker (in a "first responder" sense of the profession), as much or if not more than she is an enforcer of law.

If the Iris Court complex and the designated area around it stabilized, Moose hoped, "then other police officers, citizens and social service providers may be convinced that this approach is successful and transferable to other problem locations." 242 Iris Court

\footnotetext{
239 Moose, "The Theory and Practice of Community Policing," 88.

240 Thomas Chan, "Community Party Celebrates Community Policing," The Oregonian, 7/29/1990, D 01.

241 Moose, "The Theory and Practice of Community Policing," 85.

242 Moose, "The Theory and Practice of Community Policing," 88.
} 
was a working laboratory for community policing. Moose was all in, and the rest of the city was watching.

The plan was implemented at Iris Court in May of 1990 and concluded at the end of July 1991. In his analysis, Moose concluded that the results were "moderately successful. Reported crime dropped, the fear of crime was reduced, and there were mixed indications that the quality of life for the complex was improved."243 One unexpected product realized in the demonstration was a fifty-five percent decrease in reported crime. Reverend James Jackson, a resident of Iris Court, gave a glowing assessment of the success of the plan when he said, "They straightened out a lot of things. That dope and all that kind of stuff. It was here bad!"244

Moose later reflected on his involvement with Iris Court. "What I discovered was that poor people wanted safety just as much as rich people did - or even more. I discovered that it was wrong to think they were willing to live in a place that was all messed up, just because they had always lived in a place that was so messed up." Moose became an optimist and a proponent of change: "Given a chance, they were eager to participate in an effort to make it better." 245

"The bureau had no intention of hiring minorities."246 -PPB Officer John Frater, 1990

\footnotetext{
243 Moose, "The Theory and Practice of Community Policing," 162.

244 NBC News, "America Close Up" 6/2/1994

245 Moose, "The Theory and Practice of Community Policing," 373.

246 Michael Rollins, "Cadets Focus on Portland Police Pitch," The Oregonian, 4/21/1990, D 01.
} 
In 1981, when Moose became a sergeant, just $5.79 \%$ of the bureau was composed of minorities. ${ }^{247}$ Moose details a little of this disparity in his book when he writes of the 1980s, the decade previously examined as "pivotal" in Portland's race relations. "It wasn't a great time to be a black police officer in Portland. For one thing, there weren't very many of us." 248 Moose related that at that time the African-American population in the city was under ten percent, and the number of African-American police officers in the Portland Police Bureau was under five percent of the total force. A bureau with over 800 officers included less than forty black police men or women. The department employed eighty female officers, as the bureau had made recruiting women a priority. Moose sums up his statistics by concluding that "the department hadn't done so well with minorities."249

Moose expounded on the environment at the time: "I think then maybe that was backed up by the fact that there were some injustices inside the police department, in terms of subtleties with regard to discrimination, things like a composite of an AfricanAmerican male would come out in terms of someone that we wanted to find for a criminal activity, and some of the white officers would come up to you and hold a composite next to your face and make little comments about, 'Well, he kind of looks like you.' Those kinds of things. It was one of those situations where, no, we're together and

\footnotetext{
${ }^{247}$ Maureen O'Hagen, “Black and White," Willamette Week, 5/7/1997, Pg. 14.

248 Moose and Fleming, Three Weeks In October, 367.

249 Moose and Fleming, Three Weeks In October, 367.
} 
we're both trying to make this a better community, but these were the kind of things

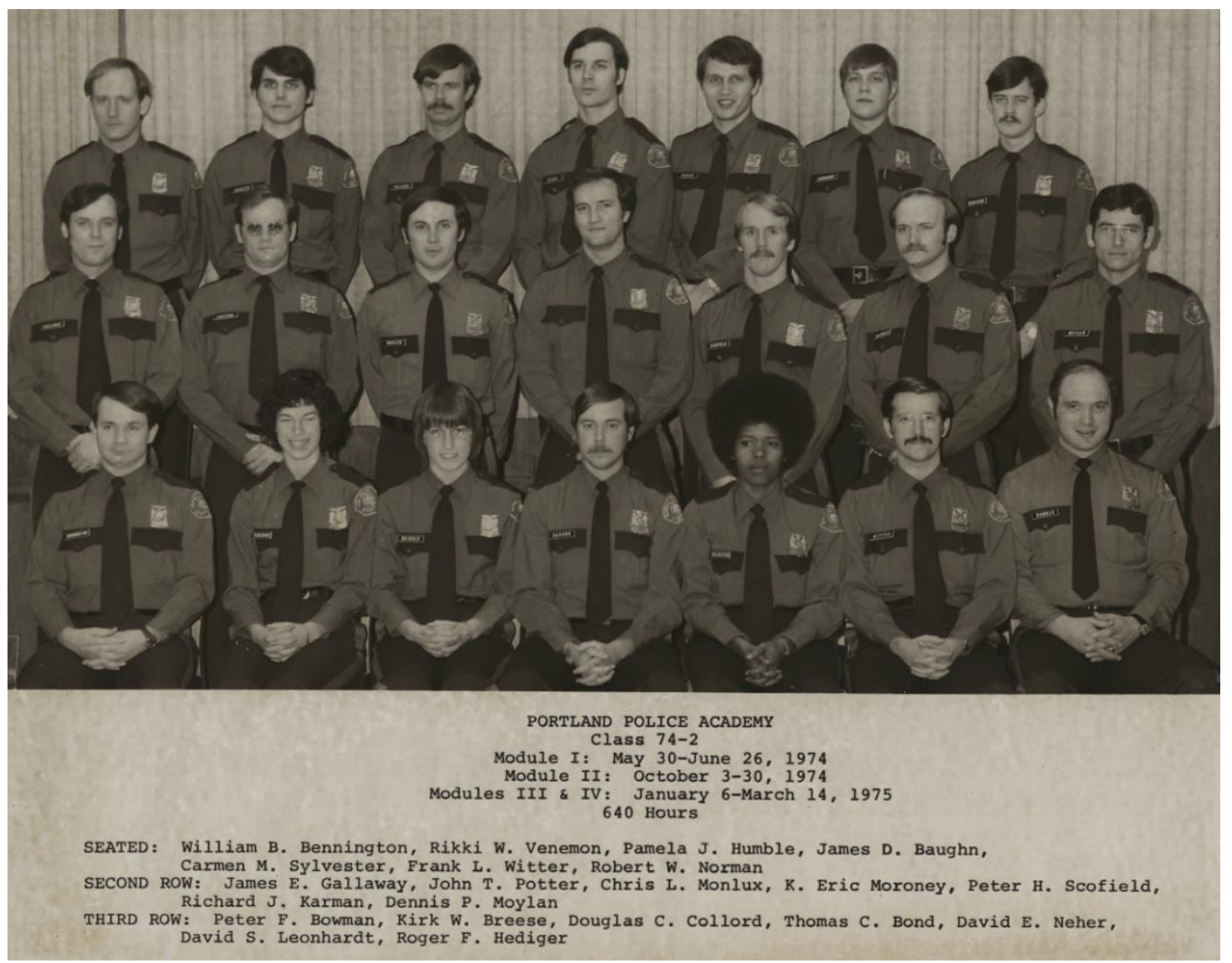

Figure 8 March 1975, Police Academy Class City of Portland Archives and Records, A2003-001.68 that would take place in the locker room, in the briefing rooms, and then certain namecalling, not particularly to you, but about the people that you may be looking for or 
someone that you arrested. So you could see that there were some parts of the organization that needed improvement."250

In early 1990, the PPB had 762 sworn officers. Twenty-one were black, and only one black man had reached the rank of lieutenant - Charles Moose. ${ }^{251}$ Three of the black officers were interviewed by Oregonian reporter Michael Rollins, who wrote that, "all three Portland officers said overt racism from other officers was not a problem for them in the bureau. If white officers do have a racial problem, they wisely keep it to themselves or simply avoid contact with black officers. The problem, PPB Officer Larry Anderson said, is that with the limited number of black officers, the bureau can simply ignore race as an issue. And that, he said, "can be just as painful as a racial slur." 252 Moose later wrote that at the time the department's hierarchy was "very white, very male, very conservative."253

At the time that Tom Potter became chief in 1990, black officers had been organizing meetings to develop a lawsuit against the city, due to the environment of the workplace. Potter had asked them to abandon their plans and give him a chance to make reforms. ${ }^{254}$ Several black officers were promoted to detective or sergeant. Most recognizable to Portland residents would be Sgt. Derrick Foxworth, who became the

\footnotetext{
250 Williams, "Oral History Interview, Charles A. Moose, 9/9/2012."

251 Michael Rollins, "Cadets Focus on Portland Police Pitch," The Oregonian, 4/21/1990, D 01.

252 Rollins, "Cadets Focus on Portland Police Pitch," D 01. Officer Larry Anderson was identified in the article as being black.

253 Moose and Fleming, Three Weeks In October, 347.

254 Michael Rollins and Tom Hallman Jr., "Potter Legacy Includes Divided Police Bureau," The Oregonian, 3/14/1993, A 01.
} 
bureau's public information officer - the "face" of the PPB. Due to Potter's promotion of blacks and minorities, Moose (a deputy chief at the time) and others believed that Potter truly was attempting to create a more diverse police force, so diverse, in fact, that Chief Potter received a standing ovation at an appearance at the Oregon Black Law Enforcement United meeting. 256

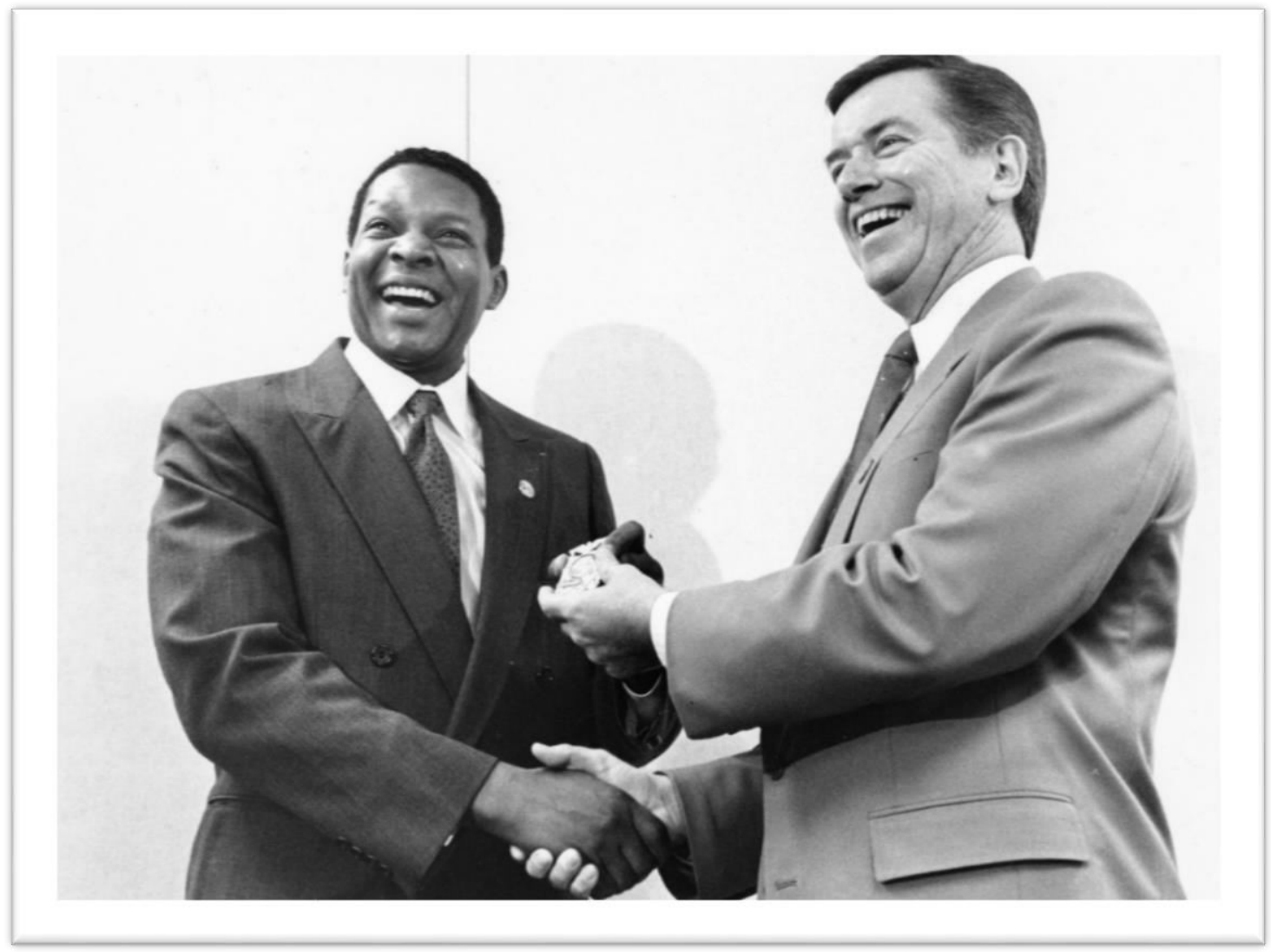

Figure 9 Charles Moose and Tom Potter. Courtesy of Oregon Historical Society, Image bb013831

The new era of Potter's reign found the Portland Police Bureau poised for transformation. The force was top heavy with many commanders who had joined the

${ }^{256}$ Rollins and Hallman, "Potter Legacy Includes Divided Police Bureau," A 01. 
bureau in the mid-1960s. Many of those veteran police officers were eligible for retirement within a year or two. ${ }^{257}$ Some transformations had already been taking place - by the end of September of 1990, of the sixty-three officers hired, two were black, and as The Oregonian stated, the new officers included "five Hispanic-Americans, two AsianAmericans and two American Indians." Six of the new hires were women. ${ }^{258}$ Portland Police Chief Richard Walker (who Potter succeeded as chief) said that the bureau that was traditionally made up of white men who were military veterans was giving way to people who more closely resembled the fabric of Portland. ${ }^{259}$ According to a reporter in The Oregonian, the bureau planned to hire several hundred more minorities in the first few years of that decade. ${ }^{260}$

Still, creating a racially-sensitive police force was not as easy as hiring a few black police officers. These officers needed to police in Portland, including in the predominantly black neighborhoods, and that was not always a simple situation. "The black officer [in the black community] is viewed as a traitor by some," PPB Officer Larry Anderson was quoted as saying in the newspaper. ${ }^{261}$ Officer Anderson was speaking from his own professional experience. Black officers faced friction from both the black communities they policed in and from the largely white bureau that they policed with.

\footnotetext{
257 Michael Rollins “New Era of Community Policing Looms For Portland Force," The Oregonian, 9/30/1990, C 12.

258 Rollins "New Era of Community Policing Looms For Portland Force," C 12.

259 Rollins “New Era of Community Policing Looms For Portland Force," C 12.

${ }^{260}$ Rollins “New Era of Community Policing Looms For Portland Force," C 12.

261 Rollins, "Cadets Focus on Portland Police Pitch," D 01.
} 
In 1990 Michael Rollins, an Oregonian reporter, wrote that one officer, Pat Renfro, told him that, "unfortunately, police are viewed as tools of the oppressor, especially to disenfranchised blacks." Police are viewed as people "who make drug busts, drink coffee, drive fast and beat people up," Renfro said." 262

The history of the PPB had encouraged this perception. Moose saw that in 1970's Portland "being a policeman, at that time, in that place, wasn't at all cool." 263 Moose added that he was alienated in Portland's black community. He said, "In the black community generally l'd hear a lot of negative things about being a policeman. There was a lot of hostility towards the police. I got called a "Tom," and an "Uncle Tom," more than once. There were just a lot of people who didn't want to have anything to do with the police." 264 Moose wrote that, "there's a perception in the black community that if you are a police officer you are automatically an Uncle Tom, or some kind of traitor to your people... Most African-Americans see the police as part of their problem, and not part of their solution."265

He saw this first hand early in his Portland policing career. "Most of the officers that worked the avenue (Union or today's Martin Luther King Jr. Avenue), and who ran the avenue cars, were white. And most of the criminals and suspects they arrested were black. This led to a natural hostility between the citizens and the police. There is no

\footnotetext{
262 Rollins, “Cadets Focus on Portland Police Pitch,” D 01.

263 Moose and Fleming, Three Weeks In October, 193.

264 Moose and Fleming, Three Weeks In October, 193.

265 Moose and Fleming, Three Weeks In October, 514.
} 
doubt in my mind that the police behavior exacerbated that hostility." ${ }^{266}$ And Moose was correct in his assessment. In a span of just six months starting in October of 1974 and ending in March of 1975, Portland Police Bureau officers shot and killed six young black men. ${ }^{267}$

"The city of Portland during the 1980s was a city without unity. The African American community was disenfranchised."268

-Charles Moose

During the "Don't Choke 'Em Smoke 'Em" period, "it wasn't a good time to be a black police officer," according to Moose. ${ }^{269}$ He described the bureau at that time as being "in bad shape. It was demoralized, angry and dispirited."270

In late March of 1991, Lieutenant Moose advanced to the rank of Captain. He was the first black captain in the history of the Portland Police Bureau. The only other non-white captain the PPB had ever had was a Native American named Bill Taylor, who retired in 1980. ${ }^{271}$ At the time of Moose's promotion, he was one of thirteen captains in the PPB. Lieutenant Glenn Miyamoto, of Japanese descent, was passed over (along with three white officers) at the time of Moose's selection. Lt. Miyamoto said that Chief Tom Potter "did this for political reasons. The political motive is to give the black community the

\footnotetext{
266 Moose and Fleming, Three Weeks In October, 298.

${ }^{267}$ Author unknown, "The Suspects Who Died," The Oregonian, 5/9/1985, D 2. In our current era with a national "Black Lives Matter" movement rightfully angry at police officers killing young black men, it is poignant to remember how dangerous it was to be black in 1970s Portland.

268 Moose and Fleming, Three Weeks In October, 374.

269 Moose and Fleming, Three Weeks In October, 366.

270 Moose and Fleming, Three Weeks In October, 381.

${ }^{271}$ Michael Rollins “Asian-American Claims Bias As Police Promote Black," The Oregonian, 4/2/1991, B 03.
} 
first black captain." 272 Under civil service policies, Chief Potter was able to select from the top five finalists of the promotion exam. This process was termed the "rule of five." ${ }^{273}$ Miyamoto scored first in the exam, Moose fifth, with the white officers in the middle. Interviews conducted in the process "included questions on community policing that covered both its management within the bureau and how the new captain would use the new techniques with citizens." ${ }^{274}$ Race was also a factor.

In a "strongly-worded letter" that he sent to Chief Potter, Mayor Bud Clark, and the city commissioners, Miyamoto wrote that "it is my perception that you have rejected me for the promotion based on race." ${ }^{275} \mathrm{~A}$ few days after he wrote the letter, Miyamoto said that in the past month he had begun to hear from fellow officers "that I was a Japanese American and that Asians don't have political clout.".276

Moose had a different interpretation of his promotion over Miyamoto. Moose wrote that "what was left out of that story was how long it had taken me to become captain. Leaving aside any question of which of us was the "right minority," I had been a lieutenant for nine years. For nine years I had been trying to get promoted. For nine years I had been taking that test." 277

\footnotetext{
272 Rollins “Asian-American Claims Bias As Police Promote Black,” B 03.

${ }^{273}$ Rollins and Hallman, "Potter Legacy Includes Divided Police Bureau," A 01.

274 Rollins "Asian-American Claims Bias As Police Promote Black," B 03.

275 Rollins "Asian-American Claims Bias As Police Promote Black," B 03.

276 Rollins “Asian-American Claims Bias As Police Promote Black," B 03.

277 Moose and Fleming, Three Weeks In October, 368.
} 
Moose felt that other nefarious and racist attitudes had been holding him back as

well. He felt that his interracial relationship with a white woman hampered his

professional development. "Later on, when I was stuck in the lieutenant's job, and for

nine years couldn't seem to make captain, it occurred to me many times that this was

part of the problem. I was always sure that marrying Sandy had hurt my chances for

advancement, but I could never prove that was the case."278

${ }^{278}$ Moose and Fleming, Three Weeks In October, 347. Nor would that be his last experience like that. Moose expanded on the topic when he wrote about when he was a candidate for Chief of Police in Jackson, Mississippi in 1990. When he went down for an interview he was hosted at a hotel that was flying the Confederate flag. He says that after attending a Christmas Party for the candidates, he met the other top candidates, both of whom had black wives. He fell out of contention after the party. In his book, Moose relays that a reporter from the Jackson-Advocate quoted a member of the mayor's hiring committee as saying, "Moose walked in with a blonde-haired, blue-eyed white wife and that killed any chances he had of becoming police chief here... This is still Jackson, Mississippi." (Pg. 508). 


\section{Chapter 4-Becoming Chief of Police Charles Moose}

Again, it may be instructive to draw the reader's attention back to the racial context of the era. Key incidents include the dead opossums lying in front of The Burger Barn in 1981 and the tragic 1985 death of Tony Stevenson at the hand of the police. In addition, Portland witnessed the wave of activity that resulted from various white pride youth movements, including the bludgeoning death of Ethiopian immigrant (and Portland State University student) Mulugeta Seraw in November of 1988. While the first two incidents were direct results of police action, the skinhead movement was not. Nonetheless, there was a perception that even though the police were not involved, they were unable or unwilling to police racist displays and violent activity committed in Portland. The situation had spun out of control, and the bureau appeared to be unable to contain it. Because of the racial atmosphere, by September of 1990 there was, according to the local newspaper, "a groundswell of behind-the-scenes support for a dynamic new chief to lead the bureau into the 1990s." 310

In March of 1993, Multnomah County District Attorney Michael Schrunk expressed the importance of a proper police chief appointment. "The man or the woman who is the chief of police has an awful lot to do with setting the tone of the community - often more so than elected public officials." ${ }^{319}$ In March of 1993, when Chief Tom Potter

\footnotetext{
310 Michael Rollins “New Era of Community Policing Looms For Portland Force," The Oregonian, 9/30/1990, C 12.

${ }^{319}$ Barnes C. Ellis and Michael Rollins, "Potter to Announce He's Retiring," The Oregonian, 3/10/1993, A 01.
} 
retired, the bureau employed more than 900 officers and held a budget of over $\$ 76$ million, which accounted for one-third of the city's general fund. ${ }^{320} \mathrm{~A}$ movement was sweeping through the city to bring real change to the largest bureau in Portland.

Portland was lagging the rest of the nation in terms of having black citizens at high levels of government. The chief of police position was a prime example of that racial disparity. As law enforcement historian Mitchel Roth observed, "By the end of the 1980s, major American cities boasted African American police chiefs, including New York City, Atlanta, Chicago and Houston." ${ }^{321}$ New voices were being brought to the conversation of policing across the country. It was well past time for Portland to make a similar appointment.

When news of Potter's retirement became known, Moose was considered a top candidate. "Moose is seen as the closest the bureau may ever come to a cop's cop who still fulfills the bureau's new citizen-agenda. He was the force behind some of community policing's most visible and successful efforts in North Precinct," The Oregonian reported. ${ }^{322}$ The Portland Skanner echoed this statement eight weeks later when their editors wrote that Moose "knows the community, he knows the city and he knows what kind of police force the city wants. ${ }^{1323}$ The Skanner challenged the city to

\footnotetext{
${ }^{320}$ Ellis and Rollins, "Potter to Announce He's Retiring," A 01.

${ }^{321}$ Mitchel P. Roth, Crime and Punishment; $A$ History of the Criminal Justice System, (Thompson Wadsworth, Belmont, CA, 2005), 312.

322 Michael Rollins and Barnes C. Ellis, "Wanted: New Portland Police Chief," The Oregonian, 3/11/1993, A 16.

${ }^{323}$ Author Unknown, "Moose for Chief," The Portland Skanner, 5/5/1993, 4. The Skanner is a black newspaper.
} 
select Moose when it declared in an editorial that "Mayor Vera Katz has been handed a golden opportunity to prove that she means what she says about diversity." 324

Moose's “Cop's Cop" reputation certainly didn't hurt his prospective candidacy. Just before he was being considered to replace Tom Potter as chief, Moose was asked what he would miss about being a captain. Moose responded that it was "standing in front of men and women at a roll call and telling them to go out and take back the streets." 325

Richard Brown, co-chairman of the Black United Front, was a member of the Chief's Forum. As a Forum member, he helped interview the candidates for chief. He stated to a reporter that he was satisfied with the process, and also, that as far as he remembered, this was the first time that the mayor's office had sought such "broad input." 327

At Mayor Katz's June 29, 1993 announcement appointing Moose as chief of police, Urban League of Portland President Darryl Tukufu said “African-Americans can aspire to be the chief of police, fire chief, the mayor and even the president. This is a milestone for Portland." ${ }^{331}$ Lolenzo Poe of the Coalition of Black Men echoed the sentiment. "I'm ecstatic. It's a tremendous day. It tells me that the input of the community has paid off." ${ }^{332}$ The Skanner called the appointment "the right move at the right time," and

\footnotetext{
324 Author Unknown, "Moose for Chief," 4.

325 Ellis and Rollins, "Potter to Announce He's Retiring," A 01.

327 Nanine Alexander, "Black Leaders Rate Katz's Credibility," The Oregonian, 6/24/1993, C 08.

${ }^{331}$ Michael Rollins and James Long, "Moose Will Command Police," The Oregonian, 6/26/1993, A 01.

332 Michael Rollins and James Long, “Moose's Dedication Wins Katz," The Oregonian, 6/26/1993, A 01.
} 
declared that Katz "should be applauded for taking a long step towards improving relations between the police bureau and North/Northeast Portland."333

Willamette Week said that "though Katz maintains that the job could have easily gone to some other qualified candidate, choosing Moose was certainly a shrewd political move for several reasons: An internal choice symbolized her confidence in the bureau, a black chief lent currency to her commitment to diversity, and, more than anything else, Moose's philosophy most resembled that of his wildly popular predecessor, Tom Potter." 334

Moose echoed those statements as well when he reflected on why Katz chose him for the position. Long after he was chief, Moose said that Katz told him that she had chosen him because he was from within the force and would have the respect of the rank and file. He was young enough to have been on the beat, not that long ago. She also wanted someone well-versed in community policing, following the program that Potter had established. And, she also wanted a chief that had the respect of the minority community. ${ }^{335}$

Race was absolutely a major consideration in Katz's selection. As Moose wrote, "She also told me, later, that she was determined to try and advance African-American police officers within the department. This wasn't why she chose me, but it was an additional

\footnotetext{
333 Author Unknown, "Moose for Chief," 4.

${ }^{334}$ Rachel Zimmerman, “Guess Who's Coming To Power?” Willamette Week, 7/22-7/28/1993, 16.

${ }^{335}$ Charles Moose and Charles Fleming, Three Weeks In October; The Manhunt For The Serial Sniper, (Waterville, Maine: Thorndike Press, 2004), 379.
} 
reason to choose me. She knew that by promoting me, the department would have better success recruiting more black officers, and she would also be making room in the upper ranks to promote younger black police officers, one of whom might be a future chief." 336

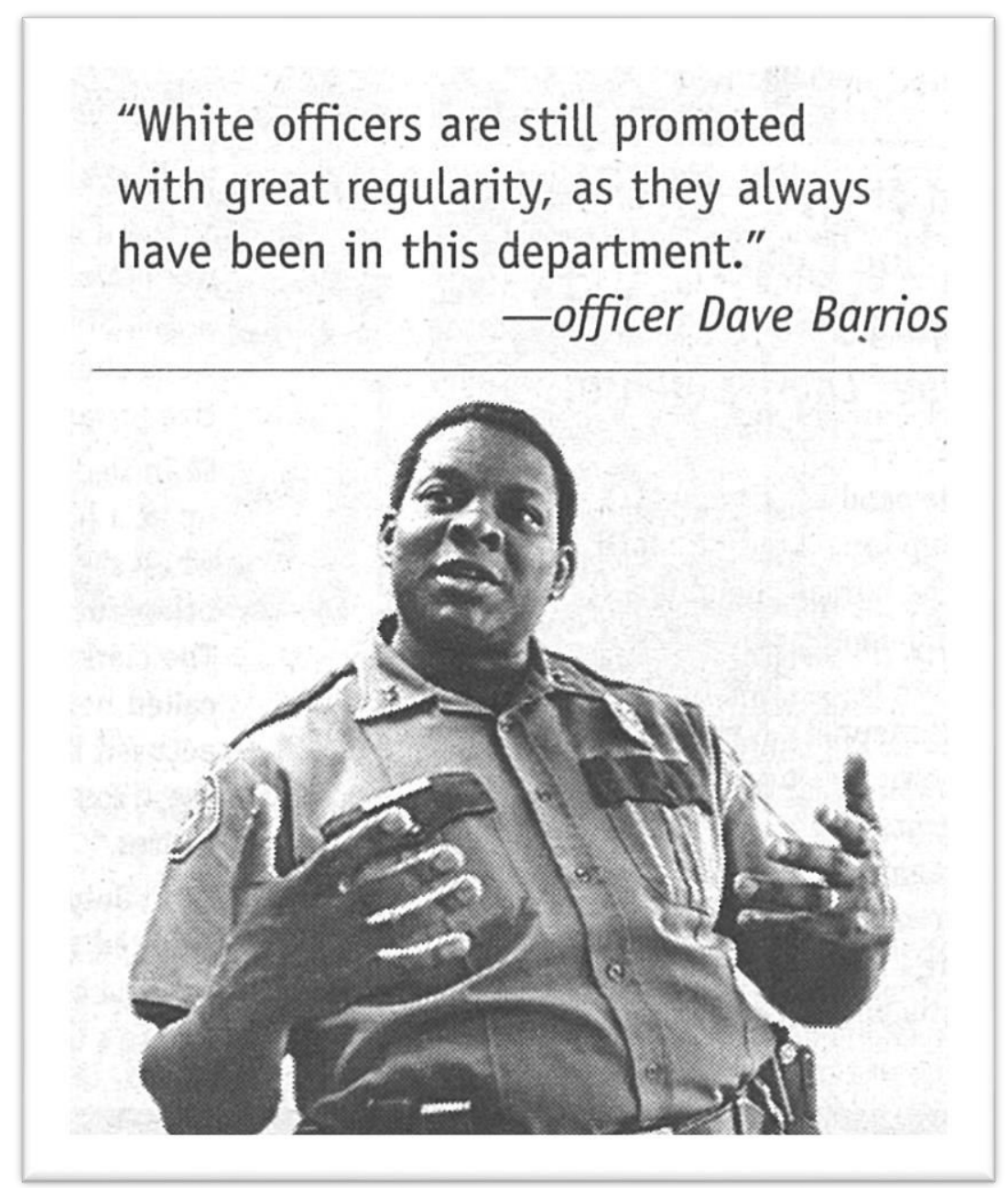

Figure 10 Chief Moose in in 1997. Courtesy of Willamette Week.

\footnotetext{
${ }^{336}$ Moose and Fleming, Three Weeks In October, 379, 380. Derrick Foxworth, a black police officer, was promoted to police chief by Mayor Katz in 2003. https://www.portlandoregon.gov/police/40004 (DOC 10/9/2015)
} 
But there was one other additional reason, besides race, that weighed heavily on Katz's decision, and led her to lean her selection heavily towards Moose as chief. Moose had the public perception of being a major proponent of gay rights in Portland.

Dating back to 1975, the annual Portland's Gay Rights Parade had been a popular cultural event. However, in the early 1990s, contempt against gay and lesbian people was still prevalent in Portland. Interestingly, Moose calls his participation in the gay rights parade "an important part in my advancement within the ranks of the police department." 337 Chief Potter had marched in the gay rights parade the year before as the only uniformed police officer participating. Potter then asked Moose to join him the next year, and Moose did so. The move was seen by many in the Portland Police Bureau, especially the old guard, as an affront to propriety. ${ }^{338}$ Moose stated that he felt at the time that his participation, as a uniformed, North Precinct Captain could have had a negative impact on his career - even though he was marching, uniformed, with the then current Chief of Police, Tom Potter.

Moose claims that years later, Mayor Katz performed something like a "litmus test" to make her final decision for chief of police, between her last two candidates - Charles Moose and Portland Assistant Police Chief Dave Williams. Katz privately asked each of the two if they would feel comfortable marching in the annual gay rights parade, just as Tom Potter had done, while in police uniform. Williams told Katz that due to his

\footnotetext{
${ }^{337}$ Moose and Fleming, Three Weeks In October, 376.

338 Moose and Fleming, Three Weeks In October, 377.
} 
conservative religious convictions he would not be willing to march in the parade in uniform. Moose answered the question quite differently. He noted that he had already been marching in the parade for years, in uniform. Moose explained to the mayor that participating in the parade "didn't have that much to do with gay pride or gay rights, or whether I did or didn't support gay people. To me, it was about showing my support for civil rights for all the citizens of Portland - irrespective of their sexual, racial, religious or economic orientation." ${ }^{339}$ Moose says that this response was the reason Katz selected himself over Williams.

This was not just posturing to help obtain a political appointment. Moose was committed to the parade, and wanted more visible officer involvement. This support continued while he was chief. A June 30, 1994 Portland Police Bureau memo stated that the annual Gay \& Lesbian Pride Parade would be held on Saturday, July 9 in downtown Portland. The memo, written by Chief Moose and read to all roll calls stated, "I will be walking in the parade and I believe my participation and that of any Bureau member who decides to participate, is a worthwhile statement in support of equal rights for all citizens. Sworn members are authorized to wear their uniform." 340

PPB's October 1996 Strategic Plan emphasized "promoting human rights, mutual respect and courtesy," not typical or traditional things one would expect to find in a

\footnotetext{
${ }^{339}$ Moose and Fleming, Three Weeks In October, 382.

${ }^{340}$ City of Portland Archives, B/006879, Chief's Office Files, "Gay Pride Parade/Saturday July 9, 1994, 12:00pm, Memo 6/30/1994."
} 
report written by a police bureau. Mayor Katz said of the new emphasis, "That is a new focus and value that was in past plans, but has risen to the top." ${ }^{341}$ Chief Moose said the emphasis has "made us more efficient, it's made us more responsible to the community." 342

The Willamette Week characterized the Katz/Moose relationship quite succinctly at the time of his appointment to chief when it wrote that "as two new kids on the block they are inexorably linked: One's success will depend on the other's." ${ }^{343}$ Even a year later, Mayor Katz considered the Moose appointment as her greatest achievement to that point. ${ }^{344}$ In April of 1997, even at the height of the Mike Garvey and Foxworth \& Orr cell phone "scandal," Moose was called "the highlight of (Katz's) resume" as mayor. ${ }^{345}$

The night Moose was sworn in as police chief, he drove to Salem, to the Oregon State Penitentiary. He met with an African-American men's group in the prison, Uhuru Sa Sa, and talked with the men about what they would face when they had served their debts to society. ${ }^{346}$ Even an appointment to the highest policing position in Portland had not deterred Moose's commitment to community policing, volunteerism, and service. Moose let it be known by his visit that he was going to serve the black community.

\footnotetext{
${ }^{341}$ Scott Learn, "New Police Priorities Set Out In Strategic Plan Get Approval By Council," The Oregonian, 10/3/1996, E 04.

342 Learn, “New Police Priorities," E 04.

${ }^{343}$ Zimmerman, "Guess Who's Coming To Power?" 16. The "cell phone scandal” involved top administrators of the PPB who used their work phones for personal calls.

344 Jonathan Nicholas, "Seeking a Sense of Community? Take a Walk on the Wide Side," The Oregonian, 6/26/1994, L 03.

345 Steve Duin, “Moose Copies Cat In The Hat," The Oregonian, 4/20/1997, D 01.

${ }^{346}$ Zimmerman, "Guess Who's Coming To Power?" 12.
} 
Just six weeks after his appointment, Chief Moose addressed the think tank of civic responsibility - the City Club of Portland. ${ }^{347}$ As a reporter noted, Moose was "warmly received" by the "liberal, lunchtime crowd." Moose laid out his platform of community activism, and also showed an "idealistic streak." Moose departed from a traditional state of the force address and looked at the standing of the community as a whole. He wanted to talk about his "vision." It was classic "community policing." Moose asked the attendees, "Why do we have so much poverty? Why is there so much homelessness? Why is it we never even ask those kind of questions of each other?"348 It was clear that Moose was going to use his position of chief to bring a different type of service to the community than had been seen from former police chiefs. Policing Portland would have a different perspective under Chief Charles Moose.

One of Moose's stated favorite hobbies was watching televised sports. He used the sports metaphor when describing the bureau at the moment when he assumed top leadership. Moose likened it to a football team, "with specialized players who operate on instructions from the top." 349 But as chief, Moose wanted to transform the staid, established football team into a basketball team. The comparison drew illusions to something more free flowing, more adaptable, more able to respond to unforeseen

\footnotetext{
347 Charles Moose, "The Theory and Practice of Community Policing: An Evaluation of the Iris Court Demonstration Project" (PhD Diss., Portland State University, Doctor of Philosophy in Urban Studies, 1993), 57. Moose defines the City Club in his dissertation as "a group of Portland activists who gather information and study issues that affect the city of Portland."

${ }^{348}$ Barnes C. Ellis, "Moose Exhorts Portlanders To Keep Their City," The Oregonian, 8/7/1993, B 04.

${ }^{349}$ Barnes C. Ellis, "Moose Exhorts Portlanders To Keep Their City," The Oregonian, 8/7/1993, B 04.
} 
circumstances, a team where each member executes the fundamentals of the sport.

They can all dribble. They can all pass. And as Moose was quoted as saying, "everyone needs to be able to shoot." 350

Just a little over two months after taking the job, The Oregonian called Chief Moose "one of the most visible and accessible chiefs Portland has ever known." ${ }^{351}$ This may have been a wise strategy on his part, for the Willamette Week had openly warned Moose about "the tightrope he must walk in order to make it in a town that polishes off police chiefs as quickly as fine chardonnay." ${ }^{\prime 32}$

Moose said of his hands on, visible management style, "you can only do so much of that from the office. At some point you do have to be out on the street." ${ }^{\prime 353}$ This sentiment was not lost on the officers serving under Moose. Detective Sgt. Robert King said of Moose that, "as chief, he was still a working police officer who understood the work of police officers." ${ }^{354}$ But Moose was open to new ideas as well. As C.W. Jensen, police spokesman said in 1994, "One thing Chief Moose doesn't want to hear is, 'We've always done it that way."'355 Sheldon Greenberg, director of the Police Executive Leadership Program at John Hopkins University in Baltimore said of the PPB, "there is a

\footnotetext{
350 Ellis, “Moose Exhorts Portlanders," B 04.

${ }^{351}$ Phil Manzano, "Portland's Police Chief Moose On The Loose," The Oregonian, 9/5/1993, C 01.

352 Zimmerman, "Guess Who's Coming To Power?" 12.

${ }^{353}$ Manzano, "Portland's Police Chief Moose On The Loose," C 01.

${ }^{354}$ Maxine Bernstein "Moose Closes Out 6-Year Tenure of Achievement, Pitfalls as Chief," The Oregonian, 7/28/1999, A 01.

${ }^{355}$ Phil Manzano, "Moose Revamps Command Staff," The Oregonian, 6/21/1994, B 03.
} 
willingness to innovate and experiment, to try new things, which is not common in policing."356

Moose wrote in a June 1994 memo, "We need to constantly seek ways to flatten the organization chart and encourage the empowerment of the many talented individuals within the Police Bureau." 357 Moose definitely needed to empower his force, for many of its officers were new to the job. One fifth of the 900 Portland police officers were rookies, due to the rush of retirements at the end of the Potter era. ${ }^{358}$

Moose had the desire to make the Portland Police Bureau do more, to try new avenues of enforcement and find new ways to serve the community. At the City Club of Portland address on August of 1993, Moose said, "One of the real goals of the police bureau... is that we continue to push the limits." ${ }^{359}$

Fifteen months after Moose was selected police chief, the press wrote that his "trademark has been his close ties with rank and file officers, active community involvement and dedication to community policing principles." 360 Moose was highly regarded in preserving that association with the rank and file. As an illustration, consider that it would have been completely acceptable for Moose to abandon the blue officer's uniform and begin to wear a business suit and tie. He refused to do so. Moose wanted

\footnotetext{
356 Maureen O'Hagen, “Hope or Hype,” Willamette Week, 9/27-10/3/1995, 19.

357 Manzano, "Moose Revamps Command Staff," B 03.

358 Rollins and Long, "Moose's Dedication Wins Katz," A 01.

${ }^{359}$ City Club of Portland, "New Directions For Portland's Police Department." 8/6/1993. https://www.youtube.com/watch?v=eP1UXxiVBqo\&feature=youtu.be

360 Phil Manzano, "Moose Finalist to Head Project," The Oregonian, 9/11/1994, A 01.
} 
the association of a police officer to be apparent in his police chief role. "Sure, I'm the chief, but I'm still a police officer," he said in November of 1994. "I'm a police officer. And the day I forget that, is the day I should get out of the business." ${ }^{362}$ Greg Pluchos, president of the Portland Police Association in 1999 said, "Chief Moose has always been a cops' cop. He's never lost sight of that as chief, and I think that's been demonstrated by his eagerness to wear his uniform daily. I think he has a real affinity and love for Portland." 363

Chief Moose would walk the beat in Old Town, ride shotgun with underling officers, or assist with directing traffic in a Northeast Portland intersection with crashed vehicles. ${ }^{364}$ In March of 1994 , driving by a dispute on Northeast $15^{\text {th }}$ and Alberta, off duty Moose saw a group of individuals in an argument. He pulled over and radioed for officers to respond to the disturbance. As he did so, one member of the group, Daniel Gill, displayed a firearm, and after shooting one of the assemblage, Tommy Felix, turned and ran. Moose assisted the responding officers of the Gang Enforcement Team in locating Mr. Gill. ${ }^{365}$

Another example of this leadership from the top down style was that when Moose made it mandatory for all officers to wear a bulletproof vest, he donned one himself. He

\footnotetext{
362 Tom Hallman, "Rookies To Chief, Safety Comes First," The Oregonian, 11/14/1994, B 04.

363 Maxine Bernstein, "Police Chief Resigns," The Oregonian, 5/27/1999, A 01.

364 Manzano, "Portland's Police Chief Moose On The Loose," C 01.

365 City of Portland Archives, B/030226, 24-02-15, Subject Files, Police: Mayor's Office, 1993-1996, Police Related Press Releases/Video Tapes, file "Jan-March 1994 News Release" "Chief Moose, Officers Capture Suspect In Gang Related Shooting," 3/25/1994.
} 
had ample reasons not to do so: he had to attend routine meetings and greet community leaders and civic officials and the like. A four pound Kevlar vest is terribly uncomfortable for someone often found at a desk. But Moose would not have it any other way. "I'm not going to ask my officers to do something I'm not going to do. If they have to wear a vest, then I have to wear a vest. Anything else would be hypocritical."366

Moose wanted the higher echelon of the bureau to maintain something akin to a connection to the patrol officers. He didn't want their focus on policy and administration to distract them from the real world of cops and robbers, drug dealers and prostitutes. He wanted to make sure that the command staff did not lose sight of the task at hand, the mission of the bureau on the proverbial street and the nitty gritty details of policing. Under the title of "Operation All Out and About," precinct commanders and lieutenants were required to begin serving eight hours per month "in a uniform patrol function." 367

The goals of the program were multileveled. The first was to have more uniformed officers visible on the street. In addition, the program was also intended to "expose our command staff personnel to the ever-changing job of uniform patrol." 368 The experience was also designed to help enlighten the ranking officers in their development of any

\footnotetext{
366 Tom Hallman, "Rookies To Chief, Safety Comes First," The Oregonian, 11/14/1994, PB 04.

${ }^{367}$ City of Portland Archives, B/030229, 24-03-36, Subject Files, Police: Mayor's Office, 1993-1998, Box 2, file "The Bulletin," “Chief's Corner," The Bulletin, 2/27/1997.

${ }^{368}$ City of Portland Archives, B/030229, 24-03-36, Subject Files, Police: Mayor's Office, 1993-1998, Box 2, file "The Bulletin," "Chief's Corner," The Bulletin, 2/27/1997.
} 
bureaucracy's life blood - policies and procedures, and to also help better inform selections involving equipment and technology.

In explaining the program, Moose noted that some street officers might benefit from knowing that the command staff would be on the street to help "refresh" their "knowledge of policing in today's urban environment." Perhaps expecting some pushback, the chief observed that "it is easy to say that we do not know anything about your job, but I think you will be surprised. We have all done the job because the Portland Police Bureau does not hire or promote command staff from the outside." ${ }^{\prime 369}$

In 1997, using his regular column in the PPB's internal newsletter, The Bulletin, Chief Moose tackled the topic of a Portland police officer's memorial. The conclusion of the piece provides an insight into Moose's thoughts on civic duty, leadership, and community policing. Moose wrote,

As we all know, being a police officer in our democratic society is very difficult. The challenges grow every day. Our jobs can be dangerous, frustrating, even tedious, but law enforcement is a tremendously rewarding career. In today's society, police officers can significantly improve the quality of life for the citizens of their community by keeping the peace and solving problems despite sometimes overwhelming odds. It is important that we give each other the appropriate recognition, support and respect at all times. There is much more

${ }^{369}$ City of Portland Archives, "Chief's Corner," 2/27/1997. 
we can do for those who give the ultimate for our agency, but we can only reach this higher level if we first learn to discuss and recognize our weaknesses. This will be an ongoing effort and it will take all of us. ${ }^{370}$

This was classic Moose. In his address to his officers, he was not only outlining his concept of police officers in the community as problem solvers and as agents of the community good who were improving the lives of the citizens; Moose was also calling for more openness and transparency in the bureau - a trait he would personally exhibit to the press and public in Portland when he shared embarrassing incidents from his personnel files.

Despite his efforts to be transparent, Moose was not universally admired early on in his administration. For one, he took a lot of flak from the public for his public speaking style. Moose had very distinct diction (one that this researcher has found enjoyable to listen to), but one that some in the press disparaged. Moose recalled that journalists and editorialists criticized his manner of speaking and were "usually not... very nice about it." Moose said "they didn't like my accent, or my inflection, or my choice of words. They didn't like the sound of the North Carolina way I speak - or whatever it is that makes me sound the way I sound - and several of them made fun of it. I didn't

${ }^{370}$ City of Portland Archives, B/030229, 24-03-36, Subject Files, Police: Mayor's Office, 1993-1998, Box 2, file "The Bulletin," "Chief's Corner," The Bulletin, 6/5/1997. 
know what to do about that except ignore it. I don't sound like a white guy, because I am not a white guy. Why should I try to sound different?"371

"a time bomb. He's going to lose his temper the first time Vera makes a decision he doesn't like."372

Former Portland Police Chief Penny Harrington, 1993.

In selecting Moose as her chief of police, Mayor Katz had to deal with some rather disturbing accounts in his personnel file. These accounts would follow Moose throughout his tenure as the chief of police, and indeed throughout his entire law enforcement career.

Charles Moose had legendary anger issues, and an incredibly short fuse to boot. His quick temper made some in the community wonder how he could possess such a negative character trait and still be an effective manager. In April of 1997 The Oregonian was pondering this very notion: “Given Moose's public displays of anger at some community meetings, many people say he has a dark side. They wonder whether his decisions might be rash." ${ }^{373}$ And it was not just the community - this reputation of an angry chief was entrenched within Moose's bureau as well. “Officers have been fed up with the chief's bad temper and bullying tactics for years," reported an article from January of that same year. ${ }^{374}$ In 1997, the Willamette Week wrote, "Anyone who has

\footnotetext{
371 Moose and Fleming, Three Weeks In October, 352.

372 Zimmerman, "Guess Who's Coming To Power?" 12.14.

373 David Anderson, "Police Chief Faces The Heat," The Oregonian, 4/20/1997, D 01.

${ }^{374}$ Maureen O’Hagan, “Phone Tag,” The Willamette Week, 4/30/1997, 14.
} 
spent time with Charles Moose has probably seen his low boiling point. Within the bureau, stories about the chief's blow-ups are legion." ${ }^{375}$ City Commissioner Charlie Hales described Moose as possessing "a protruding temper."376

In April of 1997, Stephen A. Houze, an attorney for PPB Captain Mike Garvey, requested Moose's personnel files as part of Garvey's lawsuit against the City. Garvey insisted he was disciplined because he was gay, and had filed a discrimination lawsuit. With the possibility of the files going public, Moose held a news conference and preemptively released sections of his personnel files to the press. ${ }^{377}$

Moose's files contained four discipline action reports, from 1982, 1987, 1988, and 1992. In each situation, Moose felt he was discriminated against because he was black. Each time, he was disciplined for "violating the bureau's standards of conduct, communication and procedure," and sent to counseling. ${ }^{378}$ In all four cases, Moose was accused of "blowing up" at city employees or store clerks. All four of the victims of Moose's wrath were women. ${ }^{379}$ When the reports were released, Moose said "I'm

\footnotetext{
${ }^{375}$ Maureen O'Hagen, “Internal Affairs,” Willamette Week, 1/15/1997, 21.

376 O'Hagen, “Internal Affairs," 21.

${ }^{377}$ During the Summer and Fall of 2015, the author spent a considerable amount of time attempting to gain copies of the specific reports issued to the press. Numerous requests were sent to the Portland Police Bureau's Records Division. While several reports were obtained concerning other areas of this paper, the records pertaining to Moose's outbursts were not released. Attempts were made again to gain these reports specifically, and the researcher was instructed to contact the City of Portland's Bureau of Human Resources. Numerous emails to that office regarding these specific files (again, already released to the press nearly 20 years ago) were not answered.

378 David Anderson \& Laura Trujillo, "Moose Opens Book On Four Disciplinary Incidents In His File," The Oregonian, 4/26/1997, 01.

379 O'Hagan, "Phone Tag," 14.
} 
ashamed of my behavior in these situations. I'm clearly embarrassed that I have to relive those situations. I don't want to behave that way." 380

The reports offer several unique opportunities to examine some aspects of Moose's character. First, these documents involve the rumored "anger issues" hinted at during Moose's selection process for chief, and they provide some insight into the theory that his opponents used to charge that Charles Moose was an angry man who had anger management issues. Second, the reports give us a chance to see what Moose dealt with, day in and day out, as a black man in Portland and an opportunity to see how he dealt with race and racial issues. As he stated in April 1997, "I think it's an ongoing problem for me because I continue to be a black person in a predominantly white community." ${ }^{381}$ A reporter covering the release of the reports wrote that Moose "suggested" that these incidents would not have happened if he were white. ${ }^{382}$ Moose also criticized the bureau for the way it interpreted these incidents. "They never considered that I was a victim in those situations," he asserted, "I know the feeling that you don't feel supported." $383 \mathrm{He}$ also said, "I see it differently than the police bureau saw it, but I'm willing to live with [that]." ${ }^{384} \mathrm{He}$ explained that "The police bureau has never sided with

\footnotetext{
380 Anderson and Trujillo, "Moose Opens Book," 01.

${ }^{381}$ Anderson and Trujillo, "Moose Opens Book," 01.

${ }^{382}$ Anderson and Trujillo, "Moose Opens Book," 01.

${ }^{383}$ Anderson and Trujillo, "Moose Opens Book," 01.

${ }^{384}$ O’Hagan, "Phone Tag," 14.
} 
me, never agreed that perhaps I am a victim in this matter, so I've taken the punishment given me by the police bureau." 385

The incidents were as follows:

In December, 1982, at the downtown Nordstrom department store, Moose was shopping for shoes with his son. Moose was not getting the service he felt he deserved from the clerk, and was reported to have asked the clerk (rhetorically) "Does my skin have to turn white to get help?" 386 He was also heard to have said "You all stick together you whites... You honkies." It was also reported that he used foul language, calling her a "fucking bitch." 387 Moose claimed that he did not use the term "honkies" or foul language. ${ }^{388}$

Moose had an interesting perspective on all the media attention. Reflecting on the incident in his book, he wrote, "One newspaper reported that l'd called the people in Nordstrom "honkies." The TV stations replayed that story and showed the article on camera, but with the word "honkies" blacked out. They said I used a "racial slur." Which somehow sounded worse than saying "honkies." You don't usually hear about black people using "racial slurs" when talking about white people, but there it was." 389

\footnotetext{
385 “Moose Releases Personnel Records in Advance of Suit," The Portland Skanner, 4/30/1997, 3.

386 "Moose Releases Personnel Records," 3.

${ }^{387}$ Maureen O'Hagen, “Black and White," Willamette Week, 5/7/1997, 13.

388 Anderson and Trujillo, "Moose Opens Book," 01.

${ }^{389}$ Moose and Fleming, Three Weeks In October, 364.
} 
In July, 1987 Moose applied for a car loan at the City of Portland Employees Credit Union. The loan officer was working on his application when another police officer came in that she had worked with earlier. She passed on Moose's paperwork to another employee so she could assist the longtime customer. A short time later, she heard Moose "making a fuss," so she apologized to him. The loan officer said that Moose then became angry, used foul language, and then pointed his finger at her and told her "never to... wait on him again." 390 Moose denied using the foul language and said that he thought that he told the loan officer that she would rather wait on her white friends. ${ }^{391}$

In March of 1988 Moose found himself in hot water again, this time when the North Precinct Neighborhood Against Crime Coordinator made a comment about the acidwashed jeans Moose was wearing, saying that they were the same style of jeans a recent crime suspect was wearing. Several officers witnessed the event and heard Moose again use foul language as he yelled "at the top of his lungs." 392 Some said he told her to "fuck off." 393 The suspect referred to was black, and Moose felt that the jeans comment was racially-based. He described it as "a racist remark, delivered in a racist manner" and said that the neighborhood coordinator would have "never, ever said (it) to a white police officer."394

\footnotetext{
390 Anderson and Trujillo, "Moose Opens Book," 01.

391 Anderson and Trujillo, "Moose Opens Book," 01.

392 Anderson and Trujillo, "Moose Opens Book," 01.

393 Zimmerman, "Guess Who's Coming To Power?" 14.

${ }^{394}$ Moose and Fleming, Three Weeks In October, 360.
} 
In his autobiography, Moose says that the woman was "very dismissive," and spoke in a derogatory tone when she said he looked like a "gang banger." In this account, Moose claims that he said, "I am not a fucking gang member, and you know it. You're wrong to call me that." 395 When revisiting the issue, Moose says that he does not deny that it happened, but provides a different interpretation on the matter. "It wasn't like I said "fuck you" to her, or told her to "fuck off." I just used a rather aggressive adjective."396

A complaint in May of 1992 was the last negative report, about a year before Moose was elevated to chief. As he was entering a downtown office building, in his PPB uniform, a security guard greeted him with the standard greeting, "Good morning sir; can I help you?" Moose turned to her, and with a look of anger on his face said, "Well, if an officer in uniform has to be questioned, then forget it." 397 Moose left, and the guard followed him outside. She said that when she caught up to him, Moose said, "I'm sick and tired of you white people asking questions of black people." ${ }^{398}$ She tried to shake Moose's hand as he was getting into his car, and he reportedly hit her with the car door. Moose claimed that this was an accident. In an Internal Affairs investigation of the incident, Moose said "It's almost like they get some instructions that when they see a black person they need to run their antennas up and challenge this person and confront this person. There's no free movement." ${ }^{399}$

\footnotetext{
395 Moose and Fleming, Three Weeks In October, 358.

${ }^{396}$ Moose and Fleming, Three Weeks In October, 359, 360.

397 Anderson and Trujillo, "Moose Opens Book," 01.

398 Anderson and Trujillo, "Moose Opens Book," 01.

399 O’Hagen, "Black and White," 13.
} 
As part of his reprimand, Moose was sent to see a psychologist, who happened to be the only black psychologist in Portland. The counselor had some discouraging words for Moose. According to Moose, he said, "You live in America, and you work for the police department. The police department is a racist organization. Every police department in America is a racist organization. You can't be surprised if you get exposed to racist behavior. You can't get angry. You either have to contain yourself when this happens, or you have to get out." 400

It is interesting to try to speculate as to Moose's thoughts regarding his release of his personnel records to the press. What were his motivations? His political considerations? Surely he must have reflected upon what the response of citizens would be. He certainly did not need to do it. In fact, in line with PPB policies, Moose could have had the earlier incidents expunged from his personnel files. ${ }^{401}$ In 1993 Moose chose to have the incidents left in his file "because I need to remind myself that that was very stupid." 402

\footnotetext{
400 Moose and Fleming, Three Weeks In October, 361, 362. Moose says that this visit to the psychologist was the only activity that would resemble "anger management classes," and that press reports that he attended several sessions of anger management classes is incorrect. "It's a lie, and it's wrong, and it's easy to prove that it's wrong, but I've stopped trying. This has become the fact. It will be in my obituary. Despite the fact that it's a lie and it's wrong." (366). This researcher made numerous attempts to access these previously publicly released files to verify this discrepancy, both through the Portland Police Bureau Records Department and the City of Portland's Human Resources Department. These requests were denied or straight up ignored.

${ }^{401}$ As the Willamette Week explained, PPB procedure allowed that "disciplinary action that falls short of demotion or dismissal can be purged from an officer's file after five years if there are no repeat offenses." Zimmerman, "Guess Who's Coming To Power?" 14.

402 Zimmerman, "Guess Who's Coming To Power?" 14.
} 
He reiterated that sentiment in 1997 when he said, "I need to be reminded of my performance because I don't want to perform that way again." 403

Members of his bureau viewed Moose's actions within the context of his race. When Moose released these reports in 1997, some officers felt that they reinforced the view that Moose was "overly sensitive to alleged discrimination while showing his own bias by promoting minority officers." 404 This would not be the only instance of his ethnicity being conflated into his management of the force. As chief, Moose was blamed by many for holding black cops to a higher standard. He unabashedly addressed these concerns when he said, "we all hold ourselves to a higher standard. We have to." 405

Needless to say, these allegations caused quite a frenzy in the Portland public. As one might expect, community responses to these outbursts flooded the mayor's office. Some in the community took the time to write to Mayor Katz supporting Moose. Ms. Savilla Tabor of North Portland thanked Mayor Katz for standing up for Moose when these accusations were made against him. Ms. Tabor stated that she had "worked as a police volunteer at Iris Court and know of his work at Columbia Villa some years ago. I found him a person of fine qualities. I know of the long hours, even at risk for his life, to rid the city of drugs, crime and violence with no thought of praise." 407

\footnotetext{
403 O'Hagen, "Black and White," 13.

404 O'Hagen, "Black and White," 13.

405 Zimmerman, "Guess Who's Coming To Power?” 14.

407 City of Portland Archives, B/030042, 40-12-40, Subject Files, Mayor Katz, Sam Adams Police-Public Correspondence, Executive Orders, Campaigns, 1997-1998. Letter from Savilla Tabor to Mayor Vera Katz, 4/28/1997.
} 
Maxine Selling of Southwest Portland expressed her appreciation to Mayor Katz in July of 1997 for her "superb judgement in appointing Charles Moose police chief, for standing with him at the public occasions when he's been placed in a difficult situation and the Oregonian has made capital of it." ${ }^{408}$ Selling concluded her note by thanking Mayor Katz for serving and for supporting Moose, who she thought was "an unusual man, even spiritual man remarkably well able to speak and relate to 'everyman.'"409

Not all of the letters to the mayor were complimentary of the chief. Ken Betterton of Salem wrote that "you should fire Charles Moose for his racist comments about "honkies." The comment is terribly offensive to millions of whites in this country. If a white police chief had called blacks "niggers," the chief would have been out the door. Vera, why the double standard?" 410 David Lamarcha of North Portland wrote: "We're shocked by the Mayor appointing a Chief of Police that was known for referring to WHITE people as F.N. "Honkys." If we had a white Chief of Police call anyone Nigger all hell would break loose as the case in L.A. Calif." ${ }^{411}$

\footnotetext{
408 City of Portland Archives, B/030042, 40-12-40, Subject Files, Mayor Katz, Sam Adams Police-Public Correspondence, Executive Orders, Campaigns, 1997-1998. Letter from Mayor Vera Katz to Savilla Tabor, 5/20/1997.

${ }^{409}$ City of Portland Archives, Letter from Mrs. Maxine Selling to Mayor Vera Katz, 7/15/1997.

${ }^{410}$ City of Portland Archives, B/030042, 40-12-40, Subject Files, Mayor Katz, Sam Adams Police-Public Correspondence, Executive Orders, Campaigns, 1997-1998. Letter from Ken Betterton to Mayor Vera Katz, 5/20/1997.

411 City of Portland Archives, B/030042, 40-12-40, Subject Files, Mayor Katz, Sam Adams Police-Public Correspondence, Executive Orders, Campaigns, 1997-1998. Letter from David LaMarcha to Mayor Vera Katz, 4/30/1997 (received date -letter not dated.). LaMarcha must have been referring to the Rodney King incident.
} 
Luciana Barberis of Southwest Portland expressed "anger and concern over the racist and divisive remarks and the pattern of abusive behavior" that was documented in the personnel files. But Barberis was even more disturbed that Mayor Katz had the information and still appointed Moose as chief. ${ }^{412}$ Barberis asked that Moose be removed from the position and be replaced with a chief who "shows the high standards that we have come to expect from the Portland Police Bureau." 413

In addition to Moose's perceived racism in these incidents, the gender of the recipients of his rage was not overlooked by constituents. Southeast Portland resident David Gray said that a white chief would be asked to resign in disgrace for the "ugly" racist and sexist incidents. While Gray signed his letter "sarcastically yours," his missive still provides an interesting historical time stamp on racial sentiment in Portland at the time. Gray asked Mayor Katz to "imagine the explosive uproar if a white police chief had perpetrated similar racist and sexist incidents. A white male police chief would probably be attacked and condemned as a racist and sexist hate monger by the local far-left liberal news media.... He'd probably even be asked to whimper his apologies before he was sent off to the woods of Northern Idaho. But Portland Police Chief Charles Moose need not worry-he's not a white male!"414

\footnotetext{
412 City of Portland Archives, B/030042, 40-12-40, Subject Files, Mayor Katz, Sam Adams Police-Public Correspondence, Executive Orders, Campaigns, 1997-1998. Letter from Luciana Barberis to Mayor Vera Katz, 4/28/1997.

${ }^{413}$ City of Portland Archives, Letter from Luciana Barberis to Mayor Vera Katz, 4/28/1997.

${ }^{414}$ City of Portland Archives, B/030226, 24-02-15, Subject Files, Police: Mayor's Office, 1993-1996, Police Related Press Releases/Video Tapes, file "Police - No Response Letters," Letter from David Gray to Mayor Katz, 4/23/1997.
} 
The media attention even garnered some out of state responses. F.G. Williams of Independence, California took the time to write Mayor Katz. Williams noted that the mayor had "chosen to stand by him (Moose) in spite of the many racial slurs he has uttered - not to mention his use of the "F" word." Williams then posed two questions to the mayor of Portland, "would you be standing behind the Chief if he were white?" and "Would you be standing behind him had he used the word "KIKE" ?"415 Williams ended by giving Mayor Katz a thought to consider. Williams wrote, “As I see it, Charles Moose should be tossed out on his ear. I am sure that Bullwinkle Moose could do a much better job!" 416

An anonymous letter writer was aghast. "That you knew about Chief Charles Moose's record of blatant, obscene, public racism and still appointed him to the office he now holds is beyond my comprehension... This has given a chilling new meaning to the word insensitive." 417 The correspondent also called out the sexism of Moose's comments. The author of the letter called for both Moose and Katz to resign.

The mayor responded to many of these messages with a form letter, tweaked a bit for some of the individual recipients. The mayor wrote that, "Obviously, I did not make the decision to appoint the chief in a vacuum. I was fully aware of the four complaints filed

\footnotetext{
415 City of Portland Archives, B/030042, 40-12-40, Subject Files, Mayor Katz, Sam Adams Police-Public Correspondence, Executive Orders, Campaigns, 1997-1998. Letter from FG Williams to Mayor Vera Katz, 4/29/1997.

${ }^{416}$ City of Portland Archives, Letter from FG Williams to Mayor Vera Katz, 4/29/1997.

${ }^{417}$ City of Portland Archives, B/030042, 40-12-40, Subject Files, Mayor Katz, Sam Adams Police-Public Correspondence, Executive Orders, Campaigns, 1997-1998. Letter from Anonymous to Mayor Vera Katz, 4/28/1997.
} 
against the chief over the course of his career." ${ }^{\prime 18}$ The mayor then reiterated that Moose's files also contained "glowing performance reviews, numerous commendations from an illustrious group of national, state and local leaders, and a wide array of praise from citizens." Next, she made clear the chief's accomplishments, the primary being that the Portland community had seen an $11 \%$ reduction in crime in 1996 - the lowest crime rate since $1970 .{ }^{419}$

In private conversations held between the mayor and the chief about his anger issues, Moose claims that Katz "understood" why he was driven to lash out. Her perspective as a woman, and a Jew, helped her empathize with the chief: "She told me she understood that, as a black man and a black police officer in a town like Portland, I experienced this kind of disrespect on a daily basis." 420

While these four incidents were the most publicized, they were by no means Moose's only documented cases of anger control issues. The former PPB budget director, Nancy Dunford, submitted a "whistle blower" complaint with the Oregon Bureau of Labor and Industries, alleging that the Bureau had demoted her because she pointed out “improper financial practices." ${ }^{421}$ But she also claimed that at a January 30, 1997 meeting addressing these irregularities, Chief Moose "blew up at her." "During the

\footnotetext{
418 City of Portland Archives, B/030042, 40-12-40, Subject Files, Mayor Katz, Sam Adams Police-Public Correspondence, Executive Orders, Campaigns, 1997-1998. Letter from Mayor Vera Katz to Savilla Tabor, 5/20/1997.

${ }^{419}$ City of Portland Archives, Letter from Mayor Vera Katz to Savilla Tabor, 5/20/1997.

${ }^{420}$ Moose and Fleming, Three Weeks In October, 381.

${ }^{421}$ David R. Anderson, “Financial Practices Of Police Draw Fire," The Oregonian, 5/9/1997, C 11.
} 
meeting, Chief Moose yelled at and otherwise abused me verbally to the point where I felt unsafe," Dunford alleged. Mayor Katz said she was aware of the situation and that Moose was "reading books to help him deal with his anger." ${ }^{422}$ Charles Makinney, who ran the PPB fiscal and records division from 1981 to 1994 said in July of 1999, that "His (Moose's) ability to deal as a manager was horrendous." ${ }^{423}$

While these personal anger management issues were occasionally popping up during Moose's career as a police officer and tenure as chief, one constant professional challenge that followed him during his service was the threat of gang violence in the City of Portland.

In late 1992, the PPB estimated that there were 2,000 Portlanders with a gang affiliation. Johnny A. Gage, who worked with "gang kids" as a houseparent at the House of Umoja, thought the number was closer to $1,000 .{ }^{424}$ Whatever the specific number, the threat of gang violence was ever-present. PPB gang officers were working twelve hour shifts. An elite eight-officer unit addressed "chronic problem areas in neighborhoods where Crips and Bloods loiter." 425 Northeast Portland community leaders asked Oregon Governor Barbara Roberts to dispatch the National Guard to assist the Portland police. Neighbors felt that they lived in "war zones," and the gang situation was called a "growing epidemic." ${ }^{426}$ In September of 1992, there were at least ten

\footnotetext{
422 Anderson, "Financial Practices Of Police Draw Fire," C 11.

${ }^{423}$ Bernstein "Moose Closes Out 6-Year Tenure," A 01.

424 Michael Rollins, "Scrounging To Heal Wounds," The Oregonian, 9/27/1992, A 01.

425 Rollins, "Scrounging To Heal Wounds," A 01.

${ }^{426}$ Rollins, "Scrounging To Heal Wounds," A 01.
} 
reports of shootings between Killingsworth and Alberta from 14th to 18 th avenues. ${ }^{427}$

On September 21st, 1992, there were three shootings in the area that found one gang member dead and four wounded. ${ }^{428}$

On August 7th, 1993, Torrey Carter, a Blood gang member of some renown, was shot and killed. Carter, who went by the street name Notoriouz, or No Toz, was the latest victim in "a string of bloody mayhem" in Portland, which had included the deaths of a Bible school worker, a video store owner, and a Head Start office worker. ${ }^{429}$ Carter, just the latest victim, was found bleeding to death from a gunshot wound to the chest in front of a duplex in the 5200 block of NE Cleveland Avenue. ${ }^{430}$ When he was a high school athlete, Carter was Jefferson's High School's most valuable player in basketball, baseball, and football all in the same year. ${ }^{431}$ Carter died soon after he had been rushed to Emanuel Hospital and Health Center. ${ }^{432}$

Police were terrified that a gang war would erupt on the streets of Northeast Portland in response to the murder of No Toz. In the afternoon of August 7, roughly fifty gang members flocked to the intersection of NE 13th and Emerson Street. About five police cars, including one conveying Chief Moose, arrived at the scene. Attempting to relieve

\footnotetext{
${ }^{427}$ Rollins, "Scrounging To Heal Wounds," A 01.

428 Rollins, "Scrounging To Heal Wounds," A 01.

429 James Mayer, "Shootings Leave 1 Dead, 1 Hospitalized," The Oregonian, 8/8/1993, Pg. C 07 and Michael Rollins \& Elizabeth Wellington, "Red-Clad Mourners Grieve Gang Leader's Death," The Oregonian, 8/17/1993, A 08.

430 Rollins and Wellington, "Red-Clad Mourners Grieve Gang Leader's Death," A 08.

${ }^{431}$ Rollins and Wellington, "Red-Clad Mourners Grieve Gang Leader's Death," A 08.

432 Rollins and Wellington, "Red-Clad Mourners Grieve Gang Leader's Death," A 08.
} 
the tension and anxiety, officers went into the crowd and began discussing the incident with the Blood leaders. ${ }^{433}$ It was a unique response to an extremely volatile situation.

Police were on high alert, and during traffic stops they confiscated six handguns on Saturday night alone. ${ }^{434}$ One week later, after the felled gangster's funeral, 100 Blood members, Carter's family, and friends of the gang gathered for a memorial at Woodlawn Park. Police officers, members of the Gang Enforcement Team, and community outreach workers, descended into the gathering. The public servants again sought out the Blood's leaders and tried to calm everyone down. Moose himself was at the function for about five hours. ${ }^{435}$ As darkness descended upon the scene, community workers gathered money from their pockets and wallets and a quick dinner was assembled. The two groups played basketball. ${ }^{436}$

It was an extraordinary day. “It certainly was something that I don't think any of us will forget," said Sgt. Derrick Foxworth, PPB Spokesman. ${ }^{437}$ Chief Moose recognized the gravitas of the moment, and was quoted as saying "We have a great deal to learn about the causes and prevention of America's violent youth gangs. But I do know that the reaction of the officers... was correct. This job requires compassion. We are helpers and

\footnotetext{
433 Manzano, "Portland's Police Chief Moose On The Loose," C 01.

434 Sara Rubenstein, "Police Increase Patrols After Youth Killed, Another Wounded," The Oregonian, 8/9/1993, B 06. "The weapons included a .38-caliber revolver and three semiautomatic pistols: a $10 \mathrm{~mm}$ Glock, a .380-caliber and a $9 \mathrm{~mm} . "$

435 Manzano, "Portland's Police Chief Moose On The Loose," C 01.

436 Manzano, "Portland's Police Chief Moose On The Loose," C 01.

${ }^{437}$ Rollins and Wellington, "Red-Clad Mourners Grieve Gang Leader's Death," A 08.
} 
the officers offered what limited help they could provide." ${ }^{\prime 38}$ This was the front line of community policing under Moose's administration.

Moose's program raised some questions. Was the success of community policing tied to the race of others? In other words, does a society need a diverse police force to effectively institute and sustain community policing? As Oregonian reporter Michael Rollins noticed, "despite the current political dramas (between the community and the PPB), city commissioners and neighborhood leaders remain convinced that the cultural changes can be made within the bureau to implement community policing." ${ }^{439}$ Was community policing only an ethos for black communities?

Phil Manzano, who wrote in The Oregonian about the gang members and police officers playing basketball after Carter's funeral, contrasted that reaction with the rigid and militaristic police response to sixty-five anarchists on July 18, 1993. A national group of anarchists gathered in Portland, which was billed by supporters as an "UnConference" or the "Holiday in Beirut." ${ }^{440}$ In conjunction with the programming, a nineband punk rock concert was held at the X-Ray Café on 214 W. Burnside Street. The anarchists heard that a group of Nazi skinheads were gathering at Pioneer Square, so about thirty of them marched to the square. ${ }^{441}$ Finding the square absent of Nazis, they

\footnotetext{
438 Manzano, "Portland's Police Chief Moose On The Loose," C 01.

439 Rollins, “New Era of Community Policing Looms For Portland Force," C 12.

440 Holly Danks, "An Inevitable Clash of Ideologies," The Oregonian, 7/20/1993, A 01. Legend has it that the George H. Bush administration used to refer to Portland, Oregon as "Little Beirut," due to the number of protests, and their intensity, that would greet members of his administration when they came to the city.

${ }^{441}$ Ashbel S. Green, "Police, Youths Clash Downtown," The Oregonian, 7/19/1993, A 01.
} 
hiked back to the X-Ray Café, with three Portland police squad cars following along.

Eventually, west Burnside was closed with forty riot gear wearing officers being deployed against sixty-five anarchists, who were adorned with hooded sweatshirts and scarves over their faces. Spilling from the X-Ray Café and onto Burnside Street, they were armed with rocks and knives. ${ }^{442}$ As the standoff gained intensity, suddenly the anarchists scattered.

The anarchists broke into the streets of downtown Portland, with the police following along. Trying to cordon them off, the PPB finally closed in on the anarchists at Third and Washington. Then, suddenly, the anarchists dispersed again. According to reports, the anarchist group "went on a rampage through downtown Portland," clashed with the geared-up riot police, and caused quite a ruckus. ${ }^{443}$ The New Market Theater, McCormick and Schmick's restaurant, and the Portland Outdoor Store were all recipients of the anarchists' rocks and rage, and broken windows were common. ${ }^{444}$ Several parked cars faced the anarchist wrath.

Thirty-one anarchists were arrested for multiple charges, "including rioting, disorderly conduct, vandalism and disobeying a police officer." ${ }^{\prime 45}$ Some blamed the visible display of force by the bureau for inciting the anarchists. Ben Ellis, co-owner of the X-Ray Café

\footnotetext{
442 Green, "Police, Youths Clash Downtown," A 01.

${ }^{443}$ Manzano, "Portland's Police Chief Moose On The Loose," C 01.

${ }^{444}$ Green, "Police, Youths Clash Downtown," A 01.

${ }^{445}$ Brian T. Meehan, "New Anarchists Not Bomb-Throwers, Associates Say," The Oregonian, 7/20/1993, A 11.
} 
said, "I think the police made an absurd move in bringing riot cops down." 446 Twentythree business owners in the Skidmore district authored a letter to the bureau, stating that if the police had been "following true community-policing principles, police should have explained better why officers in full riot gear blockaded the X-Ray Café after youths assembled outside the club." 447 The business owners wondered, "if we truly are members of the community, why was there no dialogue with the owner of the X-Ray Café prior to four police cars arriving to block the lane and ten police officers in riot gear forming a faceless, speechless blockade directly in front of what had been a peaceful gathering?"448 Just a few days prior to the letter, Foxworth had been adamant that the heavy-handed police response was appropriate: "If we hadn't shown up, I think the situation would have gotten completely out of hand. You would have had unruly groups of thugs running the streets." 449

Absent from this anarchist incident was the conversation and compassion that was afforded to the Bloods. There was no impromptu dinner and no late night basketball matches. The Portland police dealt a swift and violent response to the anarchists. One could argue that this response was due to the anti-police stance of the protestors. Moose defended this response as well, stating that "I think the officers and command people that addressed that issue addressed it in the only way possible. They were going

\footnotetext{
446 Danks, “An Inevitable Clash of Ideologies," A 01.

447 Rick Bella, "Unexplained, Unexpected Shows of Riot Squad Force Unwanted," The Oregonian, 7/24/1993, B 03.

${ }^{448}$ Bella, “Unexplained, Unexpected Shows of Riot Squad Force Unwanted," B 03.

${ }^{449}$ Danks, “An Inevitable Clash of Ideologies," A 01.
} 
up against a group that it's their culture and code not to compromise and to not negotiate. When you talk about that your credence is anarchy, then where do you go from there?"450 One of the anarchists, Michael McKennan, disagreed. McKennan said in The Oregonian that, "I find it disturbing the police could have defused the situation by walking away, but they didn't." 451

Different communities, in other words, drew different policing tactics from Moose. The anarchists drew the full wrath of the law, while the Bloods drew compassion. Moose also expressed empathy for gang members who had lost a fellow comrade to a shooting. He said their emotions were similar to what a police officer felt when they lost one of their own in the line of duty. There was a commonality between these two groups. "We are angry, we want to have a confrontation with the perpetrator, we are somewhat confused about the 'Why,' because it all seems so hopeless," he said. "The compassion really struck me." 452

This essay will now examine three events that helped define how Moose's administration was associated with race in Portland, Oregon.

\footnotetext{
450 Manzano, "Portland's Police Chief Moose On The Loose," C 01.

${ }^{451}$ Meehan, "New Anarchists Not Bomb-Throwers, Associates Say," A 11.

452 Manzano, "Portland's Police Chief Moose On The Loose," C 01.
} 


\section{Chapter 5 - Moving to Northeast Portland}

"There is a misperception that people in the black community accept a certain level of crime." 459

-Charles Moose, 1993

In the early 1990s sections of North and Northeast Portland were dangerous, crime plagued areas of town. The local press did a spectacular job of presenting individual incidents to the larger public, further labeling these communities in the city's consciousness as "bad neighborhoods." Even the national television news networks perpetuated this theme. "Trouble always seems to be around the corner in Portland's North precinct, " is how CBS reporter John Blackstone introduced his news segment. ${ }^{460}$ $A B C$ News called the King Neighborhood "one of the city's most crime infested neighborhoods." 461 NBC News called it "a neighborhood of gangs and guns." 462 But it was not all just media "hype;" actual lives of citizens in those specific neighborhoods were being affected by crime. "Do you know anywhere where we can move to get away from this?," said a woman sitting on her porch on Vancouver Avenue as she saw the detective cars racing about, trying to find the shooter(s) of Torrey Carter. ${ }^{463}$

\footnotetext{
459 Michael Rollins and James Long, “Moose's Dedication Wins Katz," The Oregonian, 6/26/1993, A 01.

460 “Crime in America," CBS Evening News, CBS News broadcast, 11/22/1993.

${ }^{461}$ ABC News, World News Saturday, 11/27/1993

462 NBC News, "America Close Up" segment, 6/2/1994

463 James Mayer, "Shootings Leave 1 Dead, 1 Hospitalized," The Oregonian, 8/8/1993, C 07.
} 
Charles Moose demonstrated his commitment to community policing by flipping the accepted paradigm of the leading law enforcement officer in Portland when he moved into Northeast Portland. "I've been trying to convince people not to retreat, to stay in the city, to use the parks, to take back the streets," he said, "moving here seemed like the best way to walk the walk." 464

As chief, Moose also began a slogan of "No duty to retreat."465 In August of 1993, Moose addressed the City Club of Portland and explained that "The vision that I see is that you don't flee from your city. That as your city becomes at risk, as people try to move into your city and violate certain codes and standards and procedures, when people try to violate the laws that we've all agreed to live under, that you don't flee to the suburbs. That you don't stand up and say that this is just too difficult to try to defend. I'm going to move somewhere that it's safer. I'm going to move where things aren't so diverse. I'm going to move where everybody has a set of standards that I'm comfortable with. And I'm going to get out of the city." 466

Moose was encouraging families to stay within the city, and within the Portland Public School system, and not escape to the suburbs. In addition, Moose's process involved becoming more connected to one's community, and more connected to your neighborhood. As Barnes Ellis described the platform in the Oregonian, Moose wanted

\footnotetext{
464 Timothy Egan, "To Stay in Touch With Crime, A Police Chief Moves Near It," The New York Times, 12/25/1993, Sec. 1, 6.

465 Barnes C. Ellis, "Moose Exhorts Portlanders To Keep Their City," The Oregonian, 8/7/1993, B 04.

${ }^{466}$ City Club of Portland, "New Directions For Portland's Police Department." 8/6/1993.

https://www.youtube.com/watch?v=eP1UXxiVBqo\&feature=youtu.be
} 
adults to reach out and assist children, to look out for their neighbors, and not become disconnected by constructing literal fences. In the economic realm, Moose wanted to see businesses hiring minorities. ${ }^{467}$ Moose worked with the City's intelligentsia and policy advisors, and laid out his platform of community policing in Portland.

Some critics of the programs were concerned that living in the neighborhood would provide the police officers no respite from work. An Oregonian editorial warned that "Police are never really off duty wherever they live." 468 Jeff Baker, president of the Portland Police Association said, "I think the only concern will be for people to not look at the officer as the neighborhood cop, on duty 24 hours a day. It will be their home."469 Burn-out was a concern.

Moose clearly was not oblivious to the conditions of the neighborhood where he decided to make his home. "I knew the statistics when we moved in, and I knew the area. But people tend to drive up their own fear." 470 Yet, he obviously saw the benefit of having police officers living within these communities. As PPB Bureau Commander (North/St. Johns) Alan F. Orr said, "When you are close to the community you serve, you get a feel for the people and their problems." ${ }^{471}$ Much like his early experiments with community policing, Moose was able to form an action plan to help get officers from living in communities outside of Portland and into these urban areas of the city.

\footnotetext{
467 Ellis, “Moose Exhorts Portlanders To Keep Their City," B 04.

468 Editorial, "Securing Troubled Housing," B 06.

${ }^{469}$ Fentress, "Loan Plan Urges Officers To Live in Target Areas," B 01.

${ }^{470}$ Egan, "To Stay in Touch With Crime," Sec. 1, 6.

${ }^{471}$ Fred Leeson, "Preserving The Precinct," The Oregonian, 3/30/1994, C 01.
} 
However, the City of Roses needed some sort of financing option to incentivize Portland police officers to relocate into the communities where they policed.

By late 1993, ten cities had instituted a similar program to move officers into their high-crime neighborhoods, and 140 cities were considering such a plan. ${ }^{472} \mathrm{~A}$ few months later, the Department of Housing and Urban Development acknowledged that sixty programs were being administered nationwide. ${ }^{473}$ In Columbia, South Carolina, nine police officers moved into a crime-ridden area. They were able to secure twenty-year home loans at four percent interest, based solely on a credit check. ${ }^{474}$ In Ohio's Lucas County, officers were offered apartments in public housing programs for one dollar a month. ${ }^{475}$ The entrenchment of the officers encouraged neighbors to give more attention to their properties. As a result, property values in the community rose, commercial activity saw an uptick, and as reporter Don Williamson noted, "Nine more police officers have moved inside the city limits and gained an instant vested interest in what goes on there." ${ }^{477}$ Portland, however, had no existent low interest program for officers at the time. In essence, Chief Moose started one, and consistent with his management style, he decided to lead by doing. He just moved in. ${ }^{478}$

\footnotetext{
472 Don Williamson, “King Neighborhood Needs Chief Moose, Many More," The Oregonian, 12/6/1993, A 11.

473 Editorial, "Securing Troubled Housing," The Oregonian, 5/2/1994, B 06.

474 Williamson, "King Neighborhood Needs Chief Moose," A 11.

475 Editorial, "Securing Troubled Housing," B 06. In early 1995, Seattle had a similar housing incentive program that was available for firefighters as well as police officers. See Aaron Fentress, "Loan Plan Urges Officers To Live in Target Areas," The Oregonian, 2/7/1995, B 01.

477 Williamson, "King Neighborhood Needs Chief Moose," A 11.

478 Williamson, “King Neighborhood Needs Chief Moose," A 11.
} 
During the question and answer portion of Moose's City Club of Portland speech, the chief was asked about the incentive programs that other cities had regarding police officers moving into the city, and if Portland was discussing a similar program. Moose replied that he was not aware if that conversation was actively taking place, but stressed that he would certainly like to have some of those conversations. ${ }^{485} \mathrm{He}$ noted that there had been some previous considerations, but that they had "never really turned into anything real." 486 "But," he added, "there does need to be some type of program to assure that we get some of those vacant houses and vacant lots in our inner city occupied, and I think it would certainly be appropriate if they were occupied by police officers." 487

By this point, in August of 1993, more than half of the bureau's officers lived outside the city of Portland. ${ }^{488}$ By February of 1995, that disparity had increased. Of 1,006 sworn officers, only 341 lived in Portland's city limits. ${ }^{489}$ Moose realized the power that these statistic held. Moose said in 1994 that, "Police officers, again are being held in high esteem throughout the country, and people are watching what we're doing. Once we declare a neighborhood not safe enough to live in, and we move out, well anybody in their right mind looks at that and says, 'I should probably do the same thing.'"490

\footnotetext{
485 City Club of Portland, “New Directions For Portland's Police Department." 8/6/1993.

${ }^{486}$ City Club of Portland, "New Directions For Portland's Police Department." 8/6/1993.

${ }^{487}$ City Club of Portland, "New Directions For Portland's Police Department." 8/6/1993.

488 Editorial, "Hometown Police," The Oregonian, 8/13/1993, C 08.

${ }^{489}$ Fentress, "Loan Plan Urges Officers To Live in Target Areas," B 01.

490 NBC News, "America Close Up" 6/2/1994
} 
As Moose noted in his City Club speech, the city had expressed a desire to have Portland Police Bureau officers living in the city of Portland in the past. In 1989, The Oregonian had called for the city council to consider residency incentives. ${ }^{491}$ They considered such a program a "crime-prevention strategy." 492 The paper observed two main benefits to the community from this initiative. One was disaster response. The editors noted that in San Francisco, first responders were late in reacting to earthquake incidents, as they lived outside of the city, and found it difficult to get back into the metropolitan area due to the damage and confusion. But looking locally, the paper also felt that Portland's community policing pledge "requires a concern and full-service commitment more likely to be seen in a neighbor than in a commuter from the suburbs." 493

The editors mentioned that in 1988 Commissioner Earl Blumenauer had called for a task force to look at hiring incentives that would favor city residents. Unfortunately for the community, the paper claimed, Mayor Bud Clark had "ducked" investigating a program that would give "hiring and promotion bonus points based on residency." 494

"You don't flee from your city."495

-Charles Moose, 1993

\footnotetext{
491 Editorial, "Hometown Police," C 08.

492 Editorial, "Hometown Police," C 08.

493 Editorial, "Hometown Police," C 08.

${ }^{494}$ Editorial, "Hometown Police," C 08.

495 Ellis, "Moose Exhorts Portlanders To Keep Their City," B 04.
} 
On Thanksgiving weekend, 1993, Moose and his family moved into the "fixer-upper" he bought in the King neighborhood. ${ }^{496}$ The craftsman bungalow was built in $1911 .{ }^{497}$ The 2,000 square foot, three bedroom home featured hardwood floors, fir moldings and leaded glass windows. ${ }^{498}$ The price of the home was $\$ 80,000$ - a comparable Portland Heights residence might have fetched $\$ 200,000$ to $\$ 300,000$ at the time. ${ }^{499}$ But Moose's home was far from the seclusion and exclusivity of the West Hills- his new home was a half a block from Martin Luther King Jr. Boulevard.

The new Moose home was indeed in a rugged neighborhood - a drug house, located just around the corner, had been shut down just a few years prior to the purchase. ${ }^{500} \mathrm{~A}$ boarded up vacant house was across the street. The former home owners of Moose's new home had been robbed several times, and one had been mugged while on a walk. A Molotov cocktail had once been thrown at the home. In fact, when Moose was first

\footnotetext{
496 Williamson, “King Neighborhood Needs Chief Moose," A 11.

497 Elisabeth Dunham, "Charles Moose, Portland police Chief, On His Comfy Living Room" Homes \& Gardens of the Northwest Special Home Style Edition, The Oregonian, 9/18/1997, 31.

498 Holly Danks, “Moose Buys Into The Bid To Take Back The Street," The Oregonian, 11/10/1993, A 01.

${ }^{499}$ Editorial, "Revisit Portland Redlining," The Oregonian, 11/14/1993, D 01. If Moose had held onto the home, his returns would have been quite significant. The website Portland Maps has the house at 422 NE Going selling in October 2013 for $\$ 442,000$. http://portlandmaps.com/detail.cfm?action=Assessor\&\&propertyid=R239973\&state id=1N1E23BC $\% 20 \%$ 2015701\&address $i d=584841$ \&intersection $i d=\& d y n a m i c$ point $=0$ \&place $=422 \% 20$ NE\%20GOING\%20ST\& city=PORTLAND\&neighborhood=KING\&seg id=107659\&x=7648662.432\&y=696287.616 (DOC 4/9/15) In April of 2016, the popular real estate estimate site listed the former Moose home as having a market value of $\$ 553,661$. http://www.zillow.com/homes/for sale/422-NE-Going-portland,oregon $\mathrm{rb} /$ ?from HomePage=true\&shouldFireSellPagelmplicitClaimGA=false\&fromHomePageTab=buy (DOC 4/15/29016)

500 Editorial, "Revisit Portland Redlining," D 01.
} 
touring the house with the listing agent, a pimp dropped off a prostitute right outside the home. ${ }^{501}$

Describing the condoms and hypodermic needles on the ground around the house, Moose paints the scene: "The house itself, which had sat empty for six months, was rat infested. It had an odd smell - the result, we were told, of a tenant-landlord dispute that ended with the tenant dumping over a ton of manure onto the hardwood floors in the living room." 502

The immediate vicinity of the new Moose home was a microcosm of Northeast Portland - a block-sized perspective of the crime, the drugs, and the other vices of 1990s Portland. But on a slightly larger scale, the statistics for the King neighborhood were sobering. The Moose home was not an isolated address of crime. The neighborhood was comprised of about 3,000 houses and roughly 7,000 residents. ${ }^{503}$ In an ABC News segment about Moose's move, the reporter noted that in 1992 the King neighborhood had experienced three murders, 139 burglaries, and 322 assaults. ${ }^{504}$ From January to August 1993, the neighborhood experienced almost twice the normal city neighborhood crime rate (160 crimes per 1,000 King residents, as opposed to 86.5 crimes per 1000 in other Portland neighborhoods). ${ }^{505}$ The neighborhood had the highest

\footnotetext{
501 Danks, “Moose Buys Into The Bid," A 01.

502 Charles Moose and Charles Fleming, Three Weeks In October; The Manhunt For The Serial Sniper, (Waterville, Maine: Thorndike Press, 2004), 388.

503 Phil Manzano \& Dave Hogan, “Reno Tours Portland Chief's Neighborhood," The Oregonian, 6/14/1994, B 01.

${ }^{504}$ ABC News, World News Saturday, 11/27/1993

505 Danks, “Moose Buys Into The Bid," A 01.
} 
homicide and unemployment rates in Portland, as well as the largest number of abandoned or empty buildings. ${ }^{506}$

But Moose was all in. He had come to the King Neighborhood to improve the lives of his neighbors. This was not the result of a decision of a strategic plan steering committee. There were no board rooms and felt-bottomed coffee coasters for Moose's planning sessions. This was a new, untested attempt at a civil reengineering of Portland, but in a manageable, bite sized portion of the city. Moose was implementing new concepts and theories of community policing, and he was doing the heavy lifting. When Moose stated on national television, "maybe we've been thinking on too grand of scales, and trying to change whole cities when maybe we take it one house as a time," it seemed as if this was still an idea that was in its infancy and still developing. ${ }^{507}$ The chief was personally invested in his own doctrine, and he was going to test his principles to effect change. Moose said, "I spend so much time telling people they need to be a part of taking back the streets one at a time, I felt I needed to part of that." ${ }^{508}$

Moose had done this before at Iris Court. He had personally affected social change through the interpretation of theories of community policing, and then the implementation of his "on the ground" plans. He was very well-versed, and quite accomplished in, this process. His depth of theory was bolstered by his doctorate in

\footnotetext{
${ }^{506}$ Moose and Fleming, Three Weeks In October, 389.

507 "Crime in America," CBS News, 11/22/1993.

508 Danks, “Moose Buys Into The Bid," A 01.
} 
urban studies. But unlike Iris Court, there was no federal grant to fund this King neighborhood project. This was done in his own free time, before and after work; and he made little touch points into his community channeled through the block that he lived on. As Oregonian reporter Don Williamson wrote, "It is more of a personal oddity for one family than a challenge to the greater community to accept the responsibility for what happens in their corner of the planet." 509

Not that the process was easy. Moose said that he and his wife experienced something like redlining while attempting to purchase their new home. He stated that several Portland real estate agents "just refused to show (Mrs. Moose) any properties in the area where we were intent on moving, so we could do our part to make that neighborhood a better place." 510 "Not the kind of neighborhood for a police chief," was heard from several real estate agents. ${ }^{511}$ As The Oregonian reflected later, "Although Moose had previously lived in Northeast Portland, this move was clearly out of the ordinary. Chiefs had lived in the suburbs, or in well-to-do sections of town."512 Ultimately, the Mooses abandoned the service of agents and found their home themselves. "Quite frankly, we just had to finally go around and find the property and then call direct to the listing agent," he said. ${ }^{513}$

\footnotetext{
${ }^{509}$ Williamson, “King Neighborhood Needs Chief Moose," A 11.

510 Editorial, "Revisit Portland Redlining," D 01.

511 Danks, "Moose Buys Into The Bid," A 01.

512 Tom Hallman Jr., "Mr. Moose's Neighborhood: Children Know Portland's Police Chief As A Friend," The Oregonian, 1/19/1995, A 01.

513 Danks, "Moose Buys Into The Bid," A 01.
} 
Moose wanted his message and his move to both be authentic. He wanted to become a participating member of the community, and to be a leader for others to emulate. "Being part of that community makes my message a real message. But it also says that the people in and around my house don't have to worry about my house being a crack house." ${ }^{514}$ Improvement or enhancement was absolutely a key point of Moose's plan. In talking about the depressed neighborhood, Moose said that he and his wife, Sandy, "wanted to be a part of the revival, to be part of the healing of the community. We wanted to set an example, and we hoped that other people would follow our example." 515 A few years later, Moose felt it was "the right move," and his wife, Sandy, felt that "their presence has had a positive influence. ${ }^{516}$

Moose's unilateral move, made without incentives, caused pause and a moment of reflection within the city. Again, the daily paper called the City Council to task for not instituting a program to help more officers make a similar move to Moose's relocation: "The City Council should explore incentive and hiring policies that would encourage more police to live in the community they serve." 517 The paper also asked Mayor Katz, and Housing Commissioner Gretchen Kafoury, and real estate professionals to heed Moose's redlining experience and challenge thier practice. "Stop the subtle and not-sosubtle redlining that strangles Portland neighborhoods," the paper demanded. ${ }^{518}$

\footnotetext{
${ }^{514}$ ABC News, World News Saturday, 11/27/1993

515 Moose and Fleming, Three Weeks In October, 389, 390.

516 Dunham, "Charles Moose, Portland police Chief," 31.

517 Editorial, "Revisit Portland Redlining," D 01.

518 Editorial, "Revisit Portland Redlining," D 01.
} 
For many in the community, the move was seen as an example of Moose's take charge leadership style, his leading by example, his wanting to really get a pulse on what was happening on the street (like when he worked the streets as a patrol officer at the car crash just after being appointed chief). Many heralded the move. Neighbor Steve Foust called Moose's move "symbolically important." 519 The editor at The Portland Skanner said that "Moose shows himself as someone who is willing to invest in the northeast Portland community's success in the most fundamental way." 520

Some were less excited about the prospect, feeling it "mostly symbolic, but appreciated... nonetheless." 521 New neighbor Lenora Jeanmarie was a bit ambivalent about it all. She said she would take "anybody as a neighbor, as long as they were decent. Charles Moose or President Clinton can move in here. It's no worse than any other neighborhood." 522 Edna Robertson, executive director for the Northeast Coalition of Neighborhoods said, “I don't think because Charles Moose is moving into my neighborhood crime is going to stop overnight. When crime happens on the street, until the city cleans it up, my neighborhood is not going to be safer than anybody else's." 523 The local Crips gang seemed less than enthused as well. They spray painted a message for the chief in his front yard. ${ }^{524}$

\footnotetext{
519 Manzano and Hogan, "Reno Tours Portland," B 01.

520 Author Unknown, "Police Chief Sets Example For All," The Portland Skanner, 11/24/1993, 4.

${ }^{521}$ Maxine Bernstein "Moose Closes Out 6-Year Tenure of Achievement, Pitfalls as Chief," The Oregonian, 7/28/1999, A 01.

522 Danks, "Moose Buys Into The Bid," A 01.

523 Danks, "Moose Buys Into The Bid," A 01.

${ }^{524}$ Egan, "To Stay in Touch With Crime," Sec. 1, 6.
} 
There was some hope from the community that other Portland police officers would join Moose in his move back into the city. The Portland Skanner editors wrote that "other officers are sure to follow such a bold and committed example of becoming a part of the communities most in need of their presence as neighbors, not enemies." 525 Many Portland police officers, however, were skeptical of the move. As Timothy Egan, a New York Times reporter wrote, "it is hard to tell what effect, if any, Mr. Moose's decision will have on other officers. Those who do not roll their eyes when asked about it, give the chief positive remarks."526

Moose knew that his move could cause such a reaction from his force. "The officers who are supportive say things like, 'We're really worried about you and Sandy,' but what they're really saying is, 'Jeeze, that's the stupidest thing you could ever do.'" 527 In one precinct, a newspaper photograph of Moose pointing to his new home was hung on the wall. Someone had written under the photo, "Chief Moose pointing in the direction of his VCR." 528 In another case, someone wrote graffiti in a precinct house that said, "The chief's moving in his ho' and turning her out." 529 About a year later, while the chief was out of town at a conference, Sandy received an early morning phone call. The anonymous caller said, "Nobody fucks niggers," and then the line went dead. Sandy

\footnotetext{
525 "Police Chief Sets Example," 4. Jim Cummins of NBC News said in his report that Moose hoped that this stretch of influence would extend well past the Portland area. "That's why this police chief [Moose] is hoping police officers nationwide will follow his example and move back into the high-crime neighborhoods they patrol every day," Cummins reported. NBC News, "America Close Up," 6/2/1994.

${ }^{526}$ Egan, "To Stay in Touch With Crime," Sec. 1, 6.

${ }^{527}$ Egan, "To Stay in Touch With Crime," Sec. 1, 6.

${ }^{528}$ Egan, "To Stay in Touch With Crime," Sec. 1, 6.

${ }^{529}$ Moose and Fleming, Three Weeks In October, 390.
} 
called the department and filed a complaint. The officer who came to the house to fill out the report asked Sandy point blank, "What did you expect, moving into that neighborhood like you did?"530

But nationally, Moose's move was capturing attention. The New York Times featured an article on his move, and all three national networks featured news segments on Charles and Sandy's new home. In June of 1994, United States Attorney General Janet Reno was in Portland to address the U.S. Conference of Mayors. Her intention was to promote a $\$ 20$ billion crime bill under consideration in Congress. One of the provisions of the proposed legislation was money for officers to live in the communities where they worked. ${ }^{531}$

Before the conference, she took the opportunity to tour the King Neighborhood with Chief Moose, and to discuss community policing and officers living in the communities they policed. Attorney General Reno spent about 15 minutes speaking privately in the Mooses's home, with Charles and Sandy, and Mayor Vera Katz. ${ }^{532}$

A 1994 article discussing increasing property values in North and Northeast Portland attributed the 10 to 28 percent rise to an uptick in the perception of North Portland. The Oregonian declared that "the image of an area under siege is yielding to the more realistic image of normal, Cleaveresque lifestyles, the foxhole mentality is gone." In a

\footnotetext{
530 Moose and Fleming, Three Weeks In October, 390, 391.

531 Manzano and Hogan, "Reno Tours Portland," B 01.

532 Manzano and Hogan, "Reno Tours Portland," B 01.
} 


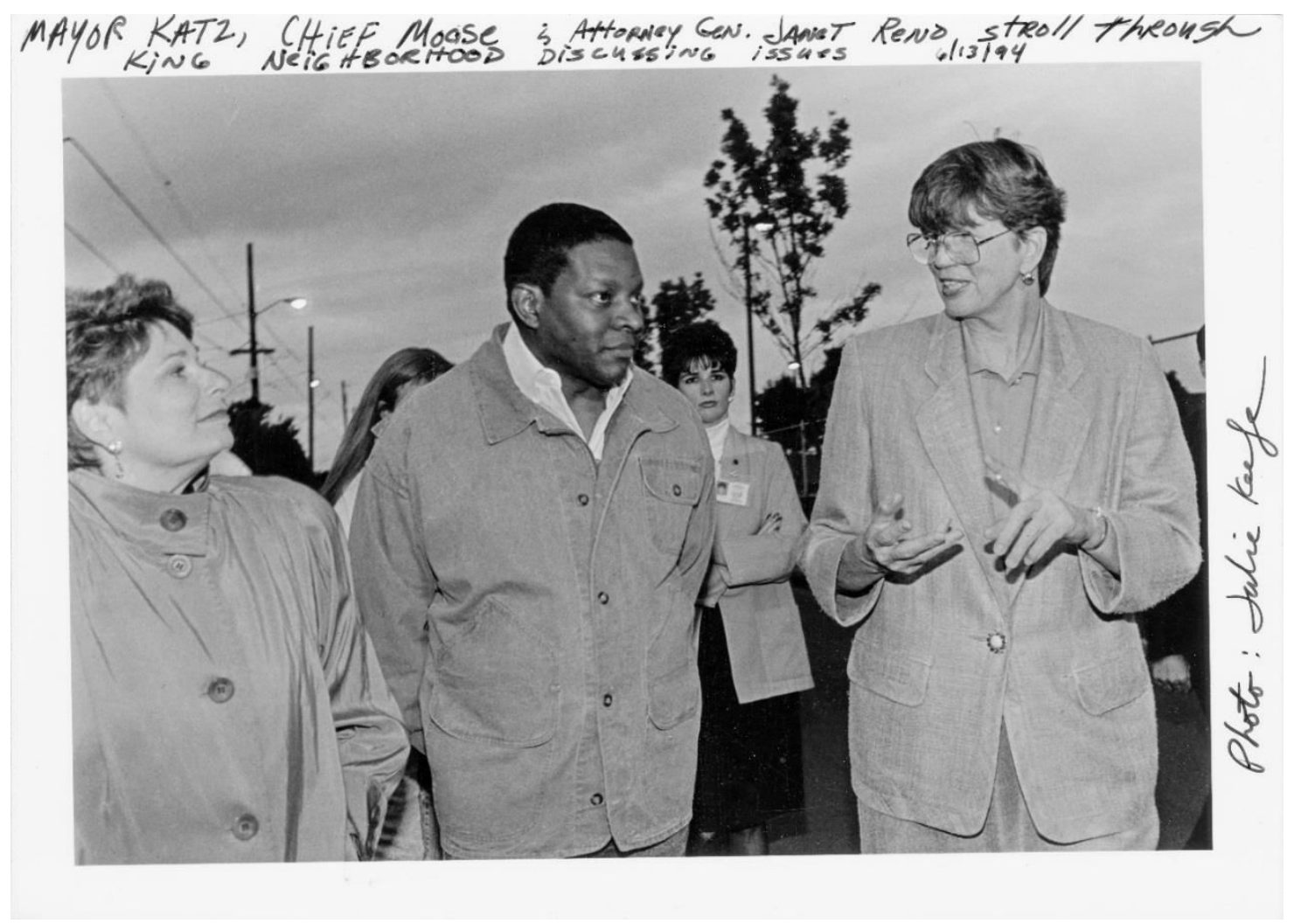

Figure 11 Mayor Katz, Chief Moose and Attorney General Reno walk through the King Neighborhood. Courtesy of Oregon Historical Society, Image bb013800.

pointed jab at the situation, the article continued that "Heck, the logic goes, if it's good enough for Police Chief Charles Moose." 533

And, in many ways there was a Cleaveresque aspect to the transformation. Moose would often sit on the porch of his home, chatting with neighborhood children. ${ }^{534}$ Roy Washington, a resident of Northeast Portland, said "he kind of helped balance things

\footnotetext{
533 Norm Maves JR \& Wade Nkrumah, “Goin' North,” The Oregonian, 10/17/1994, B 01.

${ }^{534}$ Erin Hoover, "Moose Drops Out of Cops Job Selection," The Oregonian, 09/17/1994, A 01.
} 
and make contact with this community. You might see him out in his yard and stop and talk. He made himself open." 535

But it certainly was not all smiles and sunshine in the King Neighborhood just because the chief had moved in. At 11:30 PM, one night in early 1994, Moose heard a noise on his front porch. He went outside and found a woman who had just been beaten up by a man on Martin Luther King Jr. Boulevard. She knew that Chief Moose lived in the house and ran there for his assistance and safety. ${ }^{536}$

Moose was devoted to his micro project, and it appears that he put off further career advancement because of his commitment in his community. Moose, along with former Portland Police Chief Tom Potter, had been considered to be on Attorney General Janet Reno's short list for the Federal Community Oriented Policing Services (Cops). Interestingly, Moose withdrew his name from consideration for a federal posting. ${ }^{537}$ In explaining why he had decided to withdraw, Moose said, "I am honored to have been considered for this position, and it certainly indicates that the Portland Police Bureau is looked to as a leader in community policing. I am also very honored to be the Chief of Police in Portland, and to be involved in the successes that the Bureau and neighbors are making every day." 538

\footnotetext{
535 Bernstein “Moose Closes Out 6-Year Tenure,” A 01.

536 Holly Danks, "No Thanks, Chief," The Oregonian, 3/28/1994, B 01.

${ }^{537}$ Hoover, "Moose Drops Out," A 01. It is important for the reader to consider what a prominent posting the Cops position would have been for Moose. Just to be considered as one of the three finalists was a huge, national recognition of his work with community policing.

${ }^{538}$ City of Portland Archives, B/030226, 24-02-15, Subject Files, Police: Mayor's Office, 1993-1996, Police Related Press Releases/Video Tapes, file "July - Oct," "Chief Moose Withdraws Name From Consideration
} 
But the real reason for his withdrawal from that prestigious posting were the connections he had made through his new home in the crime-ridden area. Moose said, "After some long conversations with my wife, I decided this is our home. Our house in the King Neighborhood and the things we are trying to do there with the young people are very, very important to us. That work is nowhere close to being done. It's just a terrific feeling when there's the possibility of changing a life for some of those young people." ${ }^{539}$ Moose's relocation had become a part of his identity, his calling.

He was a leader for this community, and his agenda was driving economic and social development. In a letter to Attorney General Reno, announcing his intention to withdraw, Moose was quite clear on the reason: his community policing project was paramount. Moose wrote that, "The citizens of Portland have accepted a partnership with the police and the men and women of the Bureau have been working with neighbors to solve community problems. Sandy and I truly enjoy being a part of these efforts." 540 Even local business acknowledged their pleasure with Moose's move. In a June, 1994 letter to the chief about crime in the NE Alberta and Albina area, Tim Rich, Project Manager, and Julia Spence, Communications Manager of Neil Kelly designers,

For Crime Bill Position," 9/16/1994. Nor would this be the only time Moose entertained the idea of leaving Portland while chief. In 1997, his name was tossed around as a consideration for chief of the Houston police department. Moose had also applied for the position of chief of police in Washington D.C. in January 1998. David Anderson, "Portland's Top Cop Under Fire From His Own Force," The Oregonian, 10/26/1997, A 01, and Susan Gage, "Moose Seeks Job As Chief In Capital," The Oregonian, 02/18/1998, A 01.

539 Hoover, "Moose Drops Out," A 01.

${ }^{540}$ City of Portland Archives, B/030226, 24-02-15, Subject Files, Police: Mayor's Office, 1993-1996, Police Related Press Releases/Video Tapes, file "Jan-March 1994 News Release" "Letter to Atty Gen Reno from Charles Moose," 9/16/1994. 
wrote "we know of your personal commitment to North/Northeast Portland." 541 Moose became very involved with the community. These were indeed his neighbors, and this was his community.

"Since Charles Moose took over - the police officers treat citizens with respect something they never did with our last Chief of Police."

- Citizen Joyce Nelson, 1997

Moose was quite involved with the SMART (Start Making a Reader Today) program. The program, started by Oregon Governor Neil Goldschmidt, involved giving a book to kindergartners and first and second graders in twenty schools throughout North, Northeast, and Southeast Portland. Participants contributed time to read to two children every week. Chief Moose volunteered with the program and described personally experiencing the children's excitement for learning. ${ }^{543}$ Moose found his working with the children in the community to be extremely rewarding. In fact, he made occasional pleas to other police officers to become involved with the program. In his regular "Chief's Corner" section of PPB's The Bulletin, Moose asked officers to volunteer a half an hour a week to help children refine their reading skills. Moose also explained a deeper community connection that participants could obtain with the program: "Your work with the kids not only improves their reading and listening skills, but it also shows

\footnotetext{
${ }^{541}$ City of Portland Archives, Neil Kelly letter dated 6/23/1994.

542 City of Portland Archives, B/030042, 40-12-40, Subject Files, Mayor Katz, Sam Adams Police-Public Correspondence, Executive Orders, Campaigns, 1997-1998. Letter from Joyce Nelson to Mayor Vera Katz, 10/26/1997.

${ }^{543}$ City of Portland Archives, B/030229, 24-03-36, Subject Files, Police: Mayor's Office, 1993-1998, Box 2, file "The Bulletin," “Chief's Corner," The Bulletin, 9/10/1998.
} 
them that you care about them as people. And when they find out that you work for the Police Bureau, your involvement takes on a greater depth of meaning to them."544

This was not just some missive from PPB Human Resources, offering feel-good opportunities to employees of a large organization. And, while this was representative of Moose's individual ideas about community policing, it was also coming from the chief's heart. It was a connection that Moose personally sought out with the children of North and Northeast Portland. In a June 1994 NBC segment of America Close Up, Moose visited a fourth grade King Neighborhood class that had "adopted" him for the year. As Moose stands in front of the children, he tells them, "One of the reasons that I wanted to come this year, and be part of your year, is to let you know that as a police officer that I love you, and I care about you." 545 Moose's sentiments in the video seem genuine.

As he tried to get more officers and nonsworn employees of the bureau into the classroom, Moose pointed out that the employee's time in SMART activities was considered service to the community and was an "authorized part of the workday." 546 He urged managers "to support this program and make every effort to adjust schedules and workloads to ensure that volunteers can complete their SMART assignments." 547 Through this policy, Moose was able to continue to implement his theories of community policing throughout affected areas of the city of Portland. Moose explained:

\footnotetext{
${ }^{544}$ City of Portland Archives, "Chief's Corner," 9/10/1998.

545 NBC News, "America Close Up" 6/2/1994

${ }^{546}$ City of Portland Archives, "Chief's Corner," 9/10/1998.

${ }^{547}$ City of Portland Archives, "Chief's Corner," 9/10/1998.
} 
"As we look to the future of community policing and the long-range goals of the Police Bureau, I cannot help but feel that community service above and beyond our normal workload will always be a priority. And though each of us in some way fulfills that community service each day by just doing our jobs, programs such as SMART allow us to do just a little bit more. Not only does it give us a break from our own issues, it provides a different perspective on our lives.... We can make a difference." 548

Moose could make grand, sweeping statements about his policy. On national television, he explained that "I'm committed to make a difference, and I get my one trip through this life, and I think I need to do something with it." ${ }^{\prime 549}$ But Moose's most important impact on his community, his individual implementation of community policing was best orchestrated on an almost micro level. He was best able to enact his personal community policing principles right in front of his home. At 8:20 every weekday morning, a yellow school bus would stop and pick up children for Harriet Tubman Middle School. ${ }^{550}$ A group of up to 25 children would gather. Just after they moved in, Moose detailed, "I kept an eye on the kids. After about a week I went outside and talked with them. I told them who I was and said they could stay there if they stopped throwing gum wrappers on my lawn." ${ }^{551}$ Needless to say, the discarded gum wrappers disappeared. Tony Scribner, aged 14 at the time, said "We were kind of scared

\footnotetext{
548 City of Portland Archives, "Chief's Corner," 9/10/1998.

${ }^{549}$ ABC News, World News Saturday, 11/27/1993

${ }^{550}$ Hallman, "Mr. Moose's Neighborhood," A 01.

${ }^{551}$ Hallman, "Mr. Moose's Neighborhood," A 01.
} 
of him at first. I mean, he was the chief. He might have got us arrested for throwing those wrappers."552

Charles and Sandy Moose talked to the children and got to know them as individuals. In the summer, the Mooses paid the children to do odd jobs around the house. Sandy would bring the children diet sodas and candy bars. Connections were formed and more exchanges took place. Charles noted somewhat forlornly that the children knew first hand way too much about violent crime. "They described things in details that I wish they didn't know. But they do know it." ${ }^{\prime 53}$ The children learned that the police were just people and that police officers could be positive forces in their lives. They could even be nice. Tim Zimmer, a fourteen year old boy noted, "When he's in his police uniform we call him Chief Moose. But when he's out of his uniform it's polite to call him Mr. Moose."

The children often saw Mr. Moose wash his car or mow the lawn. They wondered why he did that himself and why he did not have paid help take care of the menial tasks. Moose told the children that he did his chores because he took pride in his things. "That answer" he said, "threw them for a loop." 554

The children learned the roles of the police in their community; and in true community policing fashion, Moose was able to show the children that policing is a

\footnotetext{
552 Hallman, "Mr. Moose's Neighborhood," A 01.

553 Hallman, "Mr. Moose's Neighborhood," A 01.

${ }^{554}$ Hallman, "Mr. Moose's Neighborhood," A 01.
} 
team effort. For example, one day, when Moose and the children were chatting, a car sped past. The children asked why Moose had not jumped into his car, chased the culprit down, and issued a ticket. Moose said, "I told them that I'm just one person in the bureau and I'm not fighting crime all the time." 555 But the opportunity was then presented for Moose to ask the children to reflect upon the fact that soon they would be of driving age. He asked them to consider how they planned to conduct themselves as drivers. This was Moose at this finest - connecting with his community right on his front porch, and seizing a teachable moment that physically came screaming past on the way up Martin Luther King Jr. Blvd. This was classic community policing.

The Portland Skanner had predicted this possibility when they wrote about Moose's controversial move in November of 1993. "Too often youth have no one in their neighborhood who is successful that they can identify with. However, when success lives across the street, it becomes close enough to see clearly." 556 The Mooses absolutely wanted this association to be visible and public. As Sandy Moose said on CBS Evening News, "I just think it'll be great for every kid at the school to just know that the police chief lives right there." 557

Moose reflected on his relationship with the children. He knew it was temporal, and the impression he could make on the children was fleeting at best. "All I hope is that

\footnotetext{
555 Hallman, "Mr. Moose's Neighborhood," A 01.

556 "Police Chief Sets Example," 4.

557 “Crime in America," CBS News, 11/22/1993.
} 
someday they remember what we talked about, what I said. I hope that at some point in their lives they remember that I was a small part of it," Moose said.

When reporter Tom Hallman wrote of the relationship between Moose and the local children, he recounted a particularly poignant morning when a child had left their books on the chief's lawn. Moose had been running late for his busy day. He had a multitude of important decisions to be made and important people needing his assistance with a myriad of crises. But at this point - all of those needed to wait, as the importance of Neighbor Moose getting the lost books to Tubman school outweighed the responsibilities of Chief Moose. Moose took the books, put them on the front seat of his car, and drove to the school to drop them off.

Moose's blueprint of community policing in action did not just end with the children of his King neighborhood. Moose was also able to enact his version of individual community policing, right in front of his home, right on his block, in one of the most economically depressed neighborhoods in Portland. Moose described two such incidents in his book. Jamie Partridge was Chief Moose's mail carrier. One day Moose noticed that Partridge's uniform was looking a little "raggity" - the knees on his pants were thin and the pockets were torn. Moose asked him why his uniform was in such a sad state, and the postman explained that the U.S.P.S. uniform allowance had been late. Moose knew that Partridge shopped at the same local store as he did for his police 
uniforms, so the chief spent $\$ 50$ and bought him a new pair of mail carrier uniform pants. ${ }^{558}$

Like the battered prostitute detailed earlier, other Portlanders sought out the chief's assistance. In 1995, an eleven-year-old neighborhood boy named Detrick Mans reached out to Moose about his ten speed bike. The bike had been stolen from the Matt Dishman Community Center on NE Knott Street. The bike had cost $\$ 130$, and Detrick's working class family did not have the money to replace it. Moose was the only police officer that Detrick knew, so he asked him for help. ${ }^{559}$ The family had not recorded the serial number for the bike, and Moose knew there was no hope in returning the bike.

Moose had been paid $\$ 500$ by Reader's Digest for an article he had written about his move to the rough neighborhood. Moose met with some of his contacts at Fred Meyer, a local department store, and they agreed to match that $\$ 500$ in a bike program for Detrick's classroom. The children were asked to write an essay about how they would use a bicycle to assist with community policing, and the best seven essays would win a new bicycle. Moose visited the classroom, and "I told them I wanted them to do their best, to write their essays in ink and in their best handwriting. I told them their essay should be the best work they could possibly do." ${ }^{560}$ The top seven essays were selected, an awards ceremony was held, and two girls and five boys, one being Detrick, were

\footnotetext{
558 Moose and Fleming, Three Weeks In October, 395-397.

559 Moose says he "didn't know if he knew I was the police chief, or if he just thought I was another cop. But he trusted me, and he came to me for help." Moose and Fleming, Three Weeks In October, 393.

${ }^{560}$ Moose and Fleming, Three Weeks In October, 394.
} 
awarded the new bicycles. As Moose wrote, "Community policing had opened many doors and affected many lives." 561

As Moose told the stories of Detrick Mans and Jamie Partridge, he observed that he was in a position of authority, influence, and economic comfort that enabled him to assist. He had privilege. "Things like that, making that kind of change, one-on-one, neighborhood level, were possible to me." ${ }^{562}$ Moose was changing the lives of a few individuals that he lived near and interacted with in his neighborhood. His strategic policies were issued to hundreds of officers across Portland, and they policed across the city and affected large swaths of streets, buildings, and homes. But this was right off of his porch - right on his corner - not an 8,000 foot view, heady academic, or Washington D.C. think tank theory. This was NE Going Street, right off of MLK. Moose learned from the process as well. He wrote of Mans and Partridge, "It's not a big thing. But they're both good examples of the kind of police work I was able to do as a result of the community policing idea, and as a result of how the community policing changed $m y$ idea of what a police officer could do."563

Not all of Chief Moose's block based efforts at individual community policing were successful. The Mooses also offered up their home as a Block House, which was a program that provided a patchwork of safe houses for children who needed temporary

\footnotetext{
561 Moose and Fleming, Three Weeks In October, 395.

562 Moose and Fleming, Three Weeks In October, 397.

563 Moose's emphasis. Moose and Fleming, Three Weeks In October, 397.
} 
refuge from trouble on the streets. ${ }^{564}$ The Mooses were refused in their offer, as the city's crime prevention coordinator, Sharon McCormack, knew that the chief often was at meetings and working late at the office when the program would need an occupied block house. ${ }^{565}$

In May of 1994 the Portland Police Bureau and the Portland Housing Authority began discussing ways to help encourage PPB officers to move into targeted, high crime communities. The Cambridge and Iris Court Apartments were initially selected. ${ }^{566}$ Those locations were not the most appealing developments for an officer to raise their family. Something more needed to be done.

Clearly, Moose saw the benefit of having sworn officers in affected neighborhoods, as living, breathing, thinking, and caring extensions of his strategic plan of community policing. The benefit that a neighborhood could achieve by having a visible, active, and professional police officer living in the community was self-evident to the chief. But many officers, living on a civil servant's paycheck, did not have the means necessary to commit to such a program in the way the chief had. The city needed a strategic plan to place police officers throughout the affected areas, and there needed to be some incentive to encourage them to make this major life change.

\footnotetext{
564 Danks, “No Thanks, Chief," B 01.

565 Danks, "No Thanks, Chief," B 01.

${ }^{566}$ Editorial, "Securing Troubled Housing," B 06.
} 


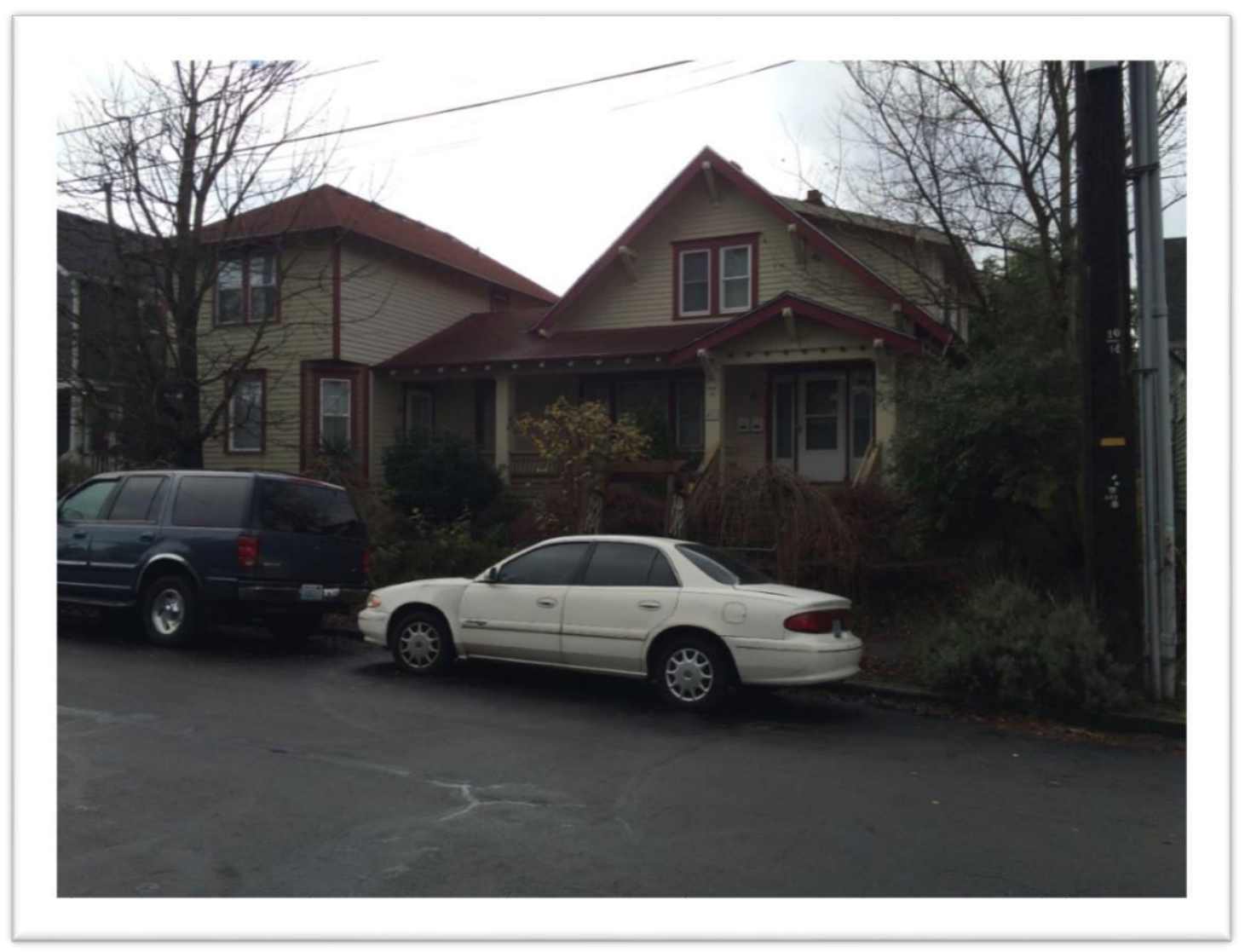

Figure 12 Charles and Sandy Moose's House Today - 422 NE Going. Photo by the author. In early 1995, the Portland Police Bureau partnered with five local banks to offer the "Police at Home" program. According to a PPB press release about the program, "Police at Home" was initiated by Mayor Katz and Chief Moose. ${ }^{567}$ The purpose of the program was simple: the program was designed "to encourage Portland police officers to purchase homes in targeted areas." 568 In this loan financing incentive, officers would

\footnotetext{
567 City of Portland Archives, B/030226, 24-02-15, Subject Files, Police: Mayor's Office, 1993-1996, Police Related Press Releases/Video Tapes, file "11/1994 - May 1995 News Releases," "Program Seeks To Encourage "Police At Home" In Selected Portland Neighborhoods," 2/6/1995.

${ }^{568}$ City of Portland Archives, B/030229, 24-03-36, Subject Files, Police: Mayor's Office, 1993-1998, Box 2, file "The Bulletin," "Special Supplement: Police at Home," The Bulletin, 2/11/1999.
} 
be able to get a home loan with no money down and pay no out of pocket closing costs. The officer would still need to qualify for the mortgage, and the costs would be rolled into the loan, but the upfront cash outlay was removed. ${ }^{569}$ Local banks that participated in the Police At Home program included Washington Mutual, Key Bank, US Bank of Oregon, Bank of America - Oregon, and First Interstate Bank. The banks agreed to waive some transaction fees and attempted to get other institutions to donate their services. ${ }^{570}$ The federal Community Reinvestment Act required banks to serve their communities, and the Portland program fell under these auspices. ${ }^{571}$ The Albina Rotary Club, after hearing Moose speak about moving to the King Neighborhood in 1993, also supported the proposal. ${ }^{572}$

The loan program was, as one might expect, very conditional. The officer would need to live in the home for five years. In addition, the home needed to be in one of eight targeted neighborhoods. In North/Northeast, the neighborhoods were: Kenton, CullyKillingsworth, Humbolt, Unthank Park/Boise, and an area along Martin Luther King Jr. Boulevard that was selected for renewal. In Southeast, the neighborhoods included Lents, Harney Park, and in Sunnyside, along SE Belmont Street. ${ }^{573}$ Acknowledging the

\footnotetext{
${ }^{569}$ Fentress, "Loan Plan Urges Officers To Live in Target Areas," B 01.

${ }^{570}$ Fentress, "Loan Plan Urges Officers To Live in Target Areas," B 01.

571 Fentress, "Loan Plan Urges Officers To Live in Target Areas," B 01.

572 City of Portland Archives, B/030226, 24-02-15, Subject Files, Police: Mayor's Office, 1993-1996, Police Related Press Releases/Video Tapes, file "11/1994 - May 1995 News Releases," "Program Seeks To Encourage "Police At Home" In Selected Portland Neighborhoods," 7/25/1994.

${ }^{573}$ Fentress, "Loan Plan Urges Officers To Live in Target Areas," B 01.
} 
risk of the selected neighborhoods, the officer needed to install and maintain a home alarm system in order to qualify for the program. ${ }^{574}$

Police at Home was, according to the bureau, "response to our community's desire to stabilize particular neighborhoods in need;" and it allowed for a touch of flexibility in its implementation. ${ }^{575}$ A 1999 fact sheet to officers explaining the program noted that PPB agreed to decide on "whether a property outside the target neighborhood boundaries of the program can still be considered eligible, with the spirit of the program and these neighborhood stabilization guidelines in mind." 576 There was a specific contact within the bureau to assist the officers, as well as the steps necessary to determine eligibility outside the target neighborhoods.

The Oregonian liked the proposal as well, saying "enticing officers to become residents won't solve all crime problems in Portland's neighborhoods. But it's a crime-prevention strategy worth trying." 577 The Oregonian editors added that, "We think as Meese, Moose and Katz do, that police living, shopping and socializing as neighbors with the people they're paid to protect would contribute more to this community's sense of

\footnotetext{
${ }^{574}$ City of Portland Archives, B/030229, 24-03-36, Subject Files, Police: Mayor's Office, 1993-1998, Box 2, file "The Bulletin," "Special Supplement: Police at Home," The Bulletin, 2/11/1999. It was also recorded that "neither the lending institution or the Bureau inspects properties for compliance with this requirement."

575 City of Portland Archives, B/030229, 24-03-36, Subject Files, Police: Mayor's Office, 1993-1998, Box 2, file "The Bulletin," "Special Supplement: Police at Home," The Bulletin, 2/11/1999.

${ }^{576}$ City of Portland Archives, B/030229, 24-03-36, Subject Files, Police: Mayor's Office, 1993-1998, Box 2, file "The Bulletin," "Special Supplement: Police at Home," The Bulletin, 2/11/1999.

577 Editorial, "Welcome Home, Officer," The Oregonian, 2/14/1995, B 04.
} 


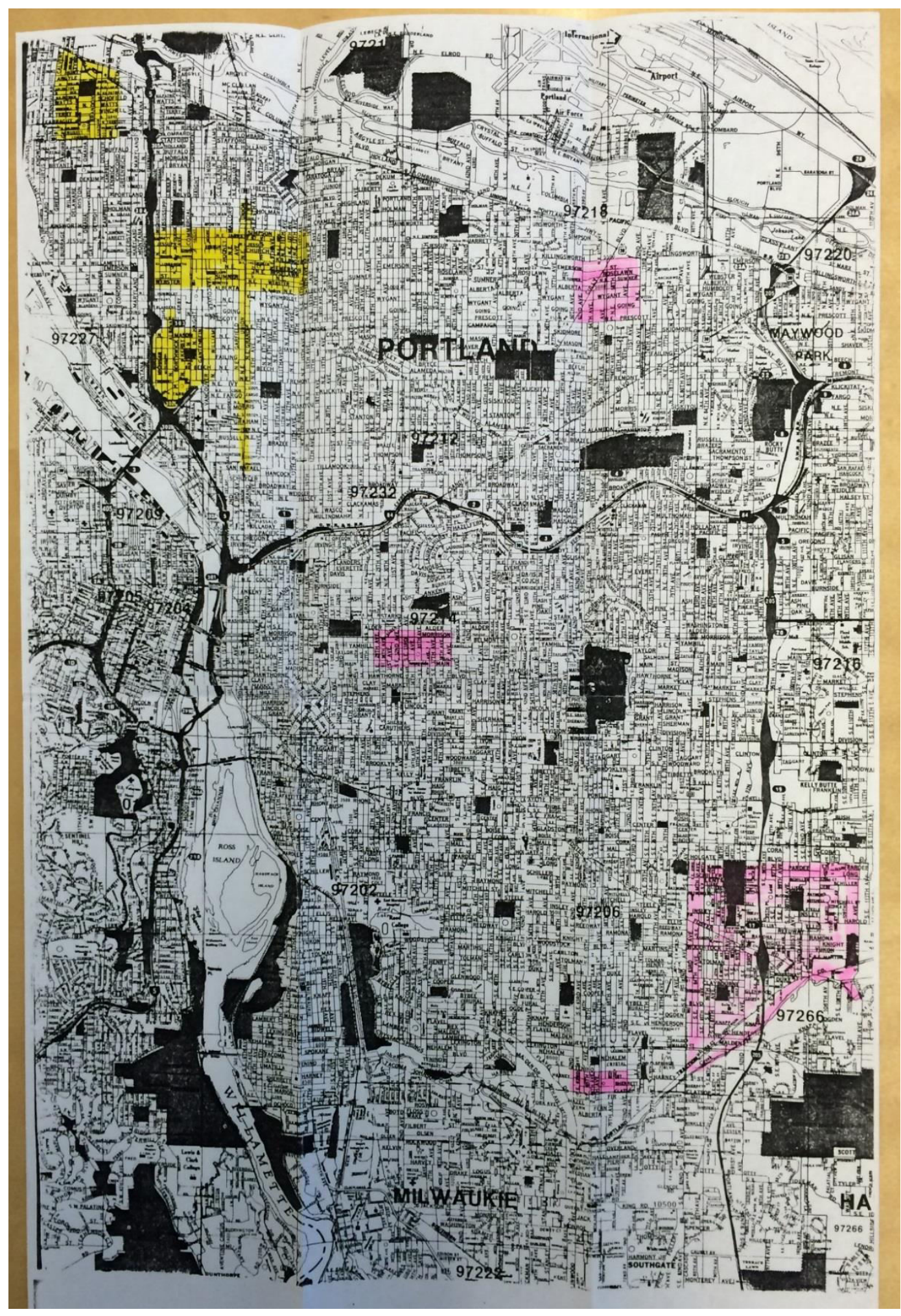

Figure 13 Police at Home Map. City of Portland Archives 
safety than would officers spending only their eight-hour shifts here and then commuting back to the suburbs."578

According to Portland Police Bureau data, crime fell by 13.4 percent the first three months of 1996. Chief Moose felt this was a vindication of his work. The chief said, "This decline reflects our continuing efforts as a community on prevention and partnership making your property more secure, and making your neighborhood a place where people work together, and with their police officers, to continually improve the quality of life." 579 Moose's program was to have officers in the neighborhood - not only as police men and women, but as professional role models. The officers would also assist in inspiring their neighbors to bring things up, and serving as role models for the neighborhood kids to look up to. As he stated, this is a cycle that does not stop - never ends, and connections need to be made with the children to sow the seeds and to continue this progression.

In an August 21, 1996 Heritage Foundation report, former Attorney General Edwin Meese III called for police departments, nationwide, to "anchor police in the community." ${ }^{580}$ It seemed that Portland was now a national leader in community policing.

\footnotetext{
578 Editorial, “Hometown Police," The Oregonian, 9/4/1996, E 08.

${ }^{579}$ Peter Farrell, "Portland Takes A Bite Out Of Crime, The Oregonian, 4/22/1996, B 02.

${ }^{580}$ Editorial, "Hometown Police," E 08.
} 
Not all of the rank and file were optimistic about the Police At Home loan program.

One Portland police officer said that his wife would not let him participate; she was afraid of living in a high crime neighborhood. ${ }^{581}$ Another officer who did purchase a home in one of the designated neighborhoods said the transition was not easy: some of her new neighbors were not only not welcoming, they were "downright hostile." 582 "It'll take time, more than the five years I expect to be here," she said, to change her neighbors' attitudes. ${ }^{583}$

"The only way you can turn that around is by moving in" -Charles Moose, November 1993.

In present day Portland, discussions of race in "America's whitest city" go hand in hand with the concern about gentrification, and the role that force has had in the process of "whitening" the city. It is an interesting exercise to consider Charles and Sandy Moose's role in this evolution of our urban environment.

Gentrification, and the societal implications of that process, were not unknown at the time of Moose's move. Dee Lane of The Oregonian provided a very succinct definition of the process in 1990. "Gentrification, they call it. People with money move in and fix up the neighborhood. Property values go up, but in the process low-income people are

\footnotetext{
581 Editorial, “Hometown Police," E 08.

582 Editorial, "Hometown Police," E 08.

583 Editorial, "Hometown Police," E 08.

585 Danks, "Moose Buys Into The Bid," A 01.
} 
pushed out of the community." 586 Other 1990s Portlanders were concerned about the issue as well. In Norm Maves Jr. \& Wade Nkrumah's 1994 Oregonian article, “Goin” North," the reporters wrote that "Steven Foust, the land-use coordinator of the King Neighborhood Association, sees it as the beginning of the 'cycle of gentrification of North Portland.' The neighborhood associations did all the dirty work, he says, and now people are moving in to reap the benefit." While these columnists do not use the specific words, race was absolutely a component of this "cycle of gentrification."

Charles Moose was an astute student of the condition of Portland's black neighborhoods, and their evolution during his years as a police officer in the city. In 1970s Portland, Moose said "There was a sense, at that time, in that city, that black people must want the environment they lived in - because they kept living there." 587 After years of implementing community policing strategies on the streets of North and Northeast Portland, Charles Moose had advanced his thoughts on these neighborhoods. Moose said in 1994 that he noticed that, "There are a lot of good people living in some of our troubled neighborhoods. We shouldn't turn our back on 'em. We should join 'em, and we can reclaim that neighborhood if enough of us move back into the neighborhood and be part of it." 588

\footnotetext{
${ }^{586}$ Dee Lane, “Neighborhood Activists Blame Blight On Lenders," The Oregonian, 9/11/1990, A 01.

${ }^{587}$ Moose and Fleming, Three Weeks In October, 17.

588 NBC News, "America Close Up," 6/2/1994.
} 
When Moose moved into the King neighborhood, the idea was to absolutely turn the neighborhood around and "bring it up." He wanted other police officers to move into the neighborhood after him, and he created incentive programs to facilitate this process. But Moose didn't want to stop there - he wanted to encourage business owners to invest in these "blighted" neighborhoods. He wanted infrastructure created, and good paying jobs for the residents. Moose's community policing was not only the lowering the threat of crime, but also lifting up the economic well-being of his neighbors.

Chief Moose was unabashed in his boosterism of Northeast Portland. At his August of 1993 City Club of Portland address Chief Moose said, "So I would encourage people individually to use our entire city. To look for opportunities to use those areas that are underutilized. For our business people to recognize that the last, great business opportunity is in Northeast Portland! That there's land there, that there are services there, there are roads there, there are sewers there; but we're not putting our businesses there. In fact, we're pulling out. And I guess I would urge individuals to look around and see those opportunities and use those areas." 589

Business owners were receptive to Moose's suggestions, but the reality of a crimefilled North and Northeast Portland often dampened enthusiasm. About nine months after his City Club speech, Tim Rich and Julia Spence of Neil Kelly wrote to Chief Moose

589 City Club of Portland, “New Directions For Portland's Police Department." 8/6/1993. https://www.youtube.com/watch?v=eP1UXxiVBqo\&feature=youtu.be 
about a June 16, 1994 drive-by shooting that happened on their businesses' corner of North Alberta and Albina at 3:00 in the afternoon. ${ }^{590}$ Concerned about their employees, their neighbors, and their community, they laid out all that the company had done to support youth groups and nearby schools in the neighborhood, and their desire to participate in the Neighborhood Watch program. They summed up their frustration with the situation by writing that "with the seriousness of the problems facing our city, and this neighborhood in particular, we need to know that the City is doing all it can." 591

The chief responded with a positive message and commended Neil Kelly on their involvement in "numerous public safety efforts... These efforts make community policing a reality." 592 Moose also wrote that the Portland Police Bureau was "trying many public safety and economic development strategies to address these problems." 593 He concluded the message by stating, "Remember, by working together we can make a difference."

The police bureau was crafting a mandate to actively improve the economic wellbeing of the citizens of these neighborhoods. Again, on the face of it, this seems like an unusual initiative for a law enforcement organization to undertake. This is a far cry from

\footnotetext{
${ }^{590}$ City of Portland Archives, A2005-004, 0252-01, Mayor Vera Katz Subject Files, Internal Staff Files: Chuck Bolger, 1998-1999, Box 2, file "Constituent letters to Chief of Police Charles Moose," letter from Tim Rich and Julia Spence of Neil Kelly, 6/23/1994.

${ }^{591}$ City of Portland Archives, letter from Tim Rich and Julia Spence of Neil Kelly, 6/23/1994.

592 City of Portland Archives, A2005-004, 0252-01, Mayor Vera Katz Subject Files, Internal Staff Files: Chuck Bolger, 1998-1999, Box 2, file “Constituent letters to Chief of Police Charles Moose," letter from Chief Moose to Tim Rich and Julia Spence of Neil Kelly, 7/7/1994.

${ }^{593}$ City of Portland Archives, letter from Chief Moose to Tim Rich and Julia Spence of Neil Kelly, 7/7/1994.
} 
apprehending criminals, handcuffing them, and taking them in a police cruiser, sirens blaring, to the Multnomah County jail. But this is exactly what Chief Moose was advocating for his bureau to do. In a 1994 letter to Denny West, Director of the Housing Authority of Portland (responsible for administering Iris Court), Chief Moose wrote that "It is our intent to be an active partner with you in the Family Investment Center. We know from experience that healthy communities are communities where there is opportunity. For many people, that means jobs." 594

A year later, Moose was again trumpeting continued economic development in his targeted communities. On May 6, 1995, Chief Moose led a five mile walk through various neighborhoods in Northeast Portland called the "Walk For Humanity." The walk was a fundraiser for Habitat For Humanity, which had been building homes in these neighborhoods since 1981. In 1995, plans were underway to build seven houses. Moose said that, "the Walk for Humanity builds pride and fosters hope in our neighborhoods. As a resident of Northeast Portland, I have seen firsthand the improvements that the many community groups have made in my neighborhood. The Walk showcases these achievements for all to see and celebrate." 595

\footnotetext{
${ }^{594}$ City of Portland Archives, A2005-004, 0252-01, Mayor Vera Katz Subject Files, Internal Staff Files: Chuck Bolger, 1998-1999, Box 2, file “Constituent letters to Chief of Police Charles Moose," letter from Chief Moose to Denny West, Housing Authority of Portland, 7/20/1994.

595 City of Portland Archives, B/030226, 24-02-15, Subject Files, Police: Mayor's Office, 1993-1996, Police Related Press Releases/Video Tapes, file "11/1994 - May 1995 News Releases," "Chief Moose Leads Northeast Portland In Walk For Humanity," 5/5/1995.
} 
At his final City Club of Portland speech in July of 1999, Moose expounded on his theories of law enforcement and economic development. He said that, "The state of the Portland Police Bureau is interwoven with the state of the city, with the state of each neighborhood, with the state of each man, woman and child. The Police Bureau can solve problems, but the safety and well-being of our community are based on a holistic approach by the people that live, work and visit the city of Portland."596

Moose was unapologetic about the gentrifying that had taken place during his tenure. At the same City Club of Portland address, Moose told the attendees that, "I find it quite fascinating now that the issue most often talked about in the King Neighborhood is gentrification. We're not talking about homicide, we're not talking about gang activity, people are talking about things are going too well. People are moving in. Now, I understand all of the issues and the ramifications to gentrification, and I want to be respectful in regards to that. But in terms of talking about crime, the Mayor and I would much rather talk about gentrification than shots fired, or drive-by shootings." 597

Some may interpret his observations at that last City Club meeting, just before he accepted his new position in Montgomery County, Maryland, as a "mission accomplished" type of presentation. "Let's assure that our deployment changes match community changes. If indeed the main issue in the King Neighborhood is gentrification,

\footnotetext{
${ }^{596}$ Maxine Bernstein, “Outgoing Chief Urges Everyone to Take Part," The Oregonian, 7/24/1999, D 01.

${ }^{597}$ City Club of Portland, "The State of Portland Police." 7/23/1999. https://www.youtube.com/watch?v=SXLLTs81WPE\&feature=youtu.be
} 
then maybe we need some of the police officers in the Northeast precinct to go to East precinct where there are far more people willing to shoot community members and police officers."598 Moose felt that he had indeed "turned the neighborhood around," and that it was time to start focusing on other sections of Portland and expand his program of economic development and gentrification.

The cycle of gentrification continued, and some could argue that Moose's example, and his strategic policies of placing officers in those targeted neighborhoods, was an integral component of that development. In a February 1999 review of the Police at Home program for The Bulletin, Chief Moose stated that between 1995 and 1997, twenty-two officers bought homes through the program. ${ }^{599}$ This was exactly his objective. Moose had told The New York Times shortly after he moved in that, "one of my goals is to show other officers that we could live here and nothing would happen to Sandy and I." 600 Little did the chief know that the consequences of one summer beach party would unravel all that he had worked for and make him question his family's safety in their King neighborhood home, and indeed, his commitment to the community that he served.

\footnotetext{
598 City Club of Portland, "The State of Portland Police." 7/23/1999.

${ }^{599}$ City of Portland Archives, B/030229, 24-03-36, Subject Files, Police: Mayor's Office, 1993-1998, Box 2, file "The Bulletin," "Special Supplement: Police at Home," The Bulletin, 2/11/1999.

600 Timothy Egan, "To Stay in Touch With Crime, A Police Chief Moves Near It," The New York Times, 12/25/1993, Sec. 1, 6.
} 


\section{Chapter 6 - Birthday Parties and Bean Bags}

"If there needs to be an unemotional, milquetoast chief, it's not going to be me."601 -Charles Moose

It all started in a pretty typical manner for a hot August weekend in 1998. Some young people wanted to have a beach party. What transpired would result in an emotional outburst that left the black community, and many of the other citizens of Portland, reeling - and a dedicated, motivated police chief questioning his commitment to community policing, and indeed, his commitment to the citizens of the City of Roses.

Daniel Binns, a neighborhood entrepreneur, recording artist, and event promoter, hosted an annual birthday party. ${ }^{602}$ Typically scheduled to coincide with the "Low Rider Magazine Car Show" at the Expo Center in North Portland, the party was conducted on the Columbia River at Broughton Beach (also known as Ditlers). The parties tended to end a bit after sunset, and then the low riders and party goers moved onto business and parking lots in the NE Martin Luther King Jr. Blvd. (MLK) vicinity. Binns's 1996 soiree drew 1,000 to 1,500 attendees. ${ }^{603}$ The 2,800 guests to his 1997 bash enjoyed a large

\footnotetext{
${ }^{601}$ Editorial, “Chief Was Never Milquetoast," The Oregonian, 5/28/1999, D 14.

602 Lisa Loving, "A Forgotten Riot That Rocked City Hall," The Skanner, 8/22/2014. Accessed online 5/25/2016 http://www.theskanner.com/news/northwest/21739-the-skanner-news-archives-a-forgottenriot-that-rocked-city-hall Loving also calls Binns "charismatic and popular... and [an] all around well-loved guy."

${ }^{603}$ Commander Derrick Foxworth, "After Action Report - Daniel Binns Annual Birthday Party, Northeast Precinct Planning and Response," Bureau of Police, Inter-Office Memorandum, 9/29/1998. Pg. 2. Lisa Loving Collection. Note on source: The researcher tried to obtain a copy of the "Binns Report" from the Portland Police Bureau. That request was denied, and a very brief summary of said report was issued instead. After speaking with longtime Skanner reporter Lisa Loving, she stated that she had a copy of the
} 
stage on the beach, with "rappers, a weight lifting competition, music and bikini girls."

Food was, according to the flyer, " donated by Popeyes Chicken." 604

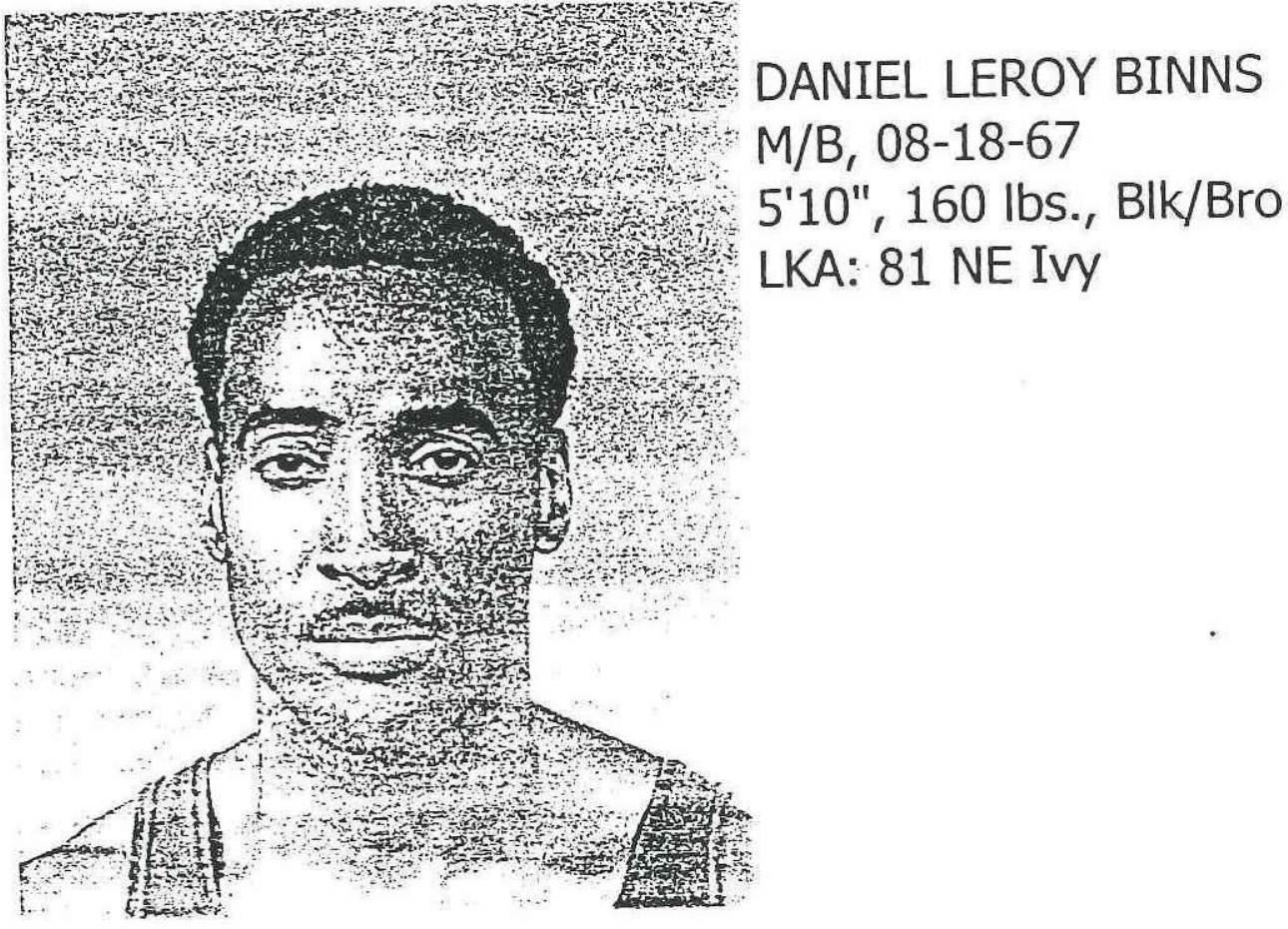

Figure 14 Daniel Binns. Lisa Loving Collection.

Binns's Birthday Bashes were legendary in the community, but the Portland Police

Bureau did not share the same enthusiasm about the annual events. The parties were

report, and would loan it for use in this essay. Press accounts from the City Council presentation of the report detail five black binders of over 900 pages. Loving loaned a single binder, of several hundred pages to this writer which she called "the Binns Report." It does indeed appear to be authentic, but it may also be incomplete, as it appears to not be near 900 pages. On 2/4/2016, this researcher had occasion to show the Loving binder to former PPB Chief Derrick Foxworth (who also authored several of the reports in the binder). Foxworth could not recall if this was the entire Binns report, but he did assert that the Loving binder was at minimum authentic photocopies of main sections of the report presented to the Council. ${ }^{604}$ Commander Orr, "Operations Order: Party at Ditlers Beach (Broughten Beach) $43^{\text {rd }}$ and Marine Drive 081797 Sunday 1300-2100," Bureau of Police, Inter-Office Memorandum, 8/15/1997. Pg. 1. Lisa Loving Collection. For number of attendees, see Capt. Ratcliff, "Binns party scheduled for August 16 $6^{\text {th }}$," Bureau of Police, Inter-Office Memorandum, 7/29/1998. Pg. 1. Lisa Loving Collection. 
also dangerous gatherings. Shots were fired at his 1996 party; and his 1997 party

resulted in a shooting, with party goer Larry Watkins shot in the mouth. ${ }^{605} \operatorname{In} 1997$

several people drew guns and pointed them at the crowd, with "hundreds of people

running" away, trying to not get shot. Needless to say, the bureau was reluctant to have another firearm incident on their hands. ${ }^{606}$

Some residents and police officers claimed that Binns was a gang member, although there was some debate about Binns's gang involvement. Vanessa Crawford was a friend of Binns. She related to reporters that Binns was not a member of a gang. "That gangster stuff is hockey puck," she said. ${ }^{607}$ Binns did have a criminal past, having been arrested for fourth degree assault, concealed weapons charges, cocaine possession, and probation violations, although he had not been arrested since $1990 .{ }^{608}$ His parties did appear to draw gang members. His 1996 event was comprised of "20 percent gang members," according to the PPB. ${ }^{609}$ A police report on the 1997 party said that "large

\footnotetext{
${ }^{605}$ Foxworth, "After Action Report - Daniel Binns Annual Birthday Party," Pg. 4. Lisa Loving Collection. PPB officers stated that Watkins was a gang member. Watkins, who had HUSTLER tattooed across his chest, denied this affiliation. He seems to have had bad luck at least, for he had been shot in the arm the week prior to the party. Commander Derrick Foxworth, "After Action Report - Daniel Binns Annual Birthday Party, Northeast Precinct Planning and Response," Bureau of Police, Inter-Office Memorandum, 9/29/1998. Pg. 4. Lisa Loving Collection.

606 Peter Farrell \& Laura Trujillo, "Meeting May Calm Protest Over Police Action At Party," The Oregonian, 8/19/1998, A 01.

${ }^{607}$ Farrell \& Trujillo, "Meeting May Calm Protest," A 01.

${ }^{608}$ Farrell \& Trujillo, "Meeting May Calm Protest," A 01.

${ }^{609}$ Foxworth, "After Action Report - Daniel Binns Annual Birthday Party,” Pg. 3. Lisa Loving Collection.
} 
numbers of gang members have attended this event in the past." 610 If Binns himself was not a gangster, then at least attendees of his parties were.

Some of Binns's friends painted a very different picture of the man than the police relayed. Melissa Pittman said that Binns "did a lot despite what all the rumors were about him. I don't see that side of him. What I see is the person who would do anything for children." 613 Pittman called Binns a "role model" who loved children and focused his attention onto his community. He supported neighborhood basketball tournaments and other events. ${ }^{614}$

In July of 1998, Portland police spotted a flyer that said "On and Cracking Again! $4^{\text {th }}$ Annual Beach Bash \& BBQ." 615 The flyer declared that the party was planned for Southeast Portland's Sellwood Park that year. Pre and post party events would be featured in the Northeast part of town.

On Sunday, August 16, 1998, the police closed Sellwood Park (SE $7^{\text {th }}$ Ave. \& Miller St.) on the grounds that many of the 2,000 guests expected had gang associations. ${ }^{616}$ Many of the people who had planned on attending the Sellwood affair then ventured to Irving Park (NE $7^{\text {th }}$ Ave. \& Fremont St.) to have a substitute party. Unfortunately, there was a previously scheduled basketball tournament already at that location. This permitted

\footnotetext{
610 Orr, “Operations Order: Party at Ditlers Beach,” Pg. 1. Lisa Loving Collection.

613 David Austin, “Man Who Led Protest In 1998 Is Found Shot,” The Oregonian, 12/15/2003, B 07.

614 Austin, "Man Who Led Protest In 1998," B 07.

${ }^{615}$ Foxworth, "After Action Report - Daniel Binns Annual Birthday Party," Pg. 4. Lisa Loving Collection.

${ }^{616}$ Farrell \& Trujillo, "Meeting May Calm Protest," A 01.
} 
event had a few hundred attendees already, so when Binns's partygoers arrived, there was a mass of humanity, and confusion.

The Portland Mounted Patrol was then called in to clear Irving Park, and they appeared as a visible, commanding force. ${ }^{617}$ The police presence at the park made many draw comparisons to a war zone (apparently a common metaphor for 1990's Portland). State Representative Jo Ann Bowman, who lived near the park and saw the police presence, remarked that, "I really thought we were under siege." ${ }^{618}$ The police maintained that Binns did not have a permit for the parks, nor security or insurance for a party. They were afraid that the bash could get out of control. Lt. Cliff Madison, acting information officer for the bureau said, "We have too many families and kids there to have them in the middle of this party with no security." 619

Chief Moose and Derrick Foxworth both met and spoke with Binns about the closure of the party at different points on Sunday night. ${ }^{620}$ According to Lt. Madison, the chief's "initial thoughts were that Danny (Binns) was going to go home that evening, and everything would be peaceful and calm."621 Binns had earlier told Foxworth that since

\footnotetext{
${ }^{617}$ Farrell \& Trujillo, "Meeting May Calm Protest," A 01.

618 Tonya Y. Parker, "Melee is Focus of Meeting," The Portland Skanner, 8/19/1998, 1.

${ }^{619}$ Farrell \& Trujillo, "Meeting May Calm Protest," A 01.

620 Peter Farrell \& Laura Trujillo, "Protest Brings Differing Accounts," The Oregonian, 8/19/1998, A 01.

${ }^{621}$ Farrell and Trujillo, "Protest Brings Differing Accounts," A 01.
} 
the party was canceled, he and a few ladies were going to go to the beach for the day. ${ }^{622}$

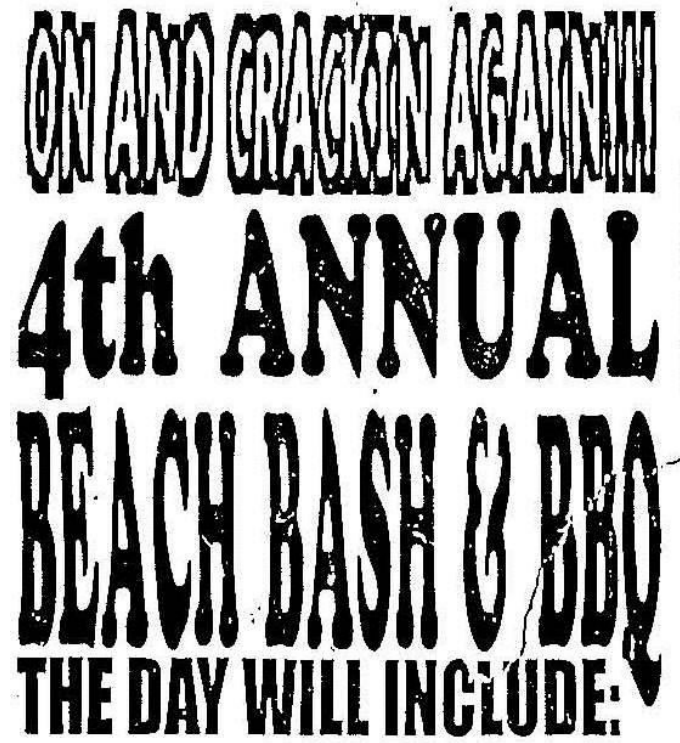

BIKINI CONTEST

BUMP SHAKER CONTEST

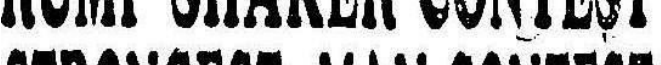
STRONGEST" MAN CONTEST DANCE CONTEST

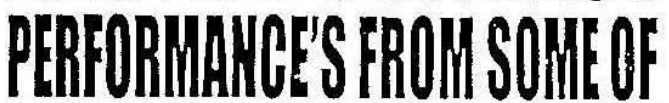
PORTLAND'SFNEST SUN, AUG goth

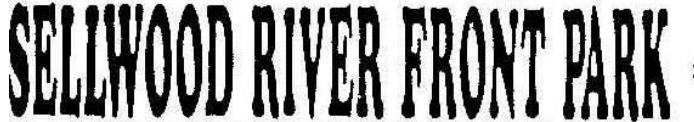
[NEKT TO OAKS PARK] IPM til 8:30PM
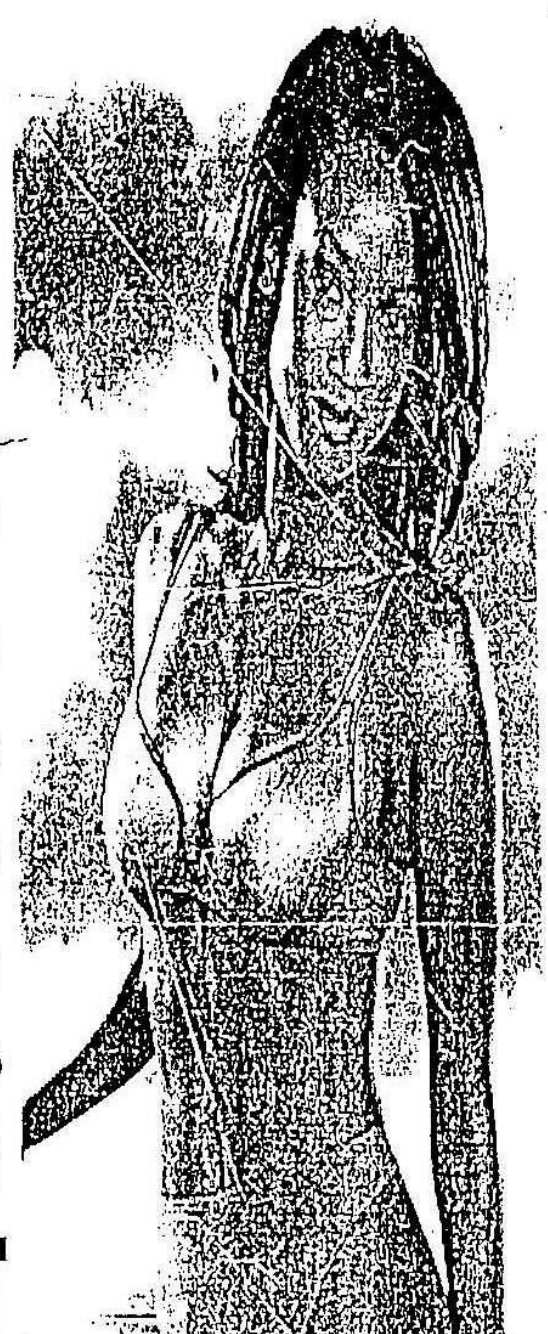
The police felt somewhat deceived by Binns about his intentions. When the basketball tournament ended at 10 p.m., and as those attendees left, the police closed Irving Park, and deployed several barricades on MLK to help control the traffic. The department also placed barricades on NE Fargo, Ainsworth, and Alberta streets, with more roving police patrols up and down MLK Jr. Blvd. ${ }^{623}$ The police presence was overt.

Binns's party goers felt harassed by the police. As Demetreas Wattier, a Portland State University student said, "It seems like every time we try to do something, they are always pushing it down." 624 Binns's nephew, Marshall Richmond, felt that black events were being treated differently than white events in Portland. "Whites have the beer fest and The Bite, even the carnival [Rose Festival Fun Center] comes once a year. Every event that comes to Oregon isn't perfect. Somebody's going to get pushed or shoved, like at the carnival there was a shooting." ${ }^{25}$ Vanessa Crawford also condemned the media for contributing to the situation: "When they see a black person trying to do something, they always try to down the black person. When whites are involved in crimes... there's not that much publicity." ${ }^{626}$ Many agreed that they were fed up from what they perceived to be the police's "excessive, unfair treatment" in the weeks leading up to the party. ${ }^{627}$

\footnotetext{
${ }^{623}$ Foxworth, "After Action Report - Daniel Binns Annual Birthday Party,"Pg. 11. Lisa Loving Collection. 624 Peter Farrell, “Police Disperse Protesters on MLK," The Oregonian, 8/18/1998, B 07.

${ }^{625}$ Farrell \& Trujillo, "Meeting May Calm Protest," A 01.

${ }^{626}$ Farrell \& Trujillo, "Meeting May Calm Protest," A 01.

${ }^{627}$ Parker, "Melee is Focus of Meeting," 1.
} 
"There is a long history of tension about the proper role of the police in this community, and I believe Chief Moose has made strides in this area." 628

- City Commissioner Erik Sten, 1998

By Monday, August 17, 1998, an irate group of Northeast Portland residents were directing their anger at the Portland Police Bureau, and they were upset about the perceived inequity in how the Binns party was handled. Assembling in the Popeye's Chicken fast food restaurant at N.E. MLK Jr. Blvd. and Fargo Street, a small group, including Daniel Binns, started walking in a lane of traffic, heading north up the major thoroughfare. ${ }^{629}$

As the group progressed, they gathered more marchers and ended up at the Northeast Precinct of the Portland Police Bureau. Estimates of group size at this point ranged from fifty to 100 marchers, as well as "many cars. ${ }^{630}$ Some of the marchers later said they had gone to the Northeast Precinct to file a formal complaint. ${ }^{631}$ Lieutenant Madison said later that he could not find any record of anyone trying to file a complaint. ${ }^{632}$ Staff inside the precinct building locked all of the doors and denied access to the protestors. Undeterred, they turned south and started marching down MLK. More marchers joined as they continued.

\footnotetext{
${ }^{628}$ City of Portland Archives, Official Minutes, City of Portland Council Meeting, 11/18/1998, 11.

${ }^{629}$ Foxworth, "After Action Report - Daniel Binns Annual Birthday Party," Pg. 13. Lisa Loving Collection.

${ }^{630}$ Foxworth, "After Action Report - Daniel Binns Annual Birthday Party," Pg. 13. Lisa Loving Collection.

${ }^{631}$ Farrell, "Police Disperse Protesters," B 07.

632 Farrell \& Trujillo, "Meeting May Calm Protest," A 01.
} 
As the protestors headed down MLK, several signs were displayed that said "Give Us Back Our Rights," and "We're Not All Gang Members." 633 Perhaps as many as 200 protestors marched about a quarter of a mile, on to Northeast Martin Luther King Jr. Blvd and Going Street, near to where Moose lived, with their grievances. ${ }^{634}$ Some in the crowd threw bottles and rocks. People were angry. ${ }^{635}$ Police gathered in the intersections at the ends of the street. Commander Derrick Foxworth was present, supported by up to forty armed, helmeted officers. ${ }^{636}$ Protestors stood outside of the chief's home and yelled and chanted "We want Moose! We want Moose!"637 The protestors yelled racial slurs and vulgar words. ${ }^{638}$ The Portland Skanner may have summed the situation up best when reporter Tonya Parker described it as "a melee of sorts near Portland Police Chief Charles Moose's home."639

The PPB After Action report is very detailed, and lays much of the responsibility for rousing the crowd on Daniel Binns. Officer John Scruggs noted that Binns led the crowd in chants and yelled at the protesters: "Where's the black fucking chief?" "Where's the black fucking Foxworth?" "Fuck them!" "I'm going to be mayor!" "Fuck the chief!" Binns

\footnotetext{
633 Parker, "Melee is Focus of Meeting," 3.

${ }^{634}$ Farrell and Trujillo, "Protest Brings Differing Accounts," A 01. The account also says "Throughout the evening, the crowd grew to 100 or 150 people."

635 Farrell and Trujillo, "Protest Brings Differing Accounts," A 01.

${ }^{636}$ Farrell, "Police Disperse Protesters," B 07.

${ }^{637}$ Maxine Bernstein, "Moose Lashes Out At Beanbag Critics," The Oregonian, 11/19/1998, A 01.

${ }^{638}$ Bernstein, "Moose Lashes Out," A 01.

${ }^{639}$ Parker, "Melee is Focus of Meeting," 1.
} 
then stepped onto Moose's yard and led the crowd in more chants, and then told them to come closer. ${ }^{643}$

This was the other side of community policing. Moose had maintained that he was injecting himself into the community. He had established his home as a safe gathering area for the children of the neighborhood waiting for the bus, and wanted his home to be a refuge after school as a block house. Moose had declared his home to be an iconic center for community policing, a resource for the neighborhood. His house was a physical extension of this visible, public face in the community. In Binns's protest, Moose's constituents' shifted the paradigm that he had created. They were seeking to reach out to the power structure that policed them, and they had the courage to go right to the head. Moose had asked for this transparency, this feedback from the community. This is where people could come to the chief - to see Mr. Moose, their community chief.

Some reported that Moose was not home during the protest. ${ }^{644}$ Madison maintained that the chief stayed in his home during the event. Madison added, "If someone wants to meet with the chief, we can set it up. But he can't outshout the crowd. And we thought it might be inciteful for him to come out." 645

\footnotetext{
${ }^{643}$ Foxworth, "After Action Report - Daniel Binns Annual Birthday Party," Pg. 15. Lisa Loving Collection. ${ }^{644}$ Farrell, "Police Disperse Protesters," B 07.

${ }^{645}$ Farrell and Trujillo, "Protest Brings Differing Accounts," A 01.
} 
Commander Foxworth seems to have been understanding and even accommodating throughout much of the event, but he was concerned about the whole of the community that he was attempting to protect. "They had the lawful right to demonstrate and get their message across," Foxworth said, but, "we had reports of people using profanities and making remarks that could have been perceived as threatening" to the chief. ${ }^{646}$ One of the party organizers, James Mathis, disagreed. "We never infringed upon Chief Moose's property. All we did was chant." 647 Despite his assertion, Foxworth's after-action report maintained that Binns was on Moose's lawn.

Foxworth was, of course, well-experienced with civil disobedience and large groups of protestors. He was even knowledgeable about when those groups turned to riots, for he had witnessed the X-Ray Café Anarchist Riot. Foxworth had been on the scene there, speaking to those anarchist protestors through a bullhorn. This was nothing new to him; although on this occasion, the protest was occurring on his boss's doorstep and the marchers were threatening his safety. Furthermore, Foxworth knew Binns and understood how angry he was. As he examined his thinking in his after action report, Foxworth wrote that "there was a concern that this anger would be channeled into other participants involved in the protest, which it obviously had." He added that he

\footnotetext{
${ }^{646}$ Parker, "Melee is Focus of Meeting," 3.

${ }^{647}$ Parker, "Melee is Focus of Meeting," 3.
} 
feared that "this anger and unwillingness to abide by the law would erupt into civil disorder, violence and other criminal behavior." ${ }^{648}$

Foxworth wrote: "I knew from my experience of over 16 years as a police officer, serving in a variety of assignments, and being involved in managing and responding to many crowd situations involving demonstrators, that most demonstrations have designated leaders, monitors or marshals who police could often negotiate with and reach agreement on the actions of the crowd and police. Binns had previously been in contact with myself and others but he was apparently unwilling to take on this role." ${ }^{649}$

Foxworth reported that he had walked toward the crowd and stood in the intersection of NE MLK Jr and Going. With a bullhorn, he told the protestors that they should leave the area. ${ }^{650} \mathrm{He}$ recalled that he said: "This is Commander Derrick Foxworth of the Portland Police Bureau's Northeast Precinct. I am declaring this an unlawful assembly. You have fifteen minutes to leave the area. If you fail to leave the area, you are subject to being arrested. If you wish to leave the area you can do so by going eastbound on Going Street to Grand Avenue." ${ }^{\prime 651}$

A man named Travis West had been in the crowd. After Foxworth ordered the dispersal, some of the protestors, including West, started heading south down MLK,

\footnotetext{
${ }^{648}$ Foxworth, "After Action Report - Daniel Binns Annual Birthday Party,” Pg. 15. Lisa Loving Collection. ${ }^{649}$ Foxworth, "After Action Report - Daniel Binns Annual Birthday Party," Pg. 16. Lisa Loving Collection. The author finds this "unwillingness to lead" particularly ironic after Binns was asserted to have yelled, "I'm going to be mayor!"

${ }^{650}$ Farrell and Trujillo, "Protest Brings Differing Accounts," A 01.

${ }^{651}$ Foxworth, "After Action Report - Daniel Binns Annual Birthday Party," Pgs. 17-18. Lisa Loving Collection.
} 
rather than walking east along Going Street, as Foxworth claimed he had ordered. ${ }^{652}$ As he walked, West said he saw helmeted officers with raised firearms, "as if it was a firing squad." ${ }^{653}$ The crowd was yelling at the officers, "We don't want you here," "go back to Beaverton!" and "you can't tell us we can't walk down this street!"654 Sgt. Hoerauf, positioned at Prescott Street, used a patrol car's public address system to tell the crowd to proceed back to Going Street. When the crowd refused to do so, officers fired four "beanbags" into the crowd. West was 50 yards away from the officers when he was hit, along with another man in the crowd. A total of six beanbag rounds were fired into the crowd. ${ }^{655}$

The aftermath of the melee found three men shot (albeit with a non-lethal weapon) and an angry dozen protestors arrested by police. Daniel Binns was in the number and accused of "riot."659 Michael Fesser was also arrested for perhaps the most serious crime of the day when he was charged with attempted first degree assault for swerving his rented Ford Taurus at an officer he had verbally threatened. ${ }^{660}$ Binns was arraigned,

\footnotetext{
652 Farrell and Trujillo, "Protest Brings Differing Accounts," A 01.

653 Farrell \& Trujillo, "Meeting May Calm Protest," A 01.

654 Foxworth, "After Action Report - Daniel Binns Annual Birthday Party,” Pg. 18. Lisa Loving Collection.

655 Maxine Bernstein, "Report Due Today On Police Use Of Less-Lethal Guns Against Crowd," The Oregonian, 11/18/1998, B 05. Beanbag guns shoot a nylon beanbag filled with lead shot at a speed of 120 $\mathrm{mph}$ (or to use a popular in the press metaphor for comparison's sake, "about as fast as a baseball line drive") and strikes with 153 foot-ponds of force. Police consider the beanbag "less than lethal," and bruises or "similar injuries" are the most common effect. See also John Painter JR., "Vancouver Police Try Beanbag Guns," The Oregonian, 11/24/1998, B 02.

659 Farrell \& Trujillo, "Meeting May Calm Protest," A 01.

${ }^{660}$ Farrell \& Trujillo, “Meeting May Calm Protest," A 01.
} 
and the terms of his arraignment included an order to stay four blocks away from Moose's home (Binns lived five blocks away). ${ }^{661}$

As the initial rage from the marchers subsided, both sides in the confrontation reflected on the incident. The protestors maintained that the march was not about the shutdown of Binns's party. They alleged that the protest was to draw attention to "a pattern of police harassment of Portland's African American population." ${ }^{662}$ During discussions, it became clear to them that "the overall issue of racism in society and how that translates into treatment by police and media" was a major concern. ${ }^{663}$

Foxworth agreed with some of the protestors' claims. He felt that there were not enough recreational activities for young adults in the summer in Portland. He also felt that not everyone attending functions like the Binns beach party were gangsters. ${ }^{664}$ Nonetheless, he had found himself in the awkward position of having to protect the chief's home and then fire upon the protestors.

On August 20, representatives of the African American community of North and Northeast Portland met with Derrick Foxworth. It was a high profile event, with participants pledging to increase communication and bring about a more peaceful

\footnotetext{
${ }^{661}$ Farrell \& Trujillo, “Meeting May Calm Protest," A 01.

662 Farrell \& Trujillo, "Meeting May Calm Protest," A 01.

${ }^{663}$ Foxworth, "After Action Report - Daniel Binns Annual Birthday Party," Pg. 22. Lisa Loving Collection.

664 Parker, "Melee is Focus of Meeting," 3.
} 
future and mutual respect." ${ }^{665}$ Daniel Binns and Mayor Vera Katz greeted one another and hugged.

The meeting was, by the accounts of Peter Farrell, an Oregonian reporter, largely devoid of the "hard issues that had surfaced during Monday's protest." ${ }^{666}$ Police overreaction and gang association were two terms specifically not addressed. Some in the community had been quite angered by the police demonstration of force. Jordana Sardo, in her letter to the editor of the Portland Skanner, wrote that the response against the "protestors condemning harassment" seemed like a "re-enactment of the civil rights struggles in the South." ${ }^{\prime 667}$

In his regular column in the Bureau's newsletter, The Bulletin, Chief Moose was quite complimentary to his officers. Moose acknowledged that the officers were "faced with some very challenging crowd control issues. ${ }^{\prime 668}$ Showing a little disappointment that "we were not able to keep the situation from becoming a media event," he found all of the officers' performance to be "exceptional," and felt that all involved "exercised patience, compassion and understanding." This was quite a different interpretation and analysis of the event than that offered by critics of the police. ${ }^{.69}$ Examining the use of teamwork in the response to the incident, Moose drew allusions to dignitary protection,

\footnotetext{
665 Peter Farrell, “Assessment Emerges Of Chance For Healing In Conflict's Aftermath," The Oregonian, 8/21/1998, B 01.

666 Farrell, "Assessment Emerges," B 01.

667 Jordana Sardo, "Letters To The Editor," The Portland Skanner, 9/2/1998, 4.

668 City of Portland Archives, B/030229, 24-03-36, Subject Files, Police: Mayor's Office, 1993-1998, Box 2, file "The Bulletin," "Chief's Corner," The Bulletin, 8/27/1998.

${ }^{669}$ City of Portland Archives, "Chief's Corner," 8/27/1998.
} 
but noted that the "energy, anger and mobility of these crowds made the need for discipline even more difficult and challenging." "But yet," Moose said, "everyone rose to the occasion. Again, well done." ${ }^{\prime 670}$

Moose finished his brief, internal note on the incident by closing with, "on a more personal note, it sure felt good when squads started to arrive at my home. There are no additional words needed." ${ }^{\prime 671}$ But not everyone agreed that the police had performed exceptionally well in responding to Daniel Binns's party and protest march. And, a seed had been sown that would make Charles Moose question his commitment to the Northeast community.

${ }^{670}$ City of Portland Archives, "Chief's Corner," 8/27/1998.

${ }^{671}$ City of Portland Archives, "Chief's Corner," 8/27/1998. 


\section{Chapter 7 - The Binns Report, the NOBLE Conference, and Departure}

"He made most everybody uncomfortable on occasion." 672

-The Oregonian, May 28, 1999

On Wednesday, November 18, 1998, Moose presented the police report on the Daniel Binns Birthday Party incident to the City Council. ${ }^{673}$ In the official minutes of the council meeting for the day, the chronicler noted that Mayor Katz said that the presentation by Moose "resulted from a rather unusual request by the police chief to return to council to discuss the findings and review procedures on this particular case." 674

The report was wheeled in to the council by Assistant Chief Bruce Prunk. It was over 900 pages, presented in five black binders. Every commander and officer associated with the demonstration were represented in one manner or another in those pages. There were photographs, officer's reports, details of police policies for deploying beanbag weapons, and so on. ${ }^{675}$ But rather than spending the council's time discussing

\footnotetext{
672 Editorial, “Chief Was Never Milquetoast," The Oregonian, 5/28/1999, D 14.

673 Maxine Bernstein, "Moose Lashes Out At Beanbag Critics," The Oregonian, 11/19/1998, A 01.

${ }^{674}$ City of Portland Archives, Official Minutes, City of Portland Council Meeting, 11/18/1998, 7.

675 Bernstein, "Moose Lashes Out," A 01.
} 
the contents of the report, Moose vented his "frustration about the report and his disgust at having protestors march to his home that night." ${ }^{\prime 676}$

It may be helpful for the reader to understand the structure and function of the Portland police chief position. Moose was presenting his report at the behest of the City

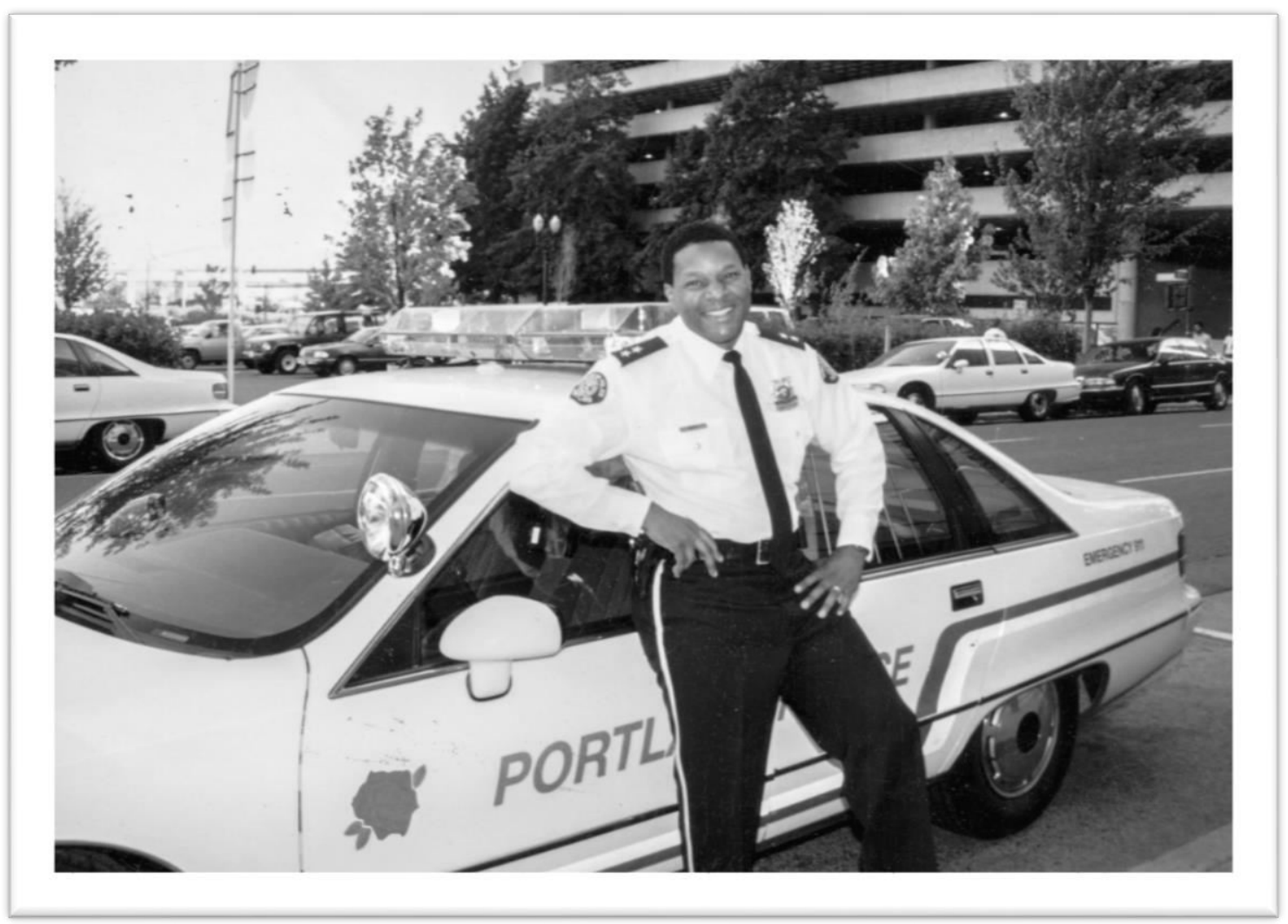

Figure 16 Chief Charles Moose. Courtesy of Oregon Historical Society, Image bb013832

Council. He was appointed by the mayor and required to do what the council instructed him to do. His was a political position. Moose discussed this structure in his PhD thesis when he reviewed Chief Richard Walker's tenure under Mayor Bud Clark. Moose wrote,

${ }^{676}$ Bernstein, “Moose Lashes Out,” A 01. 
"Walker seemed to understand that as the Chief of Police he was expected to use his knowledge of the bureau and his law enforcement experience to implement the will of the Mayor."677 Moose added that as Clark had campaigned as "an outsider determined to open City Hall and other bureaucracies (including the police) to the regular citizens of Portland, it was only a matter of time before he would find a chief who would understand and pursue his goal." 678 Moose was playing with political fire, and pushing the accepted and established boundaries of the chief of police position. And he knew it, too.

Moose was angry that he had been asked to prepare an extensive report on the incident to the council. He was defiant to the council. "It's absolutely insulting to spend the amount of energy we've spent on whether or not we can have an illegal birthday party. It is very, very insulting the energy that has been going into this," Moose told the city council. ${ }^{679}$ Moose described the numerous issues affecting the community - drug dealing, an abundance of adult clubs and escort services, and a very serious shooting at a Delta Park Shari's restaurant that resulted in the death of a black man. "I have no phone calls in my office about the death of that young man, and I'm still getting calls about the beach party. It's very, very insulting about the energy that has gone into this whole matter."680

\footnotetext{
677 Charles Moose, "The Theory and Practice of Community Policing: An Evaluation of the Iris Court Demonstration Project" (PhD diss., Portland State University, 1993) 69.

678 Moose, "The Theory and Practice of Community Policing," 69.

679 Bernstein, "Moose Lashes Out," A 01.

680 Tonya Y. Parker, “Moose Lashes Out at Critics," The Portland Skanner, 11/18/1998, 19.
} 
Moose laid some of the issue right at the feet of the council. He warned that Northeast Portland residents say that white people have "The Bite," and that when these same residents ask why they are not allowed to have similar events in their community, "this indicates there are larger issues to deal with than just questioning the Police Bureau." ${ }^{681}$ Moose declared that the council "should look a little deeper at the root causes, underlying conflicts and the lack of equal treatment that is occurring in Northeast Portland." 682 The chief stated that unlike the council, the police bureau was already doing this. He said that when the police examined the problem, they see "abandonment, poverty and unequal treatment... and try hard to make a difference." 683 Moose was bringing his gritty, street level view of community policing, right into the hallowed halls of the city council itself.

Moose then described his personal feelings: "Why should I work on trying to improve my neighborhood, improve job opportunities, improve schools, when the people of Northeast Portland only want to assure that Mr. Binns is allowed to have his birthday party? All I'm trying to express is my personal frustration. We've spent a disproportionate amount of energy and time on whether or not we can have a party. And if we would spend this amount of time and energy on our schools, on jobs, on economics, on education, then I guess I would feel better that we have a chance." 684

\footnotetext{
${ }^{681}$ City of Portland Archives, Official Minutes, 11/18/1998, 9.

682 City of Portland Archives, Official Minutes, 11/18/1998, 9.

${ }^{683}$ City of Portland Archives, Official Minutes, 11/18/1998, 9.

${ }^{684}$ Steve Duin, "Reaction to Moose Generally Favorable," The Oregonian, 11/22/1998, C 01.
} 
Moose explained to the council what he was feeling as the protest surrounded his home. "I felt captured, and I felt unable to defend my home or my house. We felt extremely threatened by what was going on there." ${ }^{685}$ He stated that the "clear decision" that moving to the neighborhood was a mistake was reinforced by "the public display that had been given to Mr. Binns, and the endorsement of the protest at my house." ${ }^{686} \mathrm{He}$ also said he had received threats and hate mail since the protest. Moose seemed to be calling out his neighbors specifically.

Then he dropped a bombshell: "The decision by Sandy and myself to live in the neighborhood is a joke and a major mistake... Yes, we will stay in our house, but the commitment to the community has been taken away." 687 This was heady, viscous stuff. Here was the leader of the success story that was community policing in Portland abandoning his program. Moose was respected for this move by the national press and by the U.S. Attorney General. He had taken his own initiative to move into the King neighborhood, without political pressure from above and with no incentive of lower house payments from the system. It had been classic Charles Moose - he just did it. And now he was declaring that it was a major mistake to the political body that had appointed him to his position.

\footnotetext{
${ }^{685}$ Bernstein, "Moose Lashes Out," A 01.

${ }^{686}$ Bernstein, "Moose Lashes Out," A 01.

${ }^{687}$ Bernstein, "Moose Lashes Out," A 01.
} 
The Binns protest had struck to this man's core; this was something that he not only believed - but LIVED. He was devoted to his community. It's who he was. Conversing with the children, helping get bikes to kids that had lost them, assisting the postal worker whose pants were a little raggedy, being an active member of this community, was part of his identity. Being a role model was part of his very persona. It's exceptionally hard to imagine Charles Moose not involved in that community, and regretting his commitment to the King Neighborhood. His wife, Sandy, had even been invested enough to build a large addition to the home for her law office. The Mooses were financially tied to the neighborhood.

Moose did offer the slightest conciliatory branch at the council meeting, however. He said that if he had "misjudged the community's priorities" then he welcomed feedback, but he admitted that he was "very confused about them at this point."688

Commissioner Hales seemed to come to the chief's defense. He said he did not think that the chief's priorities were wrong, and he hoped that Moose would stay committed to them. He felt that a lot of "good work" was being done for the community in Northeast Portland, by the police as well as others. Hales agreed with Moose that "people sometimes focus on the wrong things." 691 He also asserted that, "No one should operate on the mistaken belief that the chief's house is City Hall and the place to go

688 City of Portland Archives, Official Minutes, 11/18/1998, 11.

${ }^{691}$ City of Portland Archives, Official Minutes, 11/18/1998, 11. 
protest. People should remember that he has a right to have peace and safety in his own home." 692

Commissioner Jim Francesconi seemed to try to push back a bit on Moose's casting of blame. The commissioner said that if the police did not "continue to advocate for such things as after school programs, the City will not get beyond race and poverty factors." ${ }^{\prime 693}$ Commissioner Erik Sten was also a tad more accusatory. He told Moose that he had heard concerns "about how the police and community relate on things like parties." Sten pointed out "the long-time belief that the police lean harder on gatherings in Northeast than other parts of town. It is a fact that there is a higher police presence around MLK (Martin King Luther Jr. Blvd) than other busy streets." ${ }^{994}$ But Sten did agree that it was a mistake for "the community" to have marched on Chief Moose's house, that he believed that "great progress has been made by the Police Bureau on some of the underlying issues," and that he hoped that that progress would continue. ${ }^{695}$

Moose attempted to clarify his statements somewhat after his emotional eruption to the Council, but his remarks really did nothing to improve the situation. He said that his commitment to the bureau remained, but he wondered whether it was "worth his time

\footnotetext{
692 City of Portland Archives, Official Minutes, 11/18/1998, 11.

${ }^{693}$ City of Portland Archives, Official Minutes, 11/18/1998, 10.

${ }^{694}$ City of Portland Archives, Official Minutes, 11/18/1998, 11.

${ }^{695}$ City of Portland Archives, Official Minutes, 11/18/1998, 11.
} 
and effort" after the protest to help the community on other issues as he had in the past. ${ }^{696}$

Needless to say, Moose's public outburst was all the talk in the city of Portland. After news of the comments splashed across the papers, radio, and television news programs, the Mayor's Office received forty five calls demanding Moose's resignation. ${ }^{697}$ Moose was still defiant the next day. His comments did seem to be pointed at the African American community of Northeast Portland. ${ }^{698}$ Moose was questioning all of the dedication he had thrust into the community and in being a contributor as well as a role model. "The 'thank you' is that they come and march on my house. So maybe I should just do the minimum. I'll do my job at the Police Bureau, but whether I should go to some school and be reading or working with kids... if I'm the only person, and it's not a priority for the people of Northeast Portland, all I'm saying is thank you for that message."699

Moose addressed the African American community directly and said that they needed to focus their energy on other, more looming problems than an illegal August birthday party. He gave what he considered a "wake up call." "I want the people in the community I live in to get involved in real issues and to be more concerned about things that are impacting their livability," he said, "I've been doing my job, and I'm going to

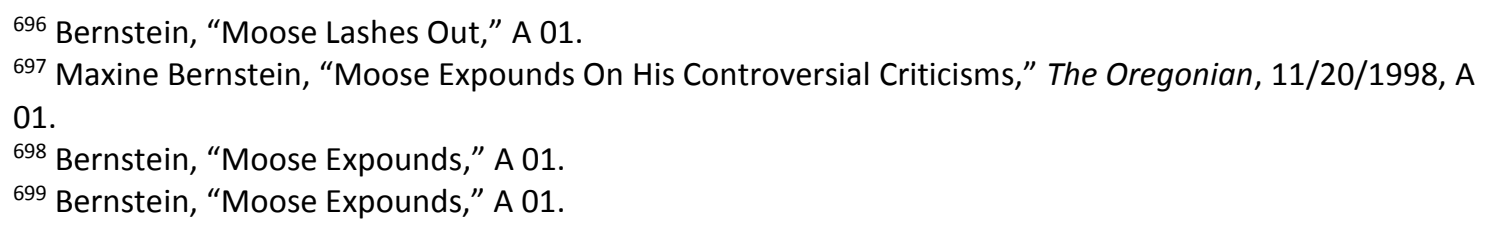


always do my job. I'm committed to staying here in Portland, but I guess the question is, 'Who else is willing to work on issues in Northeast Portland?'" 700 Seven months later, Moose resigned and accepted another position across the country.

He also called the council to the carpet, referring to the previous day's report as "a big show." Moose explained that he had been the police chief for five years and had never previously been asked to review anything before the council. Preceding shootings and serious issues in police behavior that resulted in deaths had never before drawn the council's attention. "I didn't need to go in front of the City Council and do all of that," he said. ${ }^{701}$ Moose added that, "I guess it's unfortunate that there wasn't any other chance for me to talk to the City Council until yesterday. So I guess it's just taken between August and now for me to say what I've felt. I have to say and do what I think is right. If it results in my getting fired, so be it. I don't get to be police chief forever. Nobody does. I'm very fortunate to have this job. I'm very blessed." ${ }^{\prime 702}$

But Moose was not finished. He also had thoughts on the diversity of the City Council: "A city this size, with the problems we have in the African American community. Look at our leadership." ${ }^{703}$ He went on: "I went to live in the African American community. You have to go where the problems are, where the people have felt left out. Where there's greater poverty. Where people feel disenfranchised. Where the job opportunities are

\footnotetext{
700 Bernstein, "Moose Expounds," A 01.

701 Bernstein, "Moose Expounds," A 01.

702 Bernstein, "Moose Expounds," A 01.

703 Bernstein, "Moose Expounds," A 01.
} 
the worst. Where the crack houses are. That's where we need to try to make the difference." But, he added "I'm not committed to trying to do it alone."704

Moose next took apart his incentive system, the Police At Home program, a corner stone of his community policing policy. "I used to give [my police officers] a speech about living in Portland, but I won't do that because I can't honestly tell anybody that they should put themselves or their family through what I went through."705 This was a sacred cow of Moose's community policing plan - getting the officers of Portland into the neighborhoods they policed and entrenching them into these troubled streets- not only as police officers, but as neighbors that were active in their community and role models for the children to look up to. Moose was now convinced that this strategy was not worth the effort.

The commissioners were straightforward with the press about Mooses's statements. They knew the anger within the community that his comments had caused. Commissioner Charlie Hales wondered if maybe Moose had just been having a "bad day," and that, "I think it was unfortunate that the chief felt he had to make those comments before the council." Hales added, however, that "I think he's a good chief and should stay." ${ }^{\prime 706}$ Commissioner Erik Sten correctly observed, and possibly diplomatically stated, that "The chief's always been very outspoken. So whether or not

\footnotetext{
704 Bernstein, "Moose Expounds," A 01.

705 Bernstein, "Moose Expounds," A 01.

706 Bernstein, "Moose Expounds," A 01.
} 
it hurt his ability to serve as chief depends on what happens next." ${ }^{707}$ But Sten did agree "wholeheartedly that the protest was a symbol of something more than the police response in this one case." ${ }^{\prime 08}$ Later, Sten would say that "There were times he drove me nuts. We're trying to ask him questions about a serious incident, and he gets really mad at us. He has a temper, and we all saw it." ${ }^{109}$ City Commissioner Jim Francesconi felt that "as far as the Northeast community, he painted it with too broad of a brush." ${ }^{710}$ But Francesconi did feel that the chief's "outburst" was a major setback for community policing. ${ }^{711}$ Moose's anger again got the best of him.

Responses from the black community in the aftermath of Moose's tirade were well represented. In her article on the outburst, Tonya Parker of The Portland Skanner wrote that "it took only a few words to incite feelings of anger, confusion, disappointment and hurt in many Northeast Portland residents." ${ }^{172}$ Lolenzo Poe, chairman of the Coalition of Black Men, observed that 'from the calls I've been getting, there's a real level of shock, disappointment and outrage. The chief owes the Northeast Portland community, and, in particular, the African American community, an apology." ${ }^{713}$

\footnotetext{
${ }^{707}$ Bernstein, "Moose Expounds," A 01.

${ }^{708}$ City of Portland Archives, Official Minutes, 11/18/1998, 9.

709 Maxine Bernstein "Moose Closes Out 6-Year Tenure of Achievement, Pitfalls as Chief," The Oregonian, 7/28/1999, A 01.

${ }^{710}$ Wade Nkrumah \& Gwenda Richards Oshiro, "Reaction to Moose Generally Favorable," The Oregonian, 11/21/1998, B 01.

${ }^{711}$ Nkrumah and Oshiro, "Reaction to Moose Generally Favorable," B 01.

712 Parker, "Moose Lashes Out at Critics," 1.

${ }^{713}$ Nkrumah and Oshiro, "Reaction to Moose Generally Favorable," B 01.
} 
Poe also shared concerns about what the advice the chief was dispensing would mean to Portland police officers. Poe declared that message as "scary." He said, "If the chief is saying, 'I give up, there's nothing I can do for them,' that almost gives them license to deal with the community in any way they see fit. I don't think he would say it, nor would it have been tolerated, if it had been said about Southwest Portland." ${ }^{14}$

A few days later, after the dust had settled a bit, letters began trickling into the mayor's office. These documents provide a real snapshot of the tension of the community, and a social history of the thoughts and feelings of Portlanders on important topics like race and policing. Thomas Kearns wrote, "the recent declaration by Moose that he can no longer support the community (whether his home neighborhood or the city at large was not made clear), seems to me to be an opportune time for you to fire him outright. If he feels bold enough to make this public declaration, then it is time for him to go, and to go immediately! FIRE HIM!"718

Most of the letters to the mayor have a positive take on Moose's comments. Sandra Golden wrote that she supported the chief and that, "He said out loud what a lot of people think. He has worked hard to make a difference! I'm tired of hearing people complain, especially when they do not take an active role in making things better. I hope

\footnotetext{
714 Nkrumah and Oshiro, "Reaction to Moose Generally Favorable," B 01.

718 City of Portland Archives, A2005-004, 0252-01, Mayor Vera Katz Subject Files, Internal Staff Files: Chuck Bolger, 1998-1999, Box 2, file “Constituent letters to Chief of Police Charles Moose," letter from Thomas E Kearns, 11/20/1998.
} 
Chief Moose doesn't give up!"719 Walter Morris stated that he had "seen the efforts

Chief Moose has applied to make positive changes to improve the lives of our youth and community only to be rebuffed by many who traditionally will be historically adjutators [sic] and blame others for their failures." ${ }^{20}$ Gordon Bussey asked the mayor to "please tell Chief Moose not to sweat this one. Those of us who value law know we're damn lucky he's in Portland, rather than D.C. or points east."721

Melvin Cearley of Woodland, Washington, wrote Chief Moose a letter of support and sent a copy to Mayor Katz. Cearley, a self-proclaimed "old Texas red-neck," wrote, "the fact that you dare be "politically incorrect" and call a spade a spade is too much for a bunch of spoiled, soft headed brats to handle. The community should picket your house, but in honor and support! You are the best thing to happen to the Portland police department since I have lived in this area (20 years)." 722

Carol Heacock of Northeast Portland said that she and her husband were "so thankful that you and your wife have chosen to make your home in our neighborhood!" The Heacocks had been at Sellwood Park on the day of the Binns party, attending a picnic of

\footnotetext{
719 City of Portland Archives, A2005-004, 0252-01, Mayor Vera Katz Subject Files, Internal Staff Files: Chuck Bolger, 1998-1999, Box 2, file "Constituent letters to Chief of Police Charles Moose," letter from Sandra Golden, 11/20/1998.

720 City of Portland Archives, A2005-004, 0252-01, Mayor Vera Katz Subject Files, Internal Staff Files: Chuck Bolger, 1998-1999, Box 2, file "Constituent letters to Chief of Police Charles Moose," letter from Walter Morris Jr., 11/19/1998.

721 City of Portland Archives, A2005-004, 0252-01, Mayor Vera Katz Subject Files, Internal Staff Files: Chuck Bolger, 1998-1999, Box 2, file "Constituent letters to Chief of Police Charles Moose," letter from Gordon Bussey, 11/30/1998.

722 City of Portland Archives, A2005-004, 0252-01, Mayor Vera Katz Subject Files, Internal Staff Files: Chuck Bolger, 1998-1999, Box 2, file "Constituent letters to Chief of Police Charles Moose," letter from Melvin Cearley, 11/23/1998.
} 
the Northwest Adoptive Families Association. ${ }^{723}$ Describing it as "that awful day," Ms. Heacock said that they "saw the police in action first-hand. We were grateful for their protection, not knowing that they would soon essentially be following us home, and continuing to protect us not too far from our own neighborhood. Again we thank you and your officers." 724 She concluded the letter by thanking Chief Moose for being such a good role model "for our daughter, and for all children, especially for our children of color."

What had precipitated Moose's outburst? His response was quite a departure from his comments to the City Club of Portland five years earlier when he explained the Bureau's role in his "No Duty To Retreat" speech. Moose explained at that time that the role of the police in that context was "that we have to continue to be an open organization, to allow people to participate in our policies and our procedures. To participate in giving us direction and telling us what they would like to see police officers do, how they want police officers and police work performed in their city... It means that when you as a group bring forth some of those very tough questions about police policy, and you want to know why it is that we're doing things a certain way, then we have to be an open enough organization to allow you access to everything that we're doing, so

\footnotetext{
${ }^{723}$ City of Portland Archives, A2005-004, 0252-01, Mayor Vera Katz Subject Files, Internal Staff Files: Chuck Bolger, 1998-1999, Box 2, file “Constituent letters to Chief of Police Charles Moose," letter from Carol Heacock, 11/19/1998.

724 City of Portland Archives, letter from Carol Heacock, 11/19/1998.
} 
that somehow you can make a better decision on whether or not we're doing that correctly." 725

As much as he may have disagreed, the Binns party protest did just that. The marchers were outside his home, the place he had chosen to practice community policing, and they were attempting to "participate in our policies and procedures." Those protestors were quite clearly participating in giving the police direction "and telling us what they would like to see police officers do." The protestors were indeed doing this as a group, bringing forward "very tough questions about police policy." Was Moose only seeking the input of the largely white, educated members of the Portland City Club? The City Council had asked for "access to everything," and yet Moose called the exhaustively detailed Binns Beach Party report "absolutely insulting."

Moose later stepped back from his City Council statements. He said, “I didn’t do an adequate job of articulating my feelings at the council. Those were ill-prepared comments." ${ }^{726}$ But it was too little, too late. The damage had been done. As Lilian Sevier Adams, a King neighborhood resident, said, “I heard he didn't like the neighborhood. He apologized after he said it, but the truth was already out." ${ }^{127}$

In March 1999, a Multnomah County judge found Daniel Binns guilty of one count of disorderly conduct for his involvement in his illegal birthday party. Binns was sentenced

725 City Club of Portland, "New Directions For Portland's Police Department." 8/6/1993. https://www.youtube.com/watch?v=eP1UXxiVBqo\&feature=youtu.be

${ }^{726}$ Bernstein "Moose Closes Out 6-Year Tenure," A 01.

${ }^{727}$ Wade Nkrumah, "Neighbors Show Range Of Opinion On Moose," The Oregonian, 5/28/1999, D 02. 
to 240 hours of community service, and the judge ordered that all future parties were to include a safety plan developed in concert with the bureau. ${ }^{731}$ In addition, Binns received a "courtroom lecture" from Commander Derrick Foxworth. The Oregonian relayed that "Foxworth told Binns he should spend his time tutoring students instead of throwing parties featuring scantily clad women."732

Was Moose too rash in his reaction? Had his anger taken over, and had he lost control once again?

In July 1999, just a few days before he left Portland, Moose admitted that at times he was too rash. "If you take action, you can't take it back. I think I've got to work on slowing down the processes. ${ }^{733}$

By the time Moose was getting ready to leave Portland for the Washington D.C. area, it seemed that his legacy had been established. King Neighborhood residents had several responses regarding his departure. As active as Moose was in the community, Portland's "most visible police chief" just was not transparent enough to the residents in the actual confines of the neighborhood. Joseph Fuller said, "He didn't live up to that expectation as far as getting to know his neighbors. When they talk about neighborhood

\footnotetext{
731 David Austin, “Man Who Led Protest In 1998 Is Found Shot,” The Oregonian, 12/15/2003, B 07.

732 Austin, "Man Who Led Protest In 1998," B 07. Unfortunately, the story of Daniel Binns took a very sad turn. On December 14, 2003, Binns was found at about 1 in the morning on the ground in a vacant office building at the 3500 block of NE Martin Luther King Jr. Blvd. He was bleeding from a gunshot wound to the head. Witnesses to the shooting, which some say took place at an after-hours illegal bar, were reportedly too afraid to identify Binns's shooter. See also Angela Valdez, "After Hours; Inside Portland's Illegal Club Scene," Willamette Week, 4/19/2005. Accessed online, 5/31/2016.

http://www.wweek.com/portland/article-4319-after-hours.html

733 Bernstein, “Moose Closes Out 6-Year Tenure," A 01.
} 
policing, that means walking the beat."734 Lilian Sevier Adams said, "We knew he lived over here somewhere," but felt that Moose just left his home to go to work. The apathy was obvious. Adams recalled that she recognized Moose only by seeing him in the paper and on television, noting that she had never seen his face in the neighborhood. Linda Sevier Sherman (Lillian's sister) agreed when she simply stated “He has not been visible."735

One reporter, Wade Nkrumah, wrote that "Moose's visibility never seemed to catch up with the profile of his house." 736 King resident Eric Turner agreed that Moose was not visible in the neighborhood. "That didn't happen," Turner said. "We didn't see him, hear from him or talk to him. He had the upper hand simply by moving into the neighborhood."737 However, Turner did concede that Moose's move into the King neighborhood was a significant step in the development of the community. "That was big for minorities," he said, "I know when I ride by his house, I always take a second look."738

Roughly six months after his emotional statements to the City Council, Charles Moose would be leaving Portland for good. But Moose had one more high profile, national stage spectacle to execute before he left his city.

\footnotetext{
734 Nkrumah, “Neighbors Show Range," D 02.

735 Nkrumah, "Neighbors Show Range," D 02.

736 Nkrumah, "Neighbors Show Range," D 02.

737 Nkrumah, "Neighbors Show Range," D 02.

738 Nkrumah, “Neighbors Show Range," D 02.
} 
NOBLE is the acronym for National Organization of Black Law Enforcement Executives.

The mission of the organization is to "work with the community to achieve greater involvement and cooperation with criminal justice agencies, to have a positive impact on urban crime and violence, and to provide a platform from which the concerns and opinions of minority law enforcement executives and members can be expressed on the major problems of crime and delinquency in metropolitan areas." ${ }^{739}$ NOBLE is to this day a very active professional organization.

The founding of NOBLE occurred in 1976 during a three day symposium in which sixty black law enforcement executives gathered in Washington D.C. to discuss issues facing the black community. One of the items discussed was "the unique problems of the black police executive." 740

An interesting anecdote suggests why a black police officer's organization was necessary. Sergeant Thomas Hall, a Virginia state trooper, explained: "In America, we need independent black institutions... to foster cultural pride, and have a place where we can go and feel comfortable. We cannot express ourselves in society. We cannot assimilate in society. We cannot even assimilate like some Hispanic groups can because of their complexions. I can't assimilate on a bus. As soon as I step on a bus, you are

\footnotetext{
${ }^{739}$ City of Portland Archives, B/030226, 24-02-15, Subject Files, Police: Mayor's Office, 1993-1996, Police Related Press Releases/Video Tapes, file "April - Aug 1996," "Portland Police Chief Charles Moose To Host National Organization Of Black Law Enforcement Executives (NOBLE), Northwest Chapter Officers Installation Dinner," 5/24/1996.

740 National Organization of Black Law Enforcement Executives webpage, History of Noble. Last accessed, 4/15/2016. http://www.noblenational.org/history.aspx
} 
going to realize there is a black guy on the bus. I can't assimilate in a police organization... so without these black institutions, I cannot survive. We all have survival mechanisms. I have cultural needs and I have to be around people that share my needs and frustrations. I cannot do that in organizations that are predominately white. The whites don't suffer from the racial pressures and tensions that I suffer from. So how can they [mostly white organizations] meet my interests and needs? It is impossible." ${ }^{741}$

The twenty-third annual NOBLE conference was held in Portland at the Jantzen Beach Double Tree Hotel. The five-day event ran from Friday, July 23 to Monday, July 26, 1999. ${ }^{72}$ The theme of the conference was "NOBLE the Tradition: Now the Necessity for the $21^{\text {st }}$ Century." 743

Moose was instrumental in bringing the NOBLE conference to Portland, and Moose was listed as the Conference Co-Host Chief. ${ }^{745}$ Moose had been involved with the organization for some time. In June of 1996, he hosted a Northwest Chapter Officers Installation Dinner at Atwater's restaurant, on the thirtieth floor of the U.S. Bank

\footnotetext{
${ }^{741}$ R M Shusta ; D R Levine ; P R Harris ; H Z Wong, Multicultural Law Enforcement: Strategies for Peacekeeping in a Diverse Society, (Upper Saddle River, NJ: Prentice-Hall, Inc, 1995) Accessed online, 4/145/2016. http://wps.pearsoncustom.com/wps/media/objects/10774/11033223/CJ310_Ch02.pdf 742 Maxine Bernstein, "Police Officers March For A Noble Cause," The Oregonian, 7/29/1999, C 01, and "NOBLE $23^{\text {rd }}$ Annual Training Conference and Exhibition Preliminary Schedule," obtained from Valerie Shufford, Director of Conferences, NOBLE Natl Office, Alexandria, VA, 4/14/2015.

743 “NOBLE $23^{\text {rd }}$ Annual Training Conference and Exhibition Preliminary Schedule," obtained from Valerie Shufford, Director of Conferences, NOBLE Natl Office, Alexandria, VA, 4/14/2015.

745 Bernstein, "Moose Closes Out 6-Year Tenure," A 01, and "NOBLE $23^{\text {rd }}$ Annual Training Conference and Exhibition Preliminary Schedule."
} 
Tower. ${ }^{746}$ In June of 1998, he attempted to have Director of the Federal Bureau of Investigation, Louis J. Freeh, deliver the keynote address to the attendees. ${ }^{747}$

Robert L. Stewart, executive director of the conference said, "We aren't well known in the Pacific Northwest." Part of the stated reason for hosting the conference in Portland was that the organizers "thought this would enhance our image and our role" in the region. ${ }^{748}$ And the Pacific Northwest may not have been known to many of the NOBLE attendees either. In a full page advertisement for the conference in NOBLE's Noble Actions newsletter, a glossy ad with a bright red rose proclaimed "this conference promises to be an exciting time for all," and that "we are expecting a truly rewarding experience in Portland." ${ }^{\prime 49}$ The conference drew over 1,800 attendees. ${ }^{750}$

The conference was held on the last week of Moose's tenure as chief of police. Robert L. Stewart, executive director of the NOBLE conference said "it gives us a unique opportunity to celebrate Moose's tenure."751 Moose, and his successes with and contribution to policing in Portland, was absolutely honored with this conference; in

\footnotetext{
${ }^{746}$ City of Portland Archives, B/030226, 24-02-15, Subject Files, Police: Mayor's Office, 1993-1996, Police Related Press Releases/Video Tapes, file "April - Aug 1996," "Portland Police Chief Charles Moose To Host National Organization Of Black Law Enforcement Executives (NOBLE), Northwest Chapter Officers Installation Dinner," 5/24/1996.

747 Portland Police Bureau Record Request, June $5^{\text {th }} 1998$ letter from Charles Moose to Kathleen L. McChesney, Special Agent In Charge, FBI, Portland.

748 Maxine Bernstein, "Black Police Conference Starts Today," The Oregonian, 7/24/1999, D 06.

${ }^{749}$ Noble Actions, Volume 98, Number 3, Fall 1998, 10.

750 "Community Policing: Ten Years of Partnerships," Portland Police Bureau 1999 Statistical Report. Accessed online 4/15/2016. https://www.portlandoregon.gov/police/article/29800

${ }^{751}$ Bernstein, "Black Police Conference Starts Today," D 06.
} 
fact, it seems to have been a second, thinly veiled theme of the conference. On July 23 , NOBLE hosted a "special reception" for Moose. ${ }^{752}$

But conferences are not just thrown together - a huge amount of labor had to be conducted to get the conference going. Finances, of course, needed to be considered. In the committee timelines, raising $\$ 150,000$ in cash or in-kind donations became the task of the fundraising committee. ${ }^{760}$ It appears that the local committee may have fallen short of that goal. An internal memo on "local" sponsors listed $\$ 51,500$ in cash donations promised, with another $\$ 5,550$ in-kind donations promised. ${ }^{761}$

Aggressive solicitation of donations occurred. At a February fundraising lunch at the Portland Embassy Suites Hotel, Chief Moose told the gathered business leaders that the NOBLE Conference was a chance for them "to meet African-American law enforcement executives who were also leaders in their communities." ${ }^{\prime 764}$ Mayor Katz also addressed the group, noting that this was a chance for these businesses to gain national exposure and an opportunity for the City to embrace diversity. She added that it was "a community opportunity to work with local African-American leaders on the Host City

\footnotetext{
752 “NOBLE Meets, Honors Moose,” The Portland Skanner, 07/28/1999, 8.

760 City of Portland Archives, NOBLE Collection, File: 1999 NOBLE Conference, Committee Timelines, "Fundraising."

${ }^{761}$ City of Portland Archives, NOBLE Collection, File: 1999 NOBLE Conference, Committee Timelines, "List Of Local Noble Sponsors." There seems to have been some cash flow issues with the Northwest NOBLE Conference. In the summaries of the March 12, 1999 Mayor-Chief meeting, a note says "NOBLE conference. The mayor agreed to contact Pat LaCrosse at OMSI to see if the rates at the facility can be reduced for this conference." See City of Portland Archives, Box 26-04-17, "Office of Mayor Vera Katz, Policy \& Historical Records, General Files - Police," “Mayor-Chief Meeting Summaries, March 12, 16 and 23, 1999."

764 City of Portland Archives, NOBLE Collection, File: 1999 NOBLE Conference, Committee Timelines, "Northwest Noble Conference Fundraiser Lunch, 2/26/1999."
} 
committee." 765 Race was a marketable aspect of the conference, and it was leveraged to the white Portland business community.

Moose seemed proud of the conference when he described it to the City Club of Portland attendees in July of 1999. "We have over 2,000 African American chiefs, leaders in the law enforcement professions, visiting the city of Portland, to talk about their business, to talk about how NOBLE plays a key role in moving policing into the $21^{\text {st }}$ century, not just in Portland, but nationwide." ${ }^{767}$ This was a unique opportunity for Moose, as he was exiting the job, to tell the social elite of Portland how black officers, like himself, were instrumental in creating and promoting revolutionary law enforcement initiatives in the national context. But it was also an opportunity for Moose to promote Portland, a harbinger of community policing, to the national stage and to bring the municipality to the forefront of law enforcement leaders. Portland was a place where new ideas were tested and successfully implemented. Portland was where esoteric strategy and theory were played out on the real live pavement of North and Northeast Portland.

Topics discussed in the conference's workshop series included some predictable subjects for a law enforcement meeting: Investigative Trends in Drug Enforcement, Family and Domestic Violence, and Managing Rural and Small Town Police Departments.

\footnotetext{
765 City of Portland Archives, "Northwest Noble Conference Fundraiser Lunch, 2/26/1999."

767 City Club of Portland, "The State of Portland Police." 7/23/1999.

https://www.youtube.com/watch?v=SXLLTs81WPE\&feature=youtu.be
} 
True to the focus of the organization's mission, there were also topics that appealed to NOBLE's Black constituents: The Glass Ceiling: What is the Impact on Black Women, in addition to Discrimination Issues (this one featuring Penny Harrington, former Portland police chief and the nation's first female police chief, as a panelist). ${ }^{768}$

As one might expect, some of the workshops extracted the theme from the conference into their topic. "Gangs: Approaches for the $21^{\text {st }}$ Century" was offered by the "Slick Boys" of the Chicago Police Department and Ron Carter of the Bureau of Alcohol, Tobacco and Firearms. ${ }^{769}$ "Hate Crimes at Abortion Clinics, Churches and by Right-Wing Extremists" examined these "national tragedies" at a time when skinhead and militia activity was at a high point in the Pacific Northwest. ${ }^{770}$ Representatives of the U.S. Postal Inspection Service and the FBI presented a session on "Cyber Crimes," an examination of fighting capers that were "relating to illegal activities conducted through the use of computers and related information systems." 771

For the student of Charles Moose's career, one cannot help but find a few ironic sessions distributed throughout the conference's schedule. The description of "Law Enforcement: Operating in a Politically Sensitive Environment" observed that "law enforcement executives in order to survive and prosper, must develop expertise on how

\footnotetext{
768 “NOBLE $23^{\text {rd }}$ Annual Training Conference and Exhibition Preliminary Schedule."

769 The Slick Boys were a rap group composed of three Chicago Housing Authority youth officers. Jeff Lyon, "Good Cop, Bad Cop," The Chicago Tribune, 3/9/1997. Accessed online on 5/31/2016, http://articles.chicagotribune.com/1997-03-09/features/9703090137 1 chicago-cops-slick-boys-bad-cop 770 “NOBLE $23^{\text {rd }}$ Annual Training Conference and Exhibition Preliminary Schedule."

771 “NOBLE $23^{\text {rd }}$ Annual Training Conference and Exhibition Preliminary Schedule."
} 
the political process functions, as it affects selection, promotion and continued opportunities." The program promised the attendee "a practical guide to assessing the political environment and recognizing the opportunities and pitfalls it presents." 772 "The Officer Next Door Program (OND)" was offered by the U.S. Department of Housing and Urban Development. The OND was described as "a key element of the Clinton-Gore Administration's commitment to strengthening America's communities. The presentation detailed the program, which offered "HUD-owned, single family homes to law enforcement officers at a 50 percent discount in selected revitalization areas. It helps to prevent crime and promotes neighborhood safety and security by encouraging law enforcement officers to become homeowners in economically distressed communities." 773 Thankfully for the presenters, Chief Moose was not a panelist for the discussion.

In addition to officiating at the Welcoming Address, Chief Moose did present on a panel. It was certainly a wonderful match, providing him an opportunity to share from his depth of knowledge on the topic, on a national scale. The description of the session on "Community Policing: What Works and What Doesn't" promised that the panel would "look at the controversial issue of law enforcement partnering with communities through Community Policing Philosophy. It concentrates on a cooperative framework for relationships between people and police." ${ }^{174}$ It is important that we take a step back

772 "NOBLE $23^{\text {rd }}$ Annual Training Conference and Exhibition Preliminary Schedule." 773 "NOBLE $23^{\text {rd }}$ Annual Training Conference and Exhibition Preliminary Schedule." 774 "NOBLE $23^{\text {rd }}$ Annual Training Conference and Exhibition Preliminary Schedule." 
and examine that statement. "Community policing" was not a known "philosophy" in the rest of the nation. The organizers of a national law enforcement conference felt it was actually necessary to explain the topic. And even to those familiar with the terminology, community policing was still "controversial." This is just another indication of how revolutionary of a leader Charles Moose was, and how forward thinking the 1990s Portland Police Bureau had been in community policing.

NOBLE also offered a symposium for law enforcement CEOs. The thirty-sixth annual conference's symposium was a forum between the law enforcement officers and various community leaders discussing racial profiling and excessive use of force. ${ }^{775}$ The Portland Skanner noted that "the panel heard the views of law enforcement executives, legislators, legal experts, federal officials, community leaders and civil rights activists." The writer noted the attendance of panelists lawyer Johnny Cochran (often remembered for his role In the O.J. Simpson trial, but also known as an advocate for the black community and for battling police brutality) and the U.S. Department of Justice, Civil Rights Division Chief, Steve Rosenbaum.

A tradition of the annual NOBLE Conference is the Memorial March. The march is held every year to remember fallen NOBLE officers who died the year before. But this march was also a stirring display for the black community in Northeast Portland - the same

775 “NOBLE Meets, Honors Moose,” 8. 
community that Moose had tried to connect to, the community he had insulted, and one that in a few days, he would be leaving.

Regarding the Wednesday march, Portland Sgt. Dorothy Elmore said, "This will also give Portland a chance to be aware that there are these many high-ranking African American officers and leaders in this country." 776 Surely there was no coincidence that the Memorial March was to begin at King School Park on Northeast Going Street, right by the Mooses' home. If the routing of the march WAS just coincidence, it was pregnant with irony. According to the timeline established by the national NOBLE organization, the Memorial March's location and basic route was to be laid out by October $30^{\text {th }}, 1998$ - just as Moose was compiling all the records and reports requested by the City Council for the findings on the Binn's march. ${ }^{777}$

Seventy-one year old Lawrence Wells, a Northeast Portland resident, saw the import of the display, even if he was unaware of Moose's role in placing it in his neighborhood. Wells said "I got up for this. We didn't have many African Americans in law enforcement when I was a boy. It's great to see this." ${ }^{\prime 78}$ Paul Knauls, who owned Geneva's Shear Perfection Barber \& Beauty Salon, said, "It's very important that we are represented."779

\footnotetext{
776 Bernstein, “Black Police Conference Starts Today," D 06.

777 City of Portland Archives, NOBLE Collection, File: 1999 NOBLE Conference, Committee Timelines, "Memorial March Organizational Timeline."

778 Bernstein, "Police Officers March," C 01.

779 Bernstein, "Police Officers March," C 01.
} 
One of the conversation threads at the conference was racial profiling. James Golden, organization president and chief of the police department in Saginaw, Michigan, said that racial profiling was "immoral. This is unethical. There ought to be policies and procedures to prohibit such conduct. This practice must stop." 780 Reporter Maxine Bernstein noted that racial profiling resulted in "the perception among minorities that police target them disproportionately when making traffic stops." ${ }^{781}$ It was indeed a hot topic at the conference.

And, yet again, Moose was regarded by the conference organizers as a stalwart in developing steps to oppose racial profiling. In April 1999, Moose signed a resolution, one that he had drafted, along with representatives of twenty-three other Oregon police agencies. ${ }^{782}$ The signers agreed that they would "not tolerate police actions based on a person's race." ${ }^{783}$ This measure was groundbreaking on a national scale. Robert Lamb, regional director of the U.S. Department of Justice's Community Relations Service, was quoted at the time as having said "to my knowledge, this is the first time that police executives and union officials together have come up with this type of resolution. This is an unprecedented starting point for further discussion on this issue." ${ }^{784}$ In fact, one of the main reasons that Moose was chosen as chief of police for

\footnotetext{
780 Bernstein, “Police Officers March," C 01.

781 Maxine Bernstein, "Police Back Survey on Racial Profiling," The Oregonian, 11/2/2000, D 03.

782 Gwenda Richards Oshiro, "Portland-Area Police Chiefs Denounce Racist Auto Stops," The Oregonian, 4/9/1999, A 01.

783 Bernstein, "Police Back Survey on Racial Profiling," D 03.

784 Oshiro, "Portland-Area Police Chiefs Denounce," A 01.
} 
Montgomery County was due to "his leadership in working to stop racial profiling."785 The organizers of the NOBLE conference acknowledged the gravitas of racial profiling by law enforcement, and also recognized Moose's ground breaking initiatives to curb this practice.

Why did Moose organize this conference? As a professional in an executive position, hosting a national conference and being hands-on in an organization that he had been so involved with, would be a huge step in his professional development. Organizing a conference is not an easy task, especially one of national scope. For an upwardlymobile, career-focused professional, this was a major accomplishment to have on one's resume.

In addition, Moose was giving back to NOBLE. As we can see from Moose's dedication to the children of Northeast Portland, he was cognizant of the value of being a role model to those communities. Surely Moose was modeling to young, black professionals how to give back to a professional association. Through his enrichment of labor and his management oversight, he was able to contribute to NOBLE, and have young black police officers from across the nation benefit from his experience. NOBLE was able to use him as an illustration and a role model for their professional development. This was similar to Moose's commitment to the SMART Reading Program and Uhuru Sa Sa prison group, but at a national level, and with his peers. The black professionals who were

\footnotetext{
785 Maxine Bernstein, “Police Chief Looks Forward To Challenges In Maryland," The Oregonian, 5/29/1999, A 01.
} 
impacted by Moose's contributions were going back to their bureaus, their precincts, all across the nation, and then affecting their communities. Moose was the shining example for black law enforcement officers, and a blue print for career progression and commitment to the community. Moose was an archetype to emulate for black police officers.

Moose also knew that being honored by the national organization was a vindication of sorts in terms of his relationship with segments of the Portland community. Many of Moose's detractors had not had the context to allow a comparison to other departments; they had no idea what a good job Moose had done with the Portland community. With crime going down in the Metro area, with Portland's leadership being recognized on the national stage for the development of community policing, with his public stance and commitment to resist racial profiling, Moose was an innovative and successful police executive. ${ }^{786}$ Many in Portland just did not see that. They saw the personnel reports and the outburst at the City Council. NOBLE made sure that Moose received the recognition that he deserved, o $\mathrm{n}$ a national scale, no less.

And, finally, Moose was able to showcase to Portland's black community that there were officers of color across the nation, professional men and women who had devoted

\footnotetext{
786 During Moose's tenure as chief, violent crime incidents in Portland decreased from 55,804 in 1994 to 46,788 in 1998. Whitney Strensrud, "Moose and the Bureau Graphic," The Oregonian, 7/28/1999, A15. In 1993, the number of "Citizens who feel safe/very safe at night" was listed by the PPB at 37\% - by 1999 , this number had increased to $51 \%$. The number of citizens who had a good or very good rating of the police was at 70\% in 1994, and had grown to $71 \%$ in 1999 (down from 73\% in 1998). City Club of Portland, "Community Policing in Portland," Portland, Oregon, 2003, Pg. 45.
} 
their lives to policing, and who also respected Moose. This was role modeling for Moose, as the NOBLE attendees marched through Northeast Portland, proud of their professional achievements and proud of the contributions that their members had given in serving their communities across the county. Moose was certainly aware of the impression that he wanted to leave with the black residents of Portland: black police officers exist, and they are doing good things in their disparate communities. This was not unusual. Change could happen in Portland, as it had across the nation.

In the Portland Police Bureau's August 12, 1999 newsletter, The Bulletin, a bold, black headline proclaimed "NOBLE Conference a success." The author of the brief article, Sgt. Dorothy Elmore, stated that the conference was successful "due to the many Bureau members who volunteered and supported the event." ${ }^{787}$ Sgt. Elmore added that "participants and the National NOBLE organization rank Portland's conference as the best ever."788 It was truly a crowning achievement on Moose's long career in Portland.

787 City of Portland Archives, B/030229, 24-03-36, Subject Files, Police: Mayor's Office, 1993-1998, Box 2, file "The Bulletin," Dorothy Elmore, "NOBLE conference a success," The Bulletin, 8/12/1999.

788 City of Portland Archives, "NOBLE conference a success," 8/12/1999. 


\section{Chapter 8 - Conclusion}

"[Moose's] philosophy, the bureau's philosophy, is to have a partnership with the community." 789

-PPB Public Information Officer CW Jensen, 1995

On June 28, 1999, Governor John Kitzhaber declared it “Chief Charles A. Moose Day" in Oregon. ${ }^{790}$ The Oregon Association of Chiefs of Police bestowed on Moose their President's Award to recognize "his work in reaching out to community members and promoting a diverse police force." ${ }^{\prime 791} \mathrm{~A}$ bit of fanfare was orchestrated as Charles Moose was about to leave town, but any tears that were shed surely must have been crocodile ones.

The NOBLE conference was one of Moose's last duties as Portland police chief. Within days, he was heading up a new department, across the nation in Maryland. Oregonian reporter Maxine Bernstein wrote of the hire that, "Montgomery County leaders, seeking to repair racial tension between the community and police after two fatal police shootings of unarmed African American men [by white officers], recruited Moose to lead the 1,200 member force." 792 Moose, in other words, was recruited to help save race relations in Montgomery County. The man who was viewed by many as a failure for his healing program in Portland was approached by Montgomery County specifically due

\footnotetext{
789 Tom Hallman Jr., "The Cop Behind The Sound Bite," The Oregonian, 1/8/1995, L 01.

790 Maxine Bernstein, "Governor Gives Moose A Special Day," The Oregonian, 6/29/1999, B 02.

791 Bernstein, "Governor Gives Moose," B 02.

792 Maxine Bernstein, "Police Chief Accepts Job In Maryland," The Oregonian, 5/28/1999, A 01.
} 
to the talents and experience that he could bring them. The Maryland county said that it was Moose's "embrace of community policing and his leadership in working to stop racial profiling as attributes that attracted them."793

Was Portland just not ready for Charles Moose? Moose had been selected to represent the changing, increasingly diverse Portland Police Department. Yet as chief, Moose attracted very public and very vocal criticism from nearly all corners. He had successfully expanded community policing, but Portlanders were never able to get past his outbursts and his race, and thus lost an opportunity. Obviously, the Montgomery County hiring committee was aware of Portland's public perception of the candidate Moose. But here he was being hired for attributes and ideas that drew so much fire in Portland, Oregon.

Montgomery County Executive Douglas M. Duncan seemed to wholeheartedly disagree with Portland's take on Moose's tenure. "Throughout the five-month nationwide search, Charles Moose's name surfaced time and time again as someone who possesses effective leadership skills within a large, diverse metropolitan police department."794 This is exactly the "skill set" that Moose possessed, and was selected for, in Portland. Yet he was also being admonished for a failure to exhibit those same attributes here in Portland. Why was there such a disconnect?

\footnotetext{
793 Maxine Bernstein, “Police Chief Looks Forward To Challenges In Maryland," The Oregonian, 5/29/1999, A 01.

${ }^{794}$ Bernstein, "Police Chief Accepts Job," A 01.
} 
Immediately after his announcement that he was leaving, the broadsheets and other pundits reviewed Moose's career and came to a bit of a mixed consensus. Maxine Bernstein of the Oregonian described Moose's time as chief as a "tumultuous tenure" that was "marked by stormy relations with the community and the mayor." 795 Former president of the Portland Police Association, Leo Painton, felt that Moose "lost a lot of credibility because of his anger."796 But Painton was somewhat sympathetic towards Moose. He felt that "part of Moose's problems was he was frustrated with his boss - his hands were tied. The mayor's the police commissioner, after all." ${ }^{797}$ Editors at The Oregonian were straight forward when they declared that "an explosive temper sometimes set back Moose's efforts and severely bruised some relationships," but the paper cautioned that "the chief should be remembered less for those occasional outbursts than for his huge accomplishments."798

In the immediate wake of his announcement, Moose looked back on his legacy in a fairly positive manner. In July 1999 he said, "To make it to chief in your own department was an incredible feeling. No matter what went wrong, you can never take away the fact

\footnotetext{
795 Bernstein, "Police Chief Accepts Job," A 01. In "a low point" in their relationship, Moose and Katz battled after anticipated budget cuts that led to hiring freezes. Moose hired new staff anyways, and he and the mayor clashed. "He knew that he didn't have the authority to do what he did. And he did it anyway," Katz claimed. Moose responded that, "I guess I should have stood and saluted. That would have been a more mature response." David Anderson, "Portland's Top Cop Under Fire From His Own Force," The Oregonian, 10/26/1997, A01.

796 Bernstein, "Police Chief Accepts Job," A 01.

797 Bernstein, "Police Chief Accepts Job," A 01.

798 Editorial, "Chief Was Never Milquetoast," The Oregonian, 5/28/1999, D 14.Moose's accomplishments in Portland included achieving a lower violent crime rate, securing \$26.6 million dollars in federal and state grants, working to bring an end to racial profiling in Oregon and hiring more officers (953 in 1993 vs. 1,029 in 1999) who were more educated and more diverse than previous hires. Whitney Strensrud, "Moose and the Bureau Graphic," The Oregonian, 7/28/1999, A15.
} 
that in Portland's history, I'm chief. When you look at the pictures on the wall of the chiefs, l'Il be there with an elite group. That feels good."799

Race was absolutely on his mind when he considered his legacy. Moose said "You have to understand, as an African American male, when someone says they want you to come and to take responsibility for a community, and that they trust you to do that... People don't say that to me very often. So you have to understand, when people want you to do something, what a tremendous compliment that is." 800

Maxine Bernstein expanded a bit on Moose's reflections and wrote that, "He hopes he will be remembered for listening to officers' and residents' ideas and turning them into viable programs to meet their needs." Moose agreed, stating "when people presented ideas, they didn't fall into a black hole. I think I was responsive to them and to the community. I would hope that would be the reputation I've left." 801

Moose was flawed and perhaps he knew it most of all. In late May 1999, at his going away ceremony at Iris Court, Moose said, "As a man who tries to reach his potential, there are times when what I do absolutely disgusts me, but there are also times when what I do impresses me tremendously." ${ }^{802}$ Moose undeniably tried to modify how he interacted with others, but yet he did not want those previous, sour interactions to be

\footnotetext{
799 Maxine Bernstein "Moose Closes Out 6-Year Tenure of Achievement, Pitfalls as Chief," The Oregonian, 7/28/1999, A 01.

800 Bernstein, "Police Chief Looks Forward," A 01.

${ }^{801}$ Bernstein, "Moose Closes Out 6-Year Tenure," A 01.

802 Bernstein, "Police Chief Looks Forward," A 01.
} 


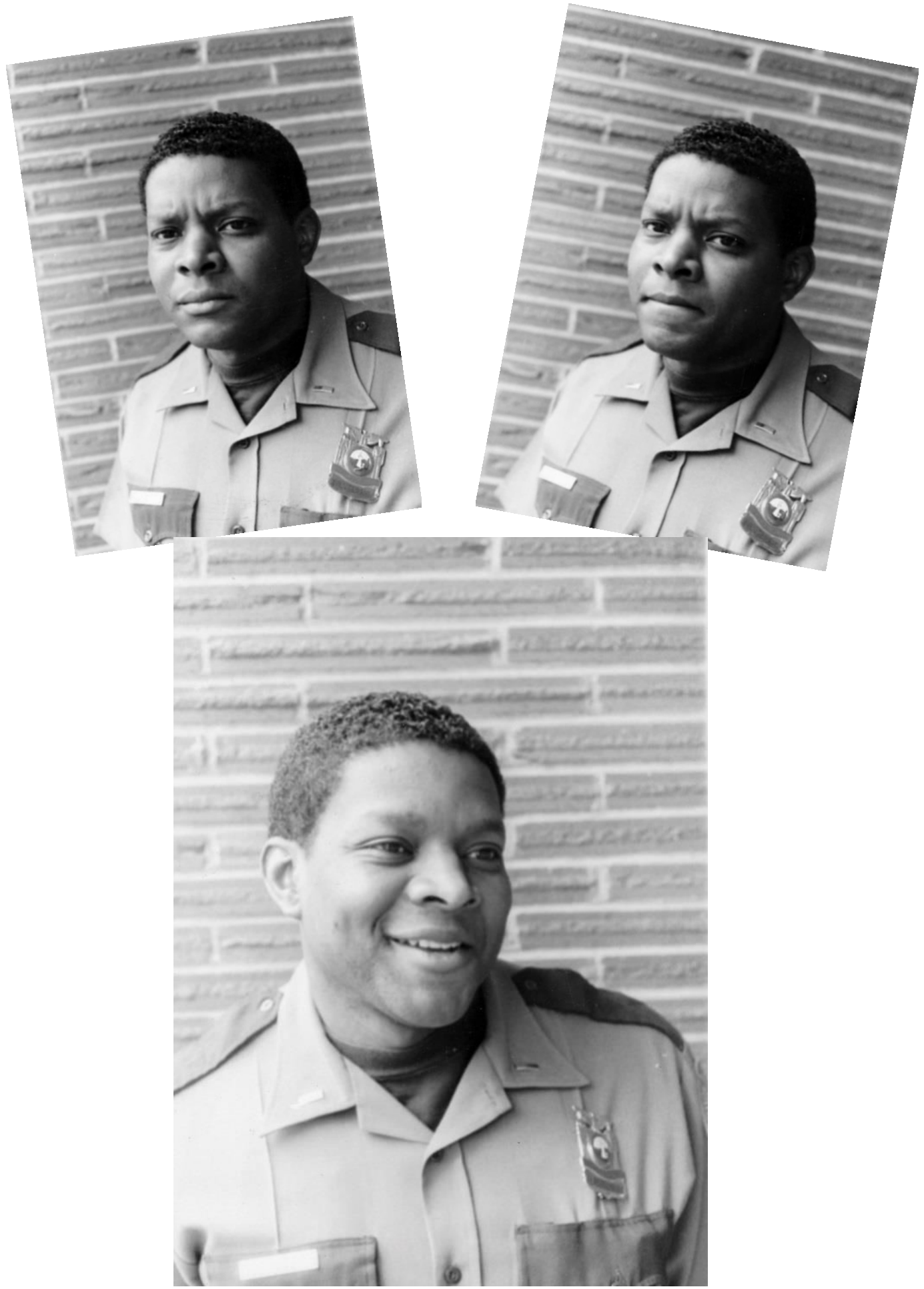

Figure 17 A tryptic of Moose.

Courtesy of the Oregon Historical Society, Images bb013827-29 
forgotten. Moose kept his anger issue reprimands in his personnel file when he could have gotten rid of them as reminders of where he had slipped or stumbled, so he could see where he needed to grow.

At his May 1999 farewell, Moose tried to say why he was leaving. What he needed, he said, was a new challenge. Particularly revealing was his comment that "I'm familiar with the issues and problems of Portland. We're always looking for different approaches to solve those problems, but they don't really change that much." ${ }^{804}$ In his book, Moose offered another interpretation for his leaving - but this one was a little more visceral, and quite introspective. "I also had a weird notion that somehow I'd lucked into the breaks I'd gotten in Portland, and I wondered if I could cut it in a different environment. I wondered if I'd be good enough to make it in another city." 805 This was a very introspective moment from a career police administrator who rose to the top of his bureau through hard work and a much lengthier career path than a white police officer might have faced.

Surely Moose wrestled with his legacy. As an undergraduate student at University of North Carolina, Chapel Hill, Moose had studied American History. He understood that historians are the ones who decide one's legacy. Maybe there was a hint of that desire to steer the evaluation, but Moose was defiant in his last address to the City Club of

\footnotetext{
${ }^{804}$ Bernstein, "Police Chief Looks Forward," A 01.

${ }^{805}$ Charles Moose and Charles Fleming, Three Weeks In October; The Manhunt For The Serial Sniper, (Waterville, Maine: Thorndike Press, 2004), 417.
} 
Portland on July, 23, 1999. He was proud of the fact that he had lowered crime over his tenure as chief, while the population of Portland had risen. "But still there are some that will say 'So What?,'” was a constant refrain in his speech. "People in Portland like to know 'What have you done for me lately? What have you done that's special?"'806 In his speech, Moose also looked beyond just crime and law enforcement, just as his community policing had looked at a community with a more holistic approach. Moose talked about larger, state-level issues in his speech. He took to task the Governor and his threats to veto a bill with funding for local schools: "It is absolutely insulting to go around the nation, and have people hear and understand the dilemmas that we have about educating our children. And we're generally at some conference pretending that we're innovative and progressive, and that we cared about the future. And then they read about what we're doing to our school kids. Very strange message." 807 He even seemed to admonish the elite City Club attendees as "you folks, you people" when speaking of the lack of affordable housing for immigrants. "I'm not talking about where you live. I'm sure everyone in this room is doing just fine." 808

Moose tried to change the lives of black residents in Portland. Ultimately, in this very white city, he faced harsh criticism at nearly every turn. He brought a great deal of expectation to his appointment. His was a political posting that was based somewhat on

${ }^{806}$ City Club of Portland, "The State of Portland Police." 7/23/1999. https://www.youtube.com/watch?v=SXLLTs81WPE\&feature=youtu.be ${ }^{807}$ City Club of Portland, "The State of Portland Police." 7/23/1999.

${ }^{808}$ City Club of Portland, "The State of Portland Police." 7/23/1999. 
his race, and the hope that he could bring further diversity to the Portland Police Bureau.

Some of Moose's strongest and most visible critics were found in Portland's black community - or even the community as a whole. Moose had worked his entire career in Portland with the mindset of changing this community for the better. He wanted to provide better housing, better nutrition, more educational opportunities, and assist people in finding better jobs. These are areas one does not typically associate with "policing," yet Moose was always cognizant of how he could improve the lives of Portland's black residents. Yet these very citizens were sometimes not very appreciative of his attempts to improve their standard of living. Portland Police Officer Victoria Wade was quoted in the Jackson (Mississippi) Advocate as saying that "Moose was in good standing with 'Portland's high-ranking whites,' but that he had little support among blacks." 809

Despite the compelling story of struggles he had faced to advance to a very successful career at a high level, Moose was embittered by his tenure as chief. In his book he wrote, "I don't think there was any gaping hole in Portland society when I left." ${ }^{810} \mathrm{He}$ realized he was a "controversial" figure in Portland, and that there was "animosity" when he moved on. ${ }^{811}$

${ }^{809}$ As quoted in Rachel Zimmerman, “Guess Who's Coming To Power?" Willamette Week, 7/227/28/1993, 14.

${ }^{810}$ Moose and Fleming, Three Weeks In October, 577.

${ }^{811}$ Moose and Fleming, Three Weeks In October, 578. 
Portland as a whole missed an opportunity with Moose's departure to Maryland. The citizens of Portland seemed unable to look past Moose's outbursts, and maybe even unable to move beyond that entrenched racism that Oregon was built upon. Portland had an opportunity to keep Moose's framework of community policing active and thriving in the community. But an examination of the bureau's website finds the term "community policing" relegated to historical documents and pdfs; it does not seem to be a priority for the current bureau. ${ }^{812}$ The racial make-up of the officers of the Portland Police Bureau is still overwhelmingly white, with a 2012 report finding the racial composition of officers on the bureau to be only four percent black, four percent Hispanic, and six percent Asian. ${ }^{813}$ Indeed, Portland missed an opportunity two decades ago to participate in a meaningful discussion of race and racism and have those conversations guided by an engaged, educated, and thoughtful leader. ${ }^{814}$ As controversial as his tenure was, Moose provided Portlanders with these opportunities to

${ }^{812}$ Community Policing Strategic Five Year Plans ended in 2012, it would seem... See https://www.portlandoregon.gov/police/article/196743 Accessed online, 6/27/2016.

${ }^{813}$ Carli Brosseau, "Portland has fewer police officers per resident than other big cities, data show," The Oregonian, 5/19/2015. Accessed online, 6/27/2016 http://www.oregonlive.com/portland/index.ssf/2015/05/portland has fewer_police_offi.html Is diversity of officers a desired development for a police force? A recent study suggests that it could benefit communities. Sociologist Joscha Legewie of New York University's research found that "diverse police departments are particularly able to alleviate tensions in cities... where you have preexisting racial, ethnic tensions." Max Ehrenfreund, "Study: Fewer black civilians are killed by police in cities with more black officers," The Washington Post, 5/25/2016. Accessed online, 11/18/2016. https://www.washingtonpost.com/news/wonk/wp/2016/05/25/study-fewer-black-civilians-are-killed-bypolice-in-cities-with-more-black-officers/

${ }^{814}$ After a June 1996 arson at a black church, Immanuel Christian Fellowship, 311 N. Ivy Street, (which initially was suspected to be racially motivated), Chief Moose said, "the only way we'll eradicate racism is by talking about it and addressing this issue. If there's anything good about this, it's that it gives us a chance to develop strategies to overcome racism." Brian Meehan, "Church-Burning Horror Reaches Into Portland The Arson," The Oregonian, 6/21/1996, A 01. 
decide how they wanted to be policed, but it was much easier to focus on his emotional outbursts and public missteps when assessing his successes or failures.

Moose himself felt somewhat ambivalent about his legacy as he was preparing to leave. As reporter Maxine Bernstein wrote at the time: “Moose said he can't control what people say or write about him. But he had one wish: "I just hope that behind my name it will say, comma, former Portland police officer. If it says that, then I know they'll know who I am.'"'815

815 Maxine Bernstein, “Outgoing Chief Urges Everyone to Take Part," The Oregonian, 7/24/1999, D 01. 


\section{Bibliography}

ABC News, World News Saturday, 11/27/1993.

Alexander, Nanine. "Black Leaders Rate Katz's Credibility." The Oregonian, 6/24/1993, C 08.

Anderson, David R. "Financial Practices Of Police Draw Fire." The Oregonian, 5/9/1997, C 11.

Anderson, David. "Police Chief Faces The Heat." The Oregonian, 4/20/1997, D 01.

Anderson, David. "Portland's Top Cop Under Fire From His Own Force." The Oregonian, 10/26/1997, A 01

“Crime in America," CBS Evening News, CBS News broadcast, 11/22/1993.

Anderson, David and Trujillo, Laura. "Moose Opens Book On Four Disciplinary Incidents In His File." The Oregonian, 4/26/1997, 01.

Austin, David. "Man Who Led Protest In 1998 Is Found Shot." The Oregonian, 12/15/2003, B 07.

Badger, Emily. "How the whitest city in America appears through the eyes of its black residents." The Washington Post, 3/24/2015. Accessed online, 2/9/2016. https://www.washingtonpost.com/news/wonk/wp/2015/03/24/how-the-whitest-cityin-america-appears-through-the-eyes-of-its-black-residents/ Bella, Rick. "Unexplained, Unexpected Shows of Riot Squad Force Unwanted." The Oregonian, 7/24/1993, B 03. 
Blackford, Mansel G. “Civic Groups, Political Action, and City Planning in Seattle, 18921915." Pacific Historical Review 49 (1980): 557-580.

Boag, Peter. Same Sex Affairs: Constructing and Controlling Homosexuality in the Pacific Northwest. Berkley: University of Cailf. Press, 2003.

Bernstein, Maxine. “Black Police Conference Starts Today." The Oregonian, 7/24/1999, D 06.

Bernstein, Maxine. "Governor Gives Moose A Special Day." The Oregonian, 6/29/1999, B 02.

Bernstein, Maxine. "Moose Closes Out 6-Year Tenure of Achievement, Pitfalls as Chief." The Oregonian, 7/28/1999, A 01.

Bernstein, Maxine. "Moose Expounds On His Controversial Criticisms." The Oregonian, 11/20/1998, A 01.

Bernstein, Maxine. "Moose Lashes Out At Beanbag Critics." The Oregonian, 11/19/1998, A 01.

Bernstein, Maxine. "Outgoing Chief Urges Everyone to Take Part." The Oregonian, 7/24/1999, D 01.

Bernstein, Maxine. "Police Back Survey on Racial Profiling." The Oregonian, 11/2/2000, D 03.

Bernstein, Maxine. "Police Chief Accepts Job In Maryland." The Oregonian, 5/28/1999, A 01. 
Bernstein, Maxine. "Police Chief Looks Forward To Challenges In Maryland." The Oregonian, 5/29/1999, A 01.

Bernstein, Maxine. "Police Chief Resigns." The Oregonian, 5/27/1999, A 01.

Bernstein, Maxine. "Police Officers March For A Noble Cause." The Oregonian, 7/29/1999, C 01.

Bernstein, Maxine. “Report Due Today On Police Use Of Less-Lethal Guns Against Crowd." The Oregonian, 11/18/1998, B 05.

Black Lives Matter. "About the Black Lives Matter network." accessed 3/31/2016 http://blacklivesmatter.com/about/

Boykoff, Jules and Gies, Martha. "We're going to defend ourselves": The Portland Chapter of the Black Panther Party and the Local Media Response." Oregon Historical Quarterly 111 (2010): $278-311$.

Brosseau, Carli. "Portland has fewer police officers per resident than other big cities, data show." The Oregonian. 5/19/2015. Accessed online, 6/27/2016

City Club of Portland, “Community Policing in Portland," Portland, Oregon, 2003.

City Club of Portland. “New Directions For Portland's Police Department." 8/6/1993. https://www.youtube.com/watch?v=eP1UXxiVBqo\&feature=youtu.be

City Club of Portland. "The State of Portland Police." 7/23/1999. https://www.youtube.com/watch?v=SXLLTs81WPE\&feature=youtu.be City of Portland Archives, A2005-004, 0252-01, Mayor Vera Katz Subject Files, Internal Staff Files: Chuck Bolger, 1998-1999, Box 2, file "Constituent letters to Chief of Police 
Charles Moose," letter from Chief Moose to Denny West, Housing Authority of Portland, 7/20/1994.

City of Portland Archives, A2005-004, 0252-01, Mayor Vera Katz Subject Files, Internal Staff Files: Chuck Bolger, 1998-1999, Box 2, file "Constituent letters to Chief of Police Charles Moose," letter from Thomas E Kearns, 11/20/1998.

City of Portland Archives, A2005-004, 0252-01, Mayor Vera Katz Subject Files, Internal Staff Files: Chuck Bolger, 1998-1999, Box 2, file “Constituent letters to Chief of Police Charles Moose," letter from Sandra Golden, 11/20/1998.

City of Portland Archives, A2005-004, 0252-01, Mayor Vera Katz Subject Files, Internal Staff Files: Chuck Bolger, 1998-1999, Box 2, file “Constituent letters to Chief of Police Charles Moose," letter from Walter Morris Jr., 11/19/1998.

City of Portland Archives, A2005-004, 0252-01, Mayor Vera Katz Subject Files, Internal Staff Files: Chuck Bolger, 1998-1999, Box 2, file "Constituent letters to Chief of Police Charles Moose," letter from Tim Rich and Julia Spence of Neil Kelly, 6/23/1994.

City of Portland Archives, A2005-004, 0252-01, Mayor Vera Katz Subject Files, Internal Staff Files: Chuck Bolger, 1998-1999, Box 2, file “Constituent letters to Chief of Police Charles Moose," letter from Chief Moose to Tim Rich and Julia Spence of Neil Kelly, 7/7/1994.

City of Portland Archives, A2005-004, 0252-01, Mayor Vera Katz Subject Files, Internal Staff Files: Chuck Bolger, 1998-1999, Box 2, file "Constituent letters to Chief of Police 
Charles Moose," letter from Chief Moose to Denny West, Housing Authority of Portland, 7/20/1994.

City of Portland Archives, A2005-004, 0252-01, Mayor Vera Katz Subject Files, Internal Staff Files: Chuck Bolger, 1998-1999, Box 2, file "Constituent letters to Chief of Police Charles Moose," letter from Gordon Bussey, 11/30/1998.

City of Portland Archives, A2005-004, 0252-01, Mayor Vera Katz Subject Files, Internal Staff Files: Chuck Bolger, 1998-1999, Box 2, file “Constituent letters to Chief of Police Charles Moose," letter from Melvin Cearley, 11/23/1998.

City of Portland Archives, A2005-004, 0252-01, Mayor Vera Katz Subject Files, Internal Staff Files: Chuck Bolger, 1998-1999, Box 2, file “Constituent letters to Chief of Police Charles Moose," letter from Carol Heacock, 11/19/1998.

City of Portland Archives, B/006879, Chief's Office Files, “Gay Pride Parade/Saturday July 9, 1994, 12:00pm, Memo 6/30/1994."

City of Portland Archives, B/030042, 40-12-40, Subject Files, Mayor Katz, Sam Adams Police-Public Correspondence, Executive Orders, Campaigns, 1997-1998. Letter from Joyce Nelson to Mayor Vera Katz, 10/26/1997.

City of Portland Archives, B/030226, 24-02-15, Subject Files, Police: Mayor's Office, 1993-1996, Police Related Press Releases/Video Tapes, file “April - Aug 1996," “Portland Police Chief Charles Moose To Host National Organization Of Black Law Enforcement Executives (NOBLE), Northwest Chapter Officers Installation Dinner," 5/24/1996. 
City of Portland Archives, B/030226, 24-02-15, Subject Files, Police: Mayor's Office, 1993-1996, Police Related Press Releases/Video Tapes, file “April - Aug 1996," “Portland Police Chief Charles Moose To Host National Organization Of Black Law Enforcement Executives (NOBLE), Northwest Chapter Officers Installation Dinner," 5/24/1996.

City of Portland Archives, B/030226, 24-02-15, Subject Files, Police: Mayor's Office, 1993-1996, Police Related Press Releases/Video Tapes, file “Jan-March 1994 News Release" "Chief Moose, Officers Capture Suspect In Gang Related Shooting," 3/25/1994. City of Portland Archives, B/030226, 24-02-15, Subject Files, Police: Mayor's Office, 1993-1996, Police Related Press Releases/Video Tapes, file "Jan-March 1994 News Release" “Letter to Atty Gen Reno from Charles Moose," 9/16/1994. City of Portland Archives. B/030229, 24-03-36, Subject Files, Police: Mayor's Office, 1993-1998, Box 2, file "The Bulletin," Dorothy Elmore, "NOBLE conference a success." The Bulletin, 8/12/1999.

City of Portland Archives, B/030226, 24-02-15, Subject Files, Police: Mayor's Office, 1993-1996, Police Related Press Releases/Video Tapes, file “Police - No Response Letters," Letter from David Gray to Mayor Katz, 4/23/1997. City of Portland Archives, B/030226, 24-02-15, Subject Files, Police: Mayor's Office, 1993-1996, Police Related Press Releases/Video Tapes, file “11/1994 - May 1995 News Releases," "Chief Moose Leads Northeast Portland In Walk For Humanity," 5/5/1995. 
City of Portland Archives, B/030226, 24-02-15, Subject Files, Police: Mayor's Office, 1993-1996, Police Related Press Releases/Video Tapes, file “July - Oct," “Chief Moose Withdraws Name From Consideration For Crime Bill Position," 9/16/1994.

City of Portland Archives, B/030226, 24-02-15, Subject Files, Police: Mayor's Office, 1993-1996, Police Related Press Releases/Video Tapes, file “11/1994 - May 1995 News Releases," “Program Seeks To Encourage "Police At Home” In Selected Portland Neighborhoods," 2/6/1995.

City of Portland Archives, B/030226, 24-02-15, Subject Files, Police: Mayor's Office, 1993-1996, Police Related Press Releases/Video Tapes, file "11/1994 - May 1995 News Releases," "Program Seeks To Encourage "Police At Home” In Selected Portland Neighborhoods," 7/25/1994.

City of Portland Archives, B/030226, 24-02-15, Subject Files, Police: Mayor's Office, 1993-1996, Police Related Press Releases/Video Tapes, file "July-Oct," “Moose, Kitzhauber To Meet Behind Closed Doors (Patrol Car Doors)," 7/25/1994.

City of Portland Archives, B/030226, 24-02-15, Subject Files, Police: Mayor's Office, 1993-1996, Police Related Press Releases/Video Tapes, file “11/1994-May 1995 News release," "Chief Charles Moose To Receive FBI Reward," 1/12/1995.

City of Portland Archives, B/030229, 24-03-36, Subject Files, Police: Mayor's Office, 1993-1998, Box 2, file “The Bulletin," “Chief's Corner," The Bulletin, 2/27/1997. City of Portland Archives, B/030229, 24-03-36, Subject Files, Police: Mayor's Office, 1993-1998, Box 2, file "The Bulletin," “Chief's Corner," The Bulletin, 6/5/1997. 
City of Portland Archives, B/030229, 24-03-36, Subject Files, Police: Mayor's Office, 1993-1998, Box 2, file "The Bulletin," "Special Supplement: Police at Home," The Bulletin, 2/11/1999.

City of Portland Archives, B/030229, 24-03-36, Subject Files, Police: Mayor's Office, 1993-1998, Box 2, file “The Bulletin," “Chief's Corner," The Bulletin, 8/27/1998.

City of Portland Archives, B/030229, 24-03-36, Subject Files, Police: Mayor's Office, 1993-1998, Box 2, file “The Bulletin," “Chief's Corner," The Bulletin, 9/10/1998.

City of Portland Archives, B/030229, 24-03-36, Subject Files, Police: Mayor's Office, 1993-1998, Box 2, file "The Bulletin," “Chief's Corner," The Bulletin, 10/24/1996.

City of Portland Archives, B/030042, 40-12-40, Subject Files, Mayor Katz, Sam Adams Police-Public Correspondence, Executive Orders, Campaigns, 1997-1998. Letter from Savilla Tabor to Mayor Vera Katz, 4/28/1997.

City of Portland Archives, B/030042, 40-12-40, Subject Files, Mayor Katz, Sam Adams Police-Public Correspondence, Executive Orders, Campaigns, 1997-1998. Letter from Mrs. Maxine Selling to Mayor Vera Katz, 7/15/1997.

City of Portland Archives, B/030042, 40-12-40, Subject Files, Mayor Katz, Sam Adams Police-Public Correspondence, Executive Orders, Campaigns, 1997-1998. Letter from Ken Betterton to Mayor Vera Katz, 5/20/1997.

City of Portland Archives, B/030042, 40-12-40, Subject Files, Mayor Katz, Sam Adams Police-Public Correspondence, Executive Orders, Campaigns, 1997-1998. Letter from David LaMarcha to Mayor Vera Katz, 4/30/1997 (received date -letter not dated.). 
City of Portland Archives, B/030042, 40-12-40, Subject Files, Mayor Katz, Sam Adams Police-Public Correspondence, Executive Orders, Campaigns, 1997-1998. Letter from Luciana Barberis to Mayor Vera Katz, 4/28/1997.

City of Portland Archives, B/030042, 40-12-40, Subject Files, Mayor Katz, Sam Adams Police-Public Correspondence, Executive Orders, Campaigns, 1997-1998. Letter from FG Williams to Mayor Vera Katz, 4/29/1997.

City of Portland Archives, B/030042, 40-12-40, Subject Files, Mayor Katz, Sam Adams Police-Public Correspondence, Executive Orders, Campaigns, 1997-1998. Letter from Anonymous to Mayor Vera Katz, 4/28/1997.

City of Portland Archives, B/030042, 40-12-40, Subject Files, Mayor Katz, Sam Adams Police-Public Correspondence, Executive Orders, Campaigns, 1997-1998. Letter from Mayor Vera Katz to Savilla Tabor, 5/20/1997.

City of Portland Archives, B/030042, 40-12-40, Subject Files, Mayor Katz, Sam Adams Police-Public Correspondence, Executive Orders, Campaigns, 1997-1998. Letter from Joyce Nelson to Mayor Vera Katz, 10/26/1997.

City of Portland Archives, Box 26-04-17, "Office of Mayor Vera Katz, Policy \& Historical Records, General Files - Police," "Mayor-Chief Meeting Summaries, March 12, 16 and 23, 1999."

City of Portland Archives, NOBLE Collection, File: 1999 NOBLE Conference, Committee Timelines, “Memorial March Organizational Timeline." 
City of Portland Archives, NOBLE Collection, File: 1999 NOBLE Conference, Committee Timelines, "Fundraising."

City of Portland Archives, NOBLE Collection, File: 1999 NOBLE Conference, Committee Timelines, "List Of Local Noble Sponsors."

City of Portland Archives, NOBLE Collection, File: 1999 NOBLE Conference, Committee Timelines, "Northwest Noble Conference Fundraiser Lunch, 2/26/1999."

City of Portland Archives, Official Minutes, City of Portland Council Meeting, $11 / 18 / 1998$.

City of Portland, Office of Neighborhood Associations, Neighborhood Social Profiles (1990 Census), King Neighborhood. City of Portland website. Accessed 10/13/2015. City of Portland Census Records https://www.portlandoregon.gov/oni/article/58046 (DOC 10/13/2015) https://www.portlandoregon.gov/oni/article/328525 2000 and 2010 Census Profile pdf, City of Portland website, accessed 10/13/2015. https://www.portlandoregon.gov/oni/article/375918

“Community Policing: Ten Years of Partnerships." Portland Police Bureau 1999 Statistical Report. Accessed online 4/15/2016.

https://www.portlandoregon.gov/police/article/29800

“Crime in America." CBS Evening News, CBS News broadcast. 11/22/1993.

“Current Notes." Journal of Criminal Law and Criminology, 37 (1946): 66-67.

Danks, Holly. “An Inevitable Clash of Ideologies." The Oregonian, 7/20/1993, A 01 
Danks, Holly. “Moose Buys Into The Bid To Take Back The Street.” The Oregonian, 11/10/1993, A 01.

Danks, Holly. "No Thanks, Chief." The Oregonian, 3/28/1994, B 01.

Danks, Holly and Manley, Paul. "Harsh discipline asked in T-shirt incident; $2^{\text {nd }}$ officer cited." The Oregonian, 4/30/1985, B 1.

Davidow, Bill. "Redlining for the $21^{\text {st }}$ Century." The Atlantic, 3/5/2014. Accessed online 12/18/2015. http://www.theatlantic.com/business/archive/2014/03/redlining-for-the-

\section{1st-century/284235/}

Dembo, Jonathan. “John Danz and the Seattle Amusement Trades Strike, 1921-1935." The Pacific Northwest Quarterly 71 (1980): 172-182.

Dodds, Gordon. Oregon; A Bicentennial History. New York: W.W. Norton \& Co., 1977. Dodds, Gordon. The College That Would Not Die; The First Fifty Years of Portland State University, 1946 - 1996. Portland: OHS Press, 2000.

Donnelly, Robert C. Dark Rose; Organized Crime \& Corruption in Portland. Seattle: UofW Press, 2011.

Duin, Steve. “Moose Copies Cat In The Hat." The Oregonian, 4/20/1997, D 01. Dupay, Don. Behind The Badge In River City. Portland: Oregon Greystone Press, 2015. Dunham Elisabeth, "Charles Moose, Portland police Chief, On His Comfy Living Room." Homes \& Gardens of the Northwest Special Home Style Edition, The Oregonian, 9/18/1997, 31.

Editorial. "Bridging Troubled Waters." The Oregonian, 2/28/2993, K 02. 
Editorial. "Calm In The Face Of Outrage." The Oregonian, 11/25/1988, C 06.

Editorial. "Chief Was Never Milquetoast." The Oregonian, 5/28/1999, D 14.

Editorial. "Hometown Police." The Oregonian, 8/13/1993, C 08.

Editorial. "Hometown Police." The Oregonian, 9/4/1996, E 08.

Editorial. "Revisit Portland Redlining." The Oregonian, 11/14/1993, D 01

Editorial. "Securing Troubled Housing." The Oregonian, 5/2/1994, B 06.

Editorial. "Welcome Home, Officer." The Oregonian, 2/14/1995, B 04.

Egan, Timothy. "To Stay in Touch With Crime, A Police Chief Moves Near It." The New York Times, 12/25/1993, Sec. 1, 6.

Ehrenfreund, Max. "Study: Fewer black civilians are killed by police in cities with more black officers," The Washington Post, 5/25/2016.

Ellis, Barnes C., "Moose Exhorts Portlanders To Keep Their City." The Oregonian, 8/7/1993, B 04.

Ellis, Barnes C., "Secrecy Shrouds National Search For Police Chief." The Oregonian, 5/13/1993, D 05.

Ellis, Barnes C., "Skinhead Violence Surges In Wake of Seraw Killing." The Oregonian, 12/24/1988, A 01.

Ellis, Barnes C. and Rollins, Michael. "Potter to Announce He's Retiring." The Oregonian, 3/10/1993, A 01.

Erickson, Steve. "'Pioneer Portland blacks recall bleak early years." The Oregonian, 3/30/1975, Pg. B 1 
Evangelista, Benny Jr. "Police admit opossum incident." The Oregonian, 3/15/1981, B 7. Evangelista, Benny Jr. "Police tale questioned by owner." The Oregonian, 3/16/1981, B 1.

Farrell, Peter. "Assessment Emerges Of Chance For Healing In Conflict's Aftermath." The Oregonian, 8/21/1998, B 01.

Farrell, Peter. "Police Disperse Protesters on MLK." The Oregonian, 8/18/1998, B 07.

Farrell, Peter. "Portland Takes A Bite Out Of Crime. " The Oregonian, 4/22/1996, B 02.

Farrell, Peter and Trujillo, Laura. "Meeting May Calm Protest Over Police Action At

Party." The Oregonian, 8/19/1998, A 01.

Farrell, Peter and Trujillo, Laura. "Protest Brings Differing Accounts." The Oregonian, 8/19/1998, A 01.

Federal Bureau of Investigation website, "A Byte Out Of History, Part 1." Accessed online 11/11/2015 https://www.fbi.gov/news/stories/2007/october/snipers 102207 Fentress, Aaron. "Loan Plan Urges Officers To Live in Target Areas." The Oregonian, 2/7/1995, B 01.

“Firings bring protest." The Oregonian, 3/31/1981, B 1.

Foxworth, Derrick. "After Action Report - Daniel Binns Annual Birthday Party, Northeast Precinct Planning and Response." Bureau of Police, Inter-Office Memorandum, 9/29/1998. Lisa Loving Collection.

Friedheim, Robert L. "The Seattle General Strike of 1919." The Pacific Northwest Quarterly 52 (1961): 81-98. 
Gage, Susan. "Moose Seeks Job As Chief In Capital." The Oregonian, 02/18/1998, A 01.

Gitlin, Todd. The Sixties, Years of Hope, Days of Rage. New York: Bantam Books, 1987. Green, Ashbel S. "Police, Youths Clash Downtown." The Oregonian, 7/19/1993, A 01. Hallman, Tom Jr. “Mr. Moose's Neighborhood: Children Know Portland's Police Chief As A Friend." The Oregonian, 1/19/1995, A 01

Hallman, Tom Jr. "Racial Murder Angers Portlanders." The Oregonian, 11/17/1988, B 02. Hallman, Tom Jr. "Rookies To Chief, Safety Comes First." The Oregonian, 11/14/1994, B 04.

Hallman, Tom Jr. "The Cop Behind The Sound Bite." The Oregonian, 1/8/1995, L 01.

Hallman, Tom Jr. "White-Supremacist Skinheads Termed Fastest Growing Hate Group In Nation." The Oregonian, 11/16/1988, B 03.

Hamburg, Ken. "Fired policemen's appeal could take several months." The Oregonian, 5/9/1985, D 2.

Hammond, Betsy. "In a changing world, Portland remains overwhelmingly white." The Oregonian, 1/17/2009. Accessed online 10/13/2015.

http://www.oregonlive.com/news/index.ssf/2009/01/in a changing world portland r. $\underline{\text { html }}$ Hannah-Jones, Nikole. "In Portland's heart, 2010 Census shows diversity dwindling." The Oregonian, 4/30/2011. Accessed online 3/31/2016. http://www.oregonlive.com/pacificnorthwest-news/index.ssf/2011/04/in portlands heart diversity dwindles.html 
Hoffman, Dennis E. and Webb, Vincent J. “Police Response to Labor Radicalism in Portland and Seattle, 1913-19." Oregon Historical Quarterly 87 (1986): 341-366. Home Forward website. http://www.homeforward.org/development/propertydevelopments/humboldt-gardens Accessed online 10/9/2015. Hoover, Erin. "Moose Drops Out of Cops Job Selection." The Oregonian, 09/17/1994, A 01. Hoover, Erin. "Standing on Principle." The Oregonian, 10/23/1994, A 01. Hylton, Dory. "The Portland State University Strike of May 1970: Student Protest as Social Drama." Ph.D. diss., University of Oregon, 1993.

J.R. (sic) “Another First Woman - Houston Police Chief.” Off Our Backs. 20 (1990): 5. Jacklet, Ben. "The Secret Watchers." The Portland Tribune, 9/12/2002. Accessed online 3/15/2016. http://portlandtribune.com/component/content/article?id=117580 Jacklet, Ben. "Watcher Files Find New Home." The Portland Tribune, 1/12/2004. Accessed online 3/15/2016.

http://portlandtribune.com/component/content/article?id=107945 Jenning, Steve. "2 ex-officers charge politics in firings." The Oregonian, 4/4/1981, A 13. Karol, Gayle. "Dec. 11, 1946: Almost the first black Portland police officer." The Oregonian, 12/05/2008. Accessed 5/20/2016.

http://www.oregonlive.com/ospecials/blackhistory/index.ssf/2008/02/dec 111946 al most the first b.html Langer, Elinor. A Hundred Little Hitllers. New York: Metropolitan Books, 2003. 
Lane, Dee. "Neighborhood Activists Blame Blight On Lenders." The Oregonian, 9/11/1990, A 01.

Lansing, Jewel. Portland: People, Politics and Power, 1851 - 2001. Corvallis: Oregon State University Press, 2005.

Lansing, Jewel and Leeson, Fred. Multnomah: The Tumultuous Story of Oregon's Most Populous County. Corvallis: Oregon State University Press, 2012.

“League Praises Jenkins' Action.” The Oregonian, 12/13 (15?) 1946, 21.

Learn, Scott. "New Police Priorities Set Out In Strategic Plan Get Approval By Council." The Oregonian, 10/3/1996, E 04.

Leeson, Fred. "Preserving The Precinct." The Oregonian, 3/30/1994, C 01.

LeWarne, Charles P. “The Bolsheviks Land in Seattle: The "Shilka" Incident of 1917."

Arizona and the West 20 (1978): 107-122.

Lewis, William G. "Toward Representative Bureaucracy: Blacks in City Police Organizations, 1975-1985." Public Administration Review 49 (1989): 257-68.

Loving, Lisa. “A Forgotten Riot That Rocked City Hall." The Skanner, 8/22/2014. Accessed online 5/25/2016. http://www.theskanner.com/news/northwest/21739-the-skannernews-archives-a-forgotten-riot-that-rocked-city-hall

Jeff Lyon, "Good Cop, Bad Cop." The Chicago Tribune, 3/9/1997. Accessed online 5/31/2016. http://articles.chicagotribune.com/1997-0309/features/9703090137 1 chicago-cops-slick-boys-bad-cop 
MacColl, Kimbark. Merchants, Money \& Power; The Portland Establishment. The Georgian Press, 1988.

Manley, Paul. "Police chief will send T-shirt disciplinary suggestion to Clark." The Oregonian, 5/7/1985, B 1.

Manzano, Phil. “Portland's Police Chief Moose On The Loose.” The Oregonian, 9/5/1993, C 01.

Manzano, Phil. "Moose Revamps Command Staff." The Oregonian, 6/21/1994, B 03. Manzano, Phil. "Moose Finalist to Head Project." The Oregonian, 9/11/1994, A 01. Manzano, Phil and Hogan, Dave. "Reno Tours Portland Chief's Neighborhood." The Oregonian, 6/14/1994, B 01.

Maves, Norm JR and Nkrumah, Wade. “Goin' North." The Oregonian, 10/17/1994, B 01. Mayer, James. "Shootings Leave 1 Dead, 1 Hospitalized." The Oregonian, 8/8/1993, Pg. C 07

McDevitt, Daniel S. and Field, Mark W. Police Chief: How to Attain and Succeed in This Critical Position. Springfield, IL: Charles C. Thomas, Publisher, 2010.

McElderry, Stuart. "Vanport Conspiracy Rumors and Social Relations in Portland, 1940 1950." Oregon Historical Quarterly 99 (1998): 134-163.

Meehan, Brian. "Church-Burning Horror Reaches Into Portland The Arson." The Oregonian, 6/21/1996, A 01.

Meehan, Brian. "New Anarchists Not Bomb-Throwers, Associates Say." The Oregonian, 7/20/1993, A 11. 
Moose, Charles. "The Theory and Practice of Community Policing: An Evaluation of the Iris Court Demonstration Project." PhD Diss., Portland State University, Studies, 1993. Moose, Charles and Fleming, Charles. Three Weeks In October; The Manhunt For The Serial Sniper. Waterville, Maine: Thorndike Press, 2004.

"Moose for Chief." The Portland Skanner, 5/5/1993, 4.

"Moose Releases Personnel Records in Advance of Suit." The Portland Skanner, 4/30/1997, 3.

Schultz, Dorothy Moses. Breaking the Brass Ceiling: Women Police Chiefs and their Paths to the Top. Westport, CT: Praeger Publishers, 2004.

Myers, Gloria. A Municipal Mother; Portland's Lola Greene Baldwin, America's First Policewoman. Corvallis: Oregon State University Press, 1995.

Munk, Michael. The Portland Red Guide: Sites \& Stories of Our Radical Past. Portland: Ooligan Press, 2007. NBC News, “America Close Up” segment, 6/2/1994.

“Negro Starts Police Duties." The Oregonian, 12/11/1946, 12.

Nicholas, Jonathan. "Seeking a Sense of Community? Take a Walk on the Wide Side." The Oregonian, 6/26/1994, L 03.

Nkrumah, Wade. "King Residents Bristle at Moose Remarks." The Oregonian, 11/20/1998, B 01.

Nkrumah, Wade. "Neighbors Show Range Of Opinion On Moose." The Oregonian, 5/28/1999, D 02. 
Nkrumah, Wade and Oshiro, Gwenda Richards. "Reaction to Moose Generally Favorable." The Oregonian, 11/21/1998, B 01.

Noakes, Greg. "Black Exclusion Laws in Oregon." Oregon Encyclopedia website. Accessed online 12/18/2015.

http://oregonencyclopedia.org/articles/exclusion laws/\#.VnROM krK70

Novak, Matt. "Oregon was Founded as a Racist Utopia." Gizmodo website. Accessed

online 11/15/2015. http://gizmodo.com/oregon-was-founded-as-a-racist-utopia-

\section{0}

“NOBLE $23^{\text {rd }}$ Annual Training Conference and Exhibition Preliminary Schedule."

Obtained from Valerie Shufford, Director of Conferences, NOBLE Natl Office, Alexandria, VA, 4/14/2015.

National Organization of Black Law Enforcement Executives webpage, History of Noble.

Accessed online 4/15/2016. http://www.noblenational.org/history.aspx

Noble Actions. Volume 98, Number 3, Fall 1998, 10.

“NOBLE Meets, Honors Moose." The Portland Skanner, 07/28/1999, 8.

Orr. "Operations Order: Party at Ditlers Beach (Broughten Beach) $43^{\text {rd }}$ and Marine Drive 081797 Sunday 1300-2100," Bureau of Police, Inter-Office Memorandum, 8/15/1997. Lisa Loving Collection.

O’Hagen, Maureen. “Black and White." Willamette Week, 5/7/1997, Pg. 14.

O’Hagen, Maureen. “Hope or Hype.” Willamette Week, 9/27-10/3/1995, 20.

O’Hagen, Maureen. “Internal Affairs." Willamette Week, 1/15/1997, 21. 
O'Hagen, Maureen. "Phone Tag." The Willamette Week, 4/30/1997, 14.

Oregon History Project website. "Luncheonette Sign, We Cater To White Trade Only." Accessed online 3/31/2016. http://oregonhistoryproject.org/articles/historicalrecords/luncheonette-sign-we-cater-to-white-trade-only/\#.Vv2YUOIrK70 Oshiro, Gwenda Richards. "Portland-Area Police Chiefs Denounce Racist Auto Stops." The Oregonian, 4/9/1999, A 01.

Painter, John JR. "Vancouver Police Try Beanbag Guns." The Oregonian, 11/24/1998, B 02.

Parker, Tonya Y. "Melee is Focus of Meeting." The Portland Skanner, 8/19/1998, 1.

Parker, Tonya Y. "Moose Lashes Out at Critics." The Portland Skanner, 11/18/1998, 1. Parks, Casey. "Welcome to My World: In America's whitest city, young blogger tries to prove the black middle class exists." The Oregonian, 11/9/2015. Accessed online $3 / 31 / 2016$. http://www.oregonlive.com/living/index.ssf/2015/11/welcome to my world blogger. $\underline{\text { html }}$

“Police Chief Sets Example For All." The Portland Skanner, 11/24/1993, 4.

Portland Police Bureau Record Request, June $5^{\text {th }} 1998$ letter from Charles Moose to Kathleen L. McChesney, Special Agent In Charge, FBI, Portland.

Portland Police Facebook page. "\#ThrowbackThursday Officer Charles H. Duke." Accessed online 4/5/2016. https://www.facebook.com/portlandpolice/posts/10151846906045904 
Portland Police Bureau website. "History of the Portland Police Bureau." Accessed online 1/28/2016. https://www.portlandoregon.gov/police/40004 Ratcliff, "Binns party scheduled for August $16^{\text {th }}$," Bureau of Police, Inter-Office Memorandum, 7/29/1998. Pg. 1. Lisa Loving Collection.

Rollins, Michael. "Asian-American Claims Bias As Police Promote Black." The Oregonian, 4/2/1991, В 03.

Rollins, Michael. "Cadets Focus on Portland Police Pitch." The Oregonian, 4/21/1990, D 01.

Rollins, Michael. "New Era of Community Policing Looms For Portland Force." The Oregonian, 9/30/1990, C 12.

Rollins, Michael. "Scrounging To Heal Wounds." The Oregonian, 9/27/1992, A 01. Rollins, Michael and Ellis, Barnes C. "Wanted: New Portland Police Chief." The Oregonian, 3/11/1993, A 16.

Rollins, Michael and Hallman, Tom Jr. "Potter Legacy Includes Divided Police Bureau." The Oregonian, 3/14/1993, A 01.

Rollins, Michael and Long, James. "Moose's Dedication Wins Katz." The Oregonian, 6/26/1993, A 01.

Rollins, Michael and Long, James. "Moose Will Command Police." The Oregonian, 6/26/1993, A 01.

Rollins, Michael and Wellington, Elizabeth. “Red-Clad Mourners Grieve Gang Leader's Death." The Oregonian, 8/17/1993, A 08. 
Rose, Kenneth D. "The Labbe Affair and Prohibition Enforcement in Portland." The Pacific Northwest Quarterly 77 (1986): 42-51.

Roth, Mitchel P. Crime and Punishment; A History of the Criminal Justice System.

Belmont, CA: Thompson Wadsworth, 2005.

Rubenstein, Sara. "Police Increase Patrols After Youth Killed, Another Wounded." The Oregonian, 8/9/1993, B 06.

Sardo, Jordana. "Letters To The Editor." The Portland Skanner, 9/2/1998, 4.

Schwantes, Carlos. The Pacific Northwest: An Interpretive History. Lincoln: University of Nebraska Press, 1996.

"Searching for Police Chiefs." Journal of Criminal Law and Criminology 32 (1941): 341342.

Shusta, R M; Levine, D R; Harris, P R; Wong, H Z. Multicultural Law Enforcement: Strategies for Peacekeeping in a Diverse Society. Upper Saddle River, NJ: Prentice-Hall, Inc, 1995. Accessed online, 4/14/2016.

http://wps.pearsoncustom.com/wps/media/objects/10774/11033223/CJ310 Ch02.pdf Stanford, Phil. Portland Confidential; Sex, Crime and Corruption in the Rose City, Portland: WestWinds Press, 2004.

Strensrud, Whitney, “Moose and the Bureau Graphic." The Oregonian, 7/28/1999, A 15.

“T-shirt sale backfires on policeman." The Oregonian, 4/27/1985, C 1.

"The Suspects Who Died." The Oregonian, 5/9/1985, D 2. 
Tracy III, Charles A. "Police Function in Portland, 1851-1874, Part. I." Oregon Historical Quarterly 80 (1979):

Tracy III, Charles A. "Police Function in Portland, 1851-1874, Part. II." Oregon Historical Quarterly 80 (1979): 134-169.

Tracy III, Charles A. "Police Function in Portland, 1851-1874, Part. III." Oregon Historical Quarterly 80 (1979):

Valdez, Angela. “After Hours; Inside Portland's Illegal Club Scene." Willamette Week, 4/19/2005. Accessed online 5/31/2016. http://www.wweek.com/portland/article-4319after-hours.html

Wing, Sage Van and Greenstone, Scott. "Are African-Americans Really Leaving Portland?" OPB's Think Out Loud, 5/17/2016. Accessed online, 5/20/2016 http://www.opb.org/radio/programs/thinkoutloud/segment/oregon-portland-africanamericans/

Walling, George W. Recollections of a New York Chief of Police. New York: Caxton Book Concern, 1887.

Williams, Brien R. Interviewer. “Oral History Interview, Charles A. Moose, 9/9/2012." National Law Enforcement Museum.

Williamson, Don. “King Neighborhood Needs Chief Moose, Many More.” The Oregonian, 12/6/1993, A 11.

Willis, Terry R. "The Black Hole of Seattle: The Socialist Free Speech Movement, 19061907." The Pacific Northwest Quarterly 91 (2000): 124-135. 
Zimmerman, Rachel. “Guess Who's Coming To Power?" Willamette Week, 7/227/28/1993, 16. 